Portland State University

PDXScholar

2016

Downtown Revitalized, Community Organized: a

Comparative Analysis of Tulsa, Oklahoma and

Portland, Oregon

Amber Wagoner

Portland State University

Follow this and additional works at: https://pdxscholar.library.pdx.edu/honorstheses

Let us know how access to this document benefits you.

Recommended Citation

Wagoner, Amber, "Downtown Revitalized, Community Organized: a Comparative Analysis of Tulsa, Oklahoma and Portland, Oregon" (2016). University Honors Theses. Paper 228.

https://doi.org/10.15760/honors.226

This Thesis is brought to you for free and open access. It has been accepted for inclusion in University Honors Theses by an authorized administrator of PDXScholar. Please contact us if we can make this document more accessible: pdxscholar@pdx.edu. 


\title{
DOWNTOWN REVITALIZED, COMMUNITY ORGANIZED: \\ A Comparative Analysis of Tulsa, Oklahoma and Portland, Oregon
}

\author{
by \\ Amber Wagoner \\ An undergraduate honors thesis submitted in partial fulfillment of the \\ requirements for the degree of \\ Bachelors in Arts \\ in \\ University Honors \\ and \\ Community Development
}

Thesis Adviser

Meg Merrick, Ph.D.

Portland State University

2016 



\section{ABSTRACT}

This thesis explores the relation between successful revitalization efforts and community engagement initiatives. The cities of Tulsa, Oklahoma, and Portland, Oregon are compared on their most recent planning documents related to their downtown and/or central city. In 2010, The City of Tulsa adopted the Tulsa Comprehensive Plan, as well as the Downtown Area Master Plan (DAMP). These documents began a new era of revitalization after decades of disinterest and neglect for Tulsa's downtown area. Portland's revitalization efforts date back to the 1972 Downtown Plan. The plan launched participatory planning policies and inspired enthusiasm for a vibrant central city that continues to this day. The most recent Central City Plan (2016) echoes many of the earlier plan's values and visions for Portland.

Contextualization of Tulsa and Portland suggest that although they are at different points on their revitalization timeline, their commonalities as cities far outweigh their differences. Comparative analysis between the cities' shows that Portland's policies to assure citizen involvement throughout the planning process have led to stronger and more transparent plans which have withstood the test of time better than comparable documents in Tulsa. Increased community ownership of the planning process in Tulsa is suggested in order to guarantee these plans achieve their goals and stay relevant over time.

RESEARCH QUESTION: How has the City of Tulsa, Oklahoma engaged its citizens in the downtown revitalization plan and process, and what can the city learn from the past 40 years of participatory planning practices in Portland, Oregon? 


\title{
TABLE OF CONTENTS
}

\author{
INTRODUCTION \\ LITERATURE REVIEW 3 \\ Downtown Revitalization 3 \\ Community Engagement 6 \\ METHODOLOGY 10 \\ HISTORICAL CONTEXT: TULSA AND PORTLAND 14 \\ CURRENT DOWNTOWN ENVIRONMENT 32
}

TULSA PLANNING: 1980-2015 49

PORTLAND PLANNING: 1970-2015 57

COMPARATIVE ANALYSIS $\quad 71$

Suggestions from Portland to Tulsa $\quad 74$

$\begin{array}{ll}\text { CONCLUSION } & 76\end{array}$

$\begin{array}{ll}\text { WORKS CITED } & 77\end{array}$

APPENDIX A: PORTLAND PLANNING TIMELINE i

APPENDIX B: PHOTO TOUR OF DOWNTOWN TULSA iii

APPENDIX C: HISTORIC MAPS OF TULSA XXiii 


\section{IMAGES AND TABLES}

Table or Image Title

Page

Table 1: Arnstein's Ladder of Citizen Participation (1969).

Image 1: Connor's New Ladder of Citizen Participation (1988).

Image 2: Tulsa's humble beginnings before the oil booms of the 1900s.

Image 3: Official Map of the city of Portland in 1866.

Table 2: Comparison of City and Metropolitan Area population in OR and OK.

Image 4: Greenwood Avenue before its destruction in 1921.

Image 5: Greenwood after the Riots.

Image 6: Race Riot photo: "Driving the Negro out of Tulsa"

Image 7: Vanport Bible School.

Images 8 \& 9: City of Vanport before and after flooding.

Image 10: Downtown Tulsa and Districts.

Table 3: Comparison of Downtown Tulsa and Tulsa City by Race4

Table 4: Population by Age and Institutionalized for Tulsa City and Downtown.

Image 11: Portland's Central City in 2012 Plan.

Image 12: Tulsans gather at Guthrie Green for one of their summer concerts

Image 13: Portlanders enjoying a summer evening during First Thursday

Image 14: FAST Forward participants.

Image 15: Portland's multi-modal Transit Mall in 2014.

Image 16: Street CReD Polish the Pearl

Table 5: Downtown Tulsa Residential Housing in 2015

Image 17: Central City Plan's Timeline for Drafts.

Image 18: Tulsa Downtown Area Master Plan Area.

Image 19: Harbor Drive looking South toward Hawthorne Bridge, June 1971.

Image 20: Tom McCall Waterfront, facing North from Hawthorne Bridge, April 2012.

Image 21: Study area of Portland's 1972 Downtown Plan.

Image 22: Portland's Central City in 1988.

Image 23: Measurements of Success: 2012 Portland Plan.

65

Table 6: 2016 Walkability Scores for Tulsa and Portland. 


\section{INTRODUCTION}

"Dull, inert cities, it is true, do contain the seeds of their own destruction and little else. But lively, diverse, intense cities contain the seeds of their own regeneration, with enough energy to carry over for problems and needs outside themselves."

Jane Jacobs, The Death and Life of Great American Cities

Downtowns are experiencing a comeback. Many U.S. cities are beginning to realize that healthy, thriving downtowns are at the heart of sustainable, vibrant cities. Cities such as Tulsa, Oklahoma are looking to progressive cities like Portland, Oregon for strategies, plans, and programs that can aid in the revitalization process.

For the past forty years, Portland has been a leading city in its efforts to reinvigorate its central city with participatory planning processes. This process has relied on research, evaluation, and public opinion to learn and grow from past planning mistakes and successes. Portland prides itself on inclusionary participation efforts and transparency in planning procedures.

If Tulsa looks to Portland for guidance, it will be necessary for planners and citizens to understand what strategies were effective, how they impacted affected communities, who was involved in the planning, and why Portland is redeveloping that area. This thesis aims to compare the two cities of Tulsa and Portland, their efforts on downtown revitalization, community engagement, and the symbiosis of these two factors within local government.

Since 2010, Portland has been planning Central City 2035. In 2012, the Central City Concept Plan was released in order to determine the final plan with citizens. Central City 2035 will be officially adopted in 2017 and will affect decisions made in the next twenty years to the region's center. Upon adoption, Central City 2035 will be amended into Portland's Comprehensive Plan, an all-inclusive, long-range plan which helps guide future development and growth throughout the city.

In 2010, Tulsa's Comprehensive Plan and Tulsa Downtown Area Master Plan were adopted by City Council. Although Tulsa's current planning efforts are fairly recent in comparison to Portland, this can serve to benefit the city. Tulsa will be able to access research of effective policies and strategies supported by data collected over the past forty years. 
Three questions will be addressed in this paper:

1. How has Tulsa invited citizens to be actively involved in both long term policy making and short-term project based planning processes?

2. What historical projects and efforts were most influential in creating Portland's current central city?

3. What elements from Portland's policies and guidelines for citizen engagement can Tulsa learn from or adopt?

The literature review will highlight key downtown revitalization practices and strategies to increase community engagement. Historical contextualization of the two cities and previous revitalization attempts are summarized before current downtown and central city environments are described. Analysis will occur from the most recent planning documents, Tulsa Downtown Area Master Plan (2010) and Central City 2035 Concept Plan (2012) and will be supported by historical planning documents. A historical timeline of key projects, policies, and events in Portland will be provided to demonstrate the necessity of long-term planning and consistent citizen engagement.

This topic is of interest based upon my first-hand knowledge of both cities. In 2009, I moved to Portland, OR from my hometown of Tulsa, OK. From the moment I stepped off the MAX into Pioneer Courthouse Square I could tell there was something special about Portland and had to find a way to better understand the city. Portland's central city quickly became my favorite place to be: it was an area bursting with a variety of uses, multiple neighborhoods and districts, and constant activities in which to engage with others and with the city itself.

When I return home, I often view downtown Tulsa under a Portland lens. Vacant concrete lots and quaint abandoned buildings beg for revitalization. Tulsans have always been passionate about their city, and in recent years I have noticed a wide array of changes within the downtown area. This thesis will address these changes in a broader scope, highlight successes, and showcase opportunities for the city to involve Tulsans in the revitalization process. 


\section{LITERATURE REVIEW}

\section{DOWNTOWN REVITALIZATION}

There are a myriad of strategies in which a city (or town) might revitalize their downtown; many of these strategies have been tested in multiple cities with varying degrees of success. While each city will have unique circumstances surrounding downtown development, there are certain approaches which have been studied extensively.

Many of the more common practices were assessed by Kent Robertson in the article Downtown Redevelopment Strategies in the United States (1995). Robertson discusses seven major downtown redevelopment strategies at that time: pedestrianization; indoor shopping centers; historic preservation; waterfront development; office development; special activity generators; and transportation enhancement. Robertson is presenting these seven strategies as widely used and therefore more reliable forms of revitalization. At the time, many people were still debating the success of these redevelopment strategies; Robertson's article serves to validate their success. A few of these strategies are discussed in more detail later in the review.

Robertson showcases the factors present during the height of downtown development during the 1920s. He attributes this development to the economic growth experienced during the decade. The Great Depression (1929-1939), along with economic resources and industries being diverted to World War II during the early 1940s, contributed to the decline of downtowns. Robertson also cites the shift from downtowns to suburban areas and rising automobile use as further contributing factors.

Robertson identifies four generalizations of downtown revitalization; although this article was written over 20 years ago, these generalizations still ring true for many cities.

1. Many downtowns have chosen a "corporate center" approach and have lost the authenticity present with local small businesses. With a one-dimensional town there is less diversity in space use and users.

2. Downtowns are becoming less dense, primarily due to the construction of parking lots, roads, and ramps for automobile use. "A lower density downtown, used less frequently by pedestrians and transit riders, has less of the street activity that is often a gauge of downtown vitality" (Robertson 1995).

3. Tourism should be integrated into the downtown plan and spillover effects to other areas surrounding downtown should be regulated. Although spillover effects may benefit surrounding neighborhoods, it can also lead to gentrification and eventual 


\section{DOWNTOWN REVITALIZED, COMMUNITY ORGANIZED}

displacement of residents. Gentrification is the process in which previously neglected areas are reinvigorated by a wealthier class, thus raising property values and pushing out poorer residents. This topic will be discussed in more detail later in the review.

4. Downtowns tend to have more distinct identities that the surrounding metropolitan area and are often considered the center for business, entertainment, and culture in a city.

Based upon the four generalizations and seven strategies, Robertson offers several recommendations for downtown development in the 21 st century. These include: maintain high density levels; create genuine civic public places connected to community identity; preserve historic places; develop and enforce design controls for a more fluid downtown landscape; plan for a multi-functional downtown; and stress the importance of street-level activity for pedestrians (Robertson 1995).

In order to redevelop downtown, local government must adopt a plan which will guide the process. Charles Leinberger discusses this in Turning Around Downtown: Twelve Steps to Revitalization (2005). Leinberger outlines an effective twelve step revitalization plan that has an end goal of creating a downtown area that fosters walkable urbanism; many of these steps support Robertson's suggestions and strategies offered ten years prior. Leinberger stresses that the steps are to be sequential in order to yield the best results; he also states that as downtowns continue to evolve, these steps must also evolve.

1. Capture the vision. Leinberger stresses that any plan should have clear intention behind it. A history of previous failed attempts, as well as community emotions associated with these failures, need to be addressed before creating a new plan for downtown. Once there is motivation present, then the visioning process can begin. This process is often led by prominent stakeholders, such as property and business owners, community leaders, and politicians related to the downtown area.

2. Develop a strategic plan. Leinberger identifies ten categories to consider when creating a strategic plan for downtown: characteristics; housing; retail; culture; public infrastructure; employment; community involvement; non-profit involvement; marketing; and social values. A balance in these categories, along with a balance in stakeholders invited into the planning process, will strengthen the final strategic plan.

3. Forge a healthy private/public partnership. Most often, private entities are leading the development and revitalization efforts with support from public agencies. Leinberger 


\section{DOWNTOWN REVITALIZED, COMMUNITY ORGANIZED}

suggests that the role of the public sector is to avoid an overly political process which may lead to the plan not being able to withstand government turnover. City leaders should be committed to the process without micromanaging the efforts of private sector development.

4. Make the right thing easy. The process should be easy for private developers, nonprofit organizations, and community members to understand. Leinberger's primary suggestions for this step are to completely rewrite the zoning code for the downtown area in order to delineate boundaries, set expectations for building character, and reinforce walkable urbanism. Mixed-use development and reconfiguring of right-ofways on streets are critical factors in promoting walkable urbanism.

5. Establish Business Improvement Districts (BIDs) and other non-profits. BIDs are funded by property owners who voluntarily increase their property taxes to fund improvements within their districts. Leinberger argues that BIDs and other non-profits help to: increase the perceived or actual safety of downtown; upkeep the cleanliness and imaging or marketing of downtown, and support events and festivals that draw citizens and visitors to the area.

6. Create a catalytic development company. Leinberger suggests that city leaders should support a development company that produces initial projects that showcase market risk and demand so that other companies have a more confident understanding of the conditions of developing downtown property.

7. Create an urban entertainment district. Elements of an entertainment district include: arenas, performing arts centers; movie theaters; restaurants and nightclubs; specialty retail; festivals and events; and emphasize arts and culture representative of the city.

8. Develop a rental housing market. Strategic plans should include support for renters, which tend to be younger and have lower incomes than homeowners. Property developers will need incentives to build housing for renters and city officials should have a plan in place to support these developers.

9. Pioneer an affordability strategy. Generally, this strategy will focus on housing but it is also relevant for business owners. As downtown revitalizes, property values will increase and it will become more difficult to have a diverse economic base in downtown. An affordability strategy is most often mandated by city government. Leinberger suggests that careful consideration of future development concerns and current conditions can improve the strategy. 


\section{DOWNTOWN REVITALIZED, COMMUNITY ORGANIZED}

10. Focus on for-sale housing. Leinberger states that young professionals, both single and partners, and "Baby Boomer" empty nesters are a natural market for housing for sale. He suggests that for-sale housing targeted at the middle and upper-class is crucial in order to improve the tax base of downtown.

11. Develop a local-serving retail strategy. Leinberger presents two reasons why downtowns are often underserved by retail businesses: retail structure has changed from corner stores and "mom and pop" shops to larger outlets serving a wider radius of people; and local retail is considered a following effect of real estate development. He suggests that once there is a need presented by downtown residents for retail services, these businesses will begin to move to the area.

12. Recreate a strong office market. Many downtowns are still considered the central business district and serve as the government hub for their city, however many downtowns struggle to compete with suburban areas for employment. Leinberger suggests this step last and argues it is more necessary to bring residents back into downtown before large employers. As more residents move from suburban areas to the downtown area, more employers will be inclined to follow.

Dagney Faulk reviews downtown revitalization strategies in The Process and Practice of Downtown Revitalization (2006). She recommends that downtown density should be strengthened and amenities enhanced to invigorate the area. This recommendation strengthens Robertson's suggestion for high density downtowns designed for pedestrian use. Faulk also suggests that a central organization in charge of downtown revitalization efforts is key to success. This organization could play a key role in balancing the private/public relationship discussed by Leinberger in the third step of his revitalization plan. Faulk also concludes that the process will be different for each city and that projects need to be tailored to the communities present. 


\section{COMMUNITY ENGAGEMENT \& PUBLIC PARTICIPATION}

Community engagement is an essential component for a participatory planning process. There are a variety of toolkits, lesson plans, and research articles geared at successfully creating inclusive communities and policies. The National Standards for Community Engagement define the process as "developing and sustaining a working relationship between one or more public body and one or more community group, to help them both to understand and act on the needs of the issues that the community experiences" (2005).

An important tool for public participation is Sherry Arnstein's Ladder of Citizen Participation (1969). Arnstein delineates between citizen power, tokenism, and nonparticipation with eight types of participation. Many nonprofits and governments turn to Arnstein's Ladder to ensure they have a balance in ways the community can be involved. Arnstein stresses that in real life there are many more types and strategies that are more difficult to prescribe within these eight rungs.

\begin{tabular}{|c|c|c|}
\hline \multirow{3}{*}{$\begin{array}{l}\text { Citizen Power } \\
\text { True citizen participation that balances power } \\
\text { between decision makers and the larger community }\end{array}$} & 8 & Citizen Control \\
\hline & 7 & Delegated Power \\
\hline & 6 & Partnership \\
\hline \multirow{3}{*}{$\begin{array}{c}\text { Tokenism } \\
\text { Symbolic efforts often aimed at minority groups } \\
\text { which allow them to be seen and heard by decision } \\
\text { makers }\end{array}$} & 5 & Placation \\
\hline & 4 & Consultation \\
\hline & 3 & Informing \\
\hline \multirow{2}{*}{$\begin{array}{l}\text { Nonparticipation } \\
\text { Substitutes for genuine participation that educate } \\
\text { instead of empower }\end{array}$} & 2 & Therapy \\
\hline & 1 & Manipulation \\
\hline
\end{tabular}


In 1988 Desmond Connor published $A$ New Ladder of Citizen Participation, which suggests an alternate way of engaging the public, and emphasizes the difference between rural and urban engagement, as well as the roles of the public and private sector. Connor's ladder creates distinction between the general public and leaders in the community and government. His seven rungs aim to "provide a systematic approach to preventing and resolving public controversy" around planning policies and decisions.

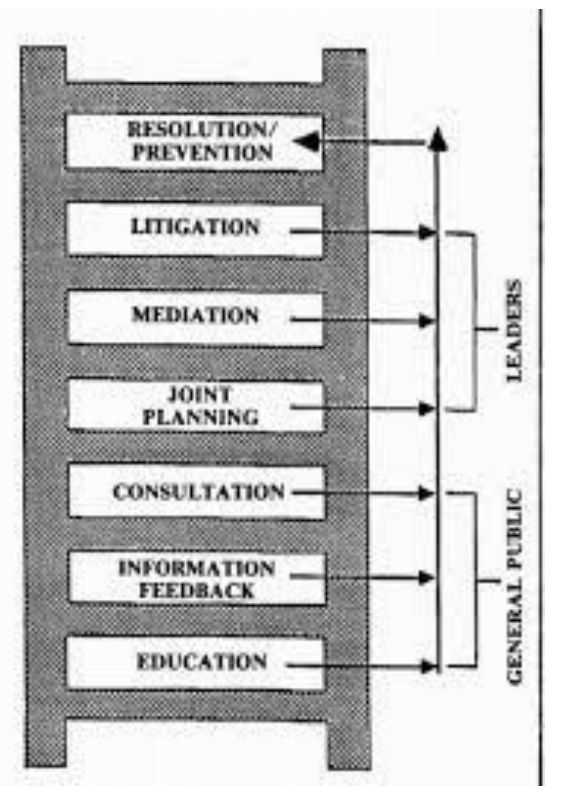

Image 1: Connor's New Ladder of Citizen Participation (1988)

Successful community engagement plans will always come at a price. The financial aspect may deter governments or organizations from long-term community engagement and choose engagement efforts which are quick and cost efficient. The difficulty in not having a longterm engagement plan is that as changes occur, public opinion also changes. Promising Practices for Long Term Community Engagement (Merrick \& Tremoulet 2015) examines the role(s) of Citizen Participation Organizations (CPOs), provides multiple profiles of cities which vary in their approaches, and best practices for long-term community engagement. This report was prepared for Washington County, Oregon, which neighbors Multnomah County, where Portland is located.

'Those seeking the 'perfect model' for Washington County's community participation program will not find it in these pages. There is no silver bullet, no perfect model. There are, however, a series of choices to be made, each with its own benefits and limitations" (Merrick \& Tremoulet 2015).

Portland's history of community organizing and public participation has been explored in detail by Paul Leistner (2013) and Steven Johnson (2002). The two dissertations help to create a clear connection between the history of civic democracy (1970 onwards) and current public participant trends in the city. Leistner argues that true participatory democracy requires three elements within a city's comprehensive plan: increasing the breadth of people and communities 


\section{DOWNTOWN REVITALIZED, COMMUNITY ORGANIZED}

involved in their city's civic life; strengthen community capacity and help citizens organize around local issues; and "significantly improve the willingness and ability of city leaders and staff to work in partnership with community members and organizations" (Leistner 2013). Leistner also introduces the need for a broader definition of community: although many communities are geographically based, communities based on culture and shared interest should also be involved in participatory democracy.

Two sources for community engagement tools and strategies can be found online: Community Tool Box and Community Planning Toolkit. They are geared towards citizens and community organizers and can serve as a guide through the engagement process.

Community Tool Box is an online workbook for anyone interested in improving their community. This is an important tool, as it is aimed at anyone who has the motivation yet lacks the necessary knowledge in which to change their communities. The online workbook covers essential knowledge for community assessments, public participation, plan implementation, program analysis, as well as many more topics.

Community Planning Toolkit is another resource that puts planning power back into the hands of citizens. The Community Engagement component or chapter of their program has the potential to serve as an outline of strategies or tools communities or governments have in which to inclusively engage the larger population of their city. This chapter also lists the $10 \mathrm{National}$ Standards for Community Engagement, which was published by the Scottish Community Development Center in 2005. 


\section{METHODOLOGY}

\section{Portland Planning Timeline}

This section will serve as an illustrative tool to better understand the past 45 years of development efforts in Portland, OR in comparison to the 5 years in Tulsa, OK. Redevelopment and revitalization efforts will be concentrated to the Central City/Downtown area in Portland, OR, beginning in 1970. Before 2010, the last time the Tulsa Comprehensive Plan was updated was in 1972. Research and assessment have been performed on the majority of past plans and can speak to the success of a certain type of effort.

This timeline will serve two purposes. The first will be to better understand Portland's revitalization and public participation efforts. The second is to suggest future opportunities or modes of engagement for Tulsa.

\section{Qualitative content analysis of key planning documents}

This section aims to answer the question; "How, when, and why did we get here?" It represents current revitalization and community engagement efforts in both cities, as well as what past efforts led to the current situation in each respective city. Although there is a wealth of planning documents that could be analyzed, it is necessary to scale planning documents to those which focus on the central city or downtown area.

The four planning documents listed below will be utilized in this section:

1. Portland Central City Concept Plan (2012)

2. Tulsa Downtown Area Master Plan (2010)

3. Tulsa Comprehensive Plan (2010)

4. Portland Plan (2012)

The analysis occurs primarily from Portland Central City Concept Plan and Tulsa Downtown Area Master Plan. Portland and Tulsa's comprehensive plans will serve to highlight citywide goals, themes, and policies which have influenced their respective central city and downtown plans. How these overarching themes actually manifest will be analyzed from the perspective of the downtown area.

Portland's earlier planning documents will serve as a tool to assess how Portland's implementation of Best Practices has fared in the past 45 years. Portland's 1972 Downtown 
Plan and the 1988 Central City Plan will help to create a better understanding of this time intensive process. The transition from downtown to central city will also be explored.

By showing Portland's long history with downtown revitalization and public participation, as well as examples of where their plan strengthened or weakened the community, an argument can be presented to Tulsa as to how slowly and deliberately they may need to move for effective and inclusive change. It may also serve to show that although foresight is ideal when embarking on revitalization projects, it is not possible to know the effect of these changes immediately, and thus follow-up research must be done to assess the efforts being made.

It should be noted that the amount of data and research available is not comparable for Tulsa, OK and Portland, OR. The areas in which data was sparse were early revitalization efforts: Urban Renewal, Model Cities, and early planning documents for both Tulsa and the downtown area were difficult, if not impossible, to find. Although the information exists for Tulsa's early revitalization efforts, the majority of these documents are not available online. Tulsa City-County Library is in the process of converting its archive system to a digital archive system; I was able to request certain documents be digitized as soon as possible with the help of family members who went in person to review the documents.

The following documents were obtained through the Tulsa City-County Library Archives Department:

District 1 Plan (1980) by Tulsa Metropolitan Area Planning Commission Tulsa Model Cities (1971) by Tonne England

Business Relocation and Downtown Tulsa Renewal (n.d) by Judy Shriver Tulsa Urban renewal (1967) by Jo Ann Boatman

A select number of maps from these three documents are presented in Appendix C.

Multiple strategies and practices have been employed by city planners and leaders to revitalize their city's downtown. Some of the most researched and widely used practices are walkability, historic preservation, and the creation of economic incentives for developers. These three practices are also examined by Robertson (1995) and Leinberger (2005) and were chosen for analysis due to their relevance for planning in Tulsa, OK and Portland, OR. 


\section{Walkability}

It is widely agreed upon that when central cities are designed for people instead of automobiles they have the potential to be more socially active, economically vibrant, and environmentally friendly (Robertson 2007, Brambilla and Longo 1977). There are a variety of factors which can encourage urban walkability; efficient rail transit and neighborhood proximity to the downtown or central city are common among some of America's most walkable cities (Leinberger 2005).

City planners can implement multiple strategies to increase walkability. Some cities, such as Curitiba, Brazil, have completely or partially removed the automobile from sections of their city centers. These streets can be pedestrian oriented, mixed-use (which allows for limited auto use), or multi-transit: public transit, bicyclists, pedestrians, and automobiles all sharing the road (Robertson 1995).

There are multiple online tools and apps which are able to measure walkability of neighborhoods and cities. Walk Score uses Google Maps in order to record the distance from residential addresses to nearby destinations. These destinations are organized into 13 categories of basic goods and services, including grocery stores, restaurants, schools, and coffee shops. More points are awarded for the least amount of distance between residential addresses and destinations. Walk Score can be considered limited by the amount and type of categories, as well as in its measurement of straight-line distance which does not necessarily take traffic and obstacles into account (Cortright 2009, Brewster 2009).

\section{Historic Preservation}

Vibrant city centers often embody multiple decades and types of architectural style. While some buildings are renovated and added to the National Register of Historic Places, others lay abandoned in varying states of disrepair. Historic preservation allows for the character of a district to stay intact while also diversifying uses of the area (Robertson 1995). The U.S. National Park Service's National Register of Historic Places coordinates public and private efforts to preserve historic buildings, landmarks, and neighborhoods and has been in place since 1966.

More often than not, it is more economically feasible to rehabilitate a space than begin new construction (Rypkema 1991, Mason 2005). Mason (2005) states that developers need to consider the long term effects of rehabilitation; when building are located in historic areas, property values tend to increase over time and economic benefits can be seen throughout the 
community (Mason 2005). Rypkema (1991) emphasizes that preservation must be taken on a case by case basis, depending on building integrity and cost for rehabilitation.

\section{Economic Incentives}

A significant component of downtown revitalization is supporting economic development. Robertson (1995) and Leinberger (2005) mention the importance of creating a thriving economy in downtowns, as well as the importance of attracting developers and investors to the area.

Tax Increment Financing (TIF) is one of the many tools governments can use to capture revenue and invest it back into the city. TIF allows for the designation of an area in need of revitalization or improvement. Property tax revenues, often from a municipality's general fund, are reallocated to the TIF area. TIF became a popular economic development option when federal funding decreased during the 1970s and 80s (Weber 2013).

Dye and Merriam (2000) analyze the effects of TIF in the article The Effects of Tax Increment Financing on Economic Development by examining the city of Chicago, IL before and after TIF adoption. They found that a positive effect was felt within the TIF districts; however this effect was outweighed by the negative impacts on property values outside of the TIF area. 
DOWNTOWN REVITALIZED, COMMUNITY ORGANIZED

\section{HISTORICAL CONTEXT: TULSA AND PORTLAND}

This chapter aims to create context for both cities. It provides a snapshot of the origins of the cities within the states, periods of growth, racial tensions, downtown degradation, and revitalization efforts of the late 20th century.

\section{States of destination}

Oklahoma has its roots in one of the largest injustices ever enacted by the federal government: The Trail of Tears, which began with the 1830 Indian Removal Act. Under President Andrew Jackson's orders, the federal government began forcefully removing the Five Civilized Tribes from their ancestral lands located throughout the United States into the newly established Indian Territory. The Five Civilized Tribes (Cherokee, Creek, Choctaw, Chickasaw, and Seminole) had to endure terrible conditions for multiple weeks; harsh winter weather, lack of adequate shelter and a diminishment of federally provided supplies led to many people dying on the Trail.

The present day Creek Nation Council Oak Park, located a few blocks south of downtown, marks the location where the Creek Nation would gather for government and religious reasons. Tribes originating from the South often included businessmen and plantation operators; they brought any slaves they owned with them on their migration. It is likely that the Creek nation, which established itself in present day downtown Tulsa, brought African slaves to the area (LaFortune 1974).

Indian Territory would remain autonomous until 1890, when the Oklahoma Organic Act would allow for a federal judicial system and eventual statehood (Everett n.d). This act followed the Land Run of 1889, which allowed African Americans, as well as white men and women, to stake their claim on up to 160 acres of prairie land. These lands were not available to Native Americans already living in the territory that aligning with the Confederacy during the Civil War. Creek and Cherokee Nation both sided with the Union and were able to keep their strong presence in Tulsa intact (LaFortune 1974).

Tribes currently tend to be located on reservations further from major cities, leaving these citizens with decreased access to resources and economic opportunities. Tulsa's Native American population was $5.3 \%$ of the total population; in comparison, Native Americans make up $8.6 \%$ of Oklahoma's population (U.S. Census 2010). 
In 1772, Robert Gray became the first English-speaking explorer to reach Oregon when his team came upon the Columbia River. Over the next three decades more explorations followed, including the Lewis and Clark expeditions of the Columbia in 1805-06. The site of Portland would not be explored until much later, due to its lack of importance for the local Chinook, Clackamas, and Multnomah tribes. Explorers marveled at the lush forests and fertile lands which led to a moderately easy life for Native Americans. Chinook tribes became trading partners for both American and British fur companies; this partnership would bring economic gains however would lead to the eventual demise of the Native American tribes inhabiting the area of Portland (Abbott 1993).

The "Cold Sick" of 1829 practically obliterated white settlements in Northwest Oregon. New settlements would continue to ignore the Portland area, choosing instead to settle more North along the Columbia River. Oregon would continue to be settled by multiple groups from Britain, America, and French Canadians.

In 1843, nearly 1,000 people migrated to the area from Missouri. Over the next few years, thousands of Americans would brave the Oregon Trail in promise of a better life and economic opportunities. Control of Oregon Country (Idaho, Oregon, Washington, and British Columbia) would stay an international dispute until the 1846 Oregon Treaty between the United States and Britain along the $49^{\text {th }}$ parallel (Abbott 1993).

Although this Treaty would solidify white migrants' ownership of the area, it would also lead to racist exclusion laws passed in the 1840 s aimed at Chinese, Japanese, Native Americans, and African Americans. The 1844 exclusion law stated that any person who brought slaves with them to Oregon must remove the slaves from the state. In 1857, the Oregon State Constitution Convention passed a resolution that no free Blacks would be allowed to reside in the state.

Article XVIII, Sec. 4 of Oregon State's Constitution states " if a majority of all the votes given for, and against free negroes, shall be given against free negroes, then the following section shall be added to the Bill of Rights, and shall be part of this Constitution: no free negro, or mulatto, not residing in this State at the time of the adoption of this Constitution [i.e., 1857], shall come, reside, or be within this State, or hold any real estate, or make any contracts, or maintain any suit therein; and the Legislative Assembly shall provide by penal laws, for the removal, by public officers, of all such negroes, and mulattoes, and for their effectual exclusion from the State, and for the punishment of persons who shall bring them into the State, or employ, or harbor them." 
The Fourteenth Amendment to the U.S. Constitution, passed in 1866, would render these laws moot, although they were not repealed by voters until 1926. These laws have greatly contributed to Oregon's current demographics: 84 percent of the state is White, with a Black population of 69,206 people - roughly 2 percent of the state population. Over half of Oregon's Black residents reside in the city of Portland (U.S Census 2010).

\section{Foundations of the city}

Tulsa's origins as a city can be traced to the early 1830 s when displaced Native American tribes chose to settle near the Arkansas River. The Lower Creek tribe initially settled in present-day Tulsa after negotiating a land treaty with nearby Cherokee tribes. In 1882, the St. Louis and San Francisco Railroad arrived in Tulsa, establishing the city and prompting business development. The city was incorporated January 18,1898 . When Oklahoma became a state in 1907, Tulsa had a population of 7,298 - this number would more than double by the 1910 U.S. Census (Gregory n.d).

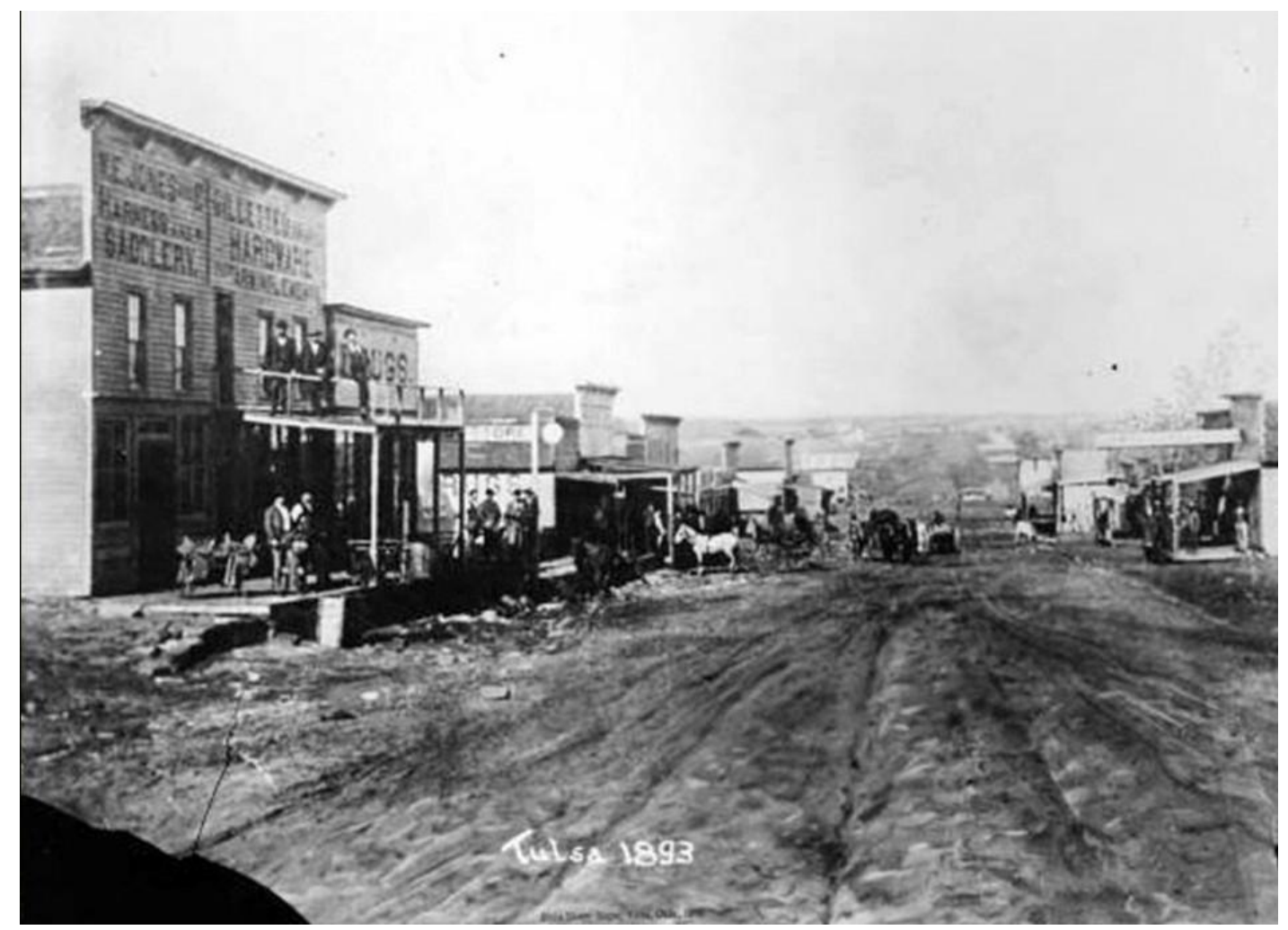

Image 2: Tulsa's humble beginnings before the oil booms of the 1900s. Source: Tulsa Historical Society.

The 1900s would bring the discovery of oil throughout Tulsa and surrounding areas; the city was coined "the Oil Capital of the World". The discovery of oil allowed for rapid infrastructure, industry, and higher education development; this growth continued throughout the 
early 20th century. Aviation and transportation industries contributed greatly to population increases in subsequent decades. Tulsa was quickly becoming a beacon "in the Midwest" of prosperity and new beginnings. The entrepreneurial spirit of the oil boom would shape the attitudes of Tulsans for generations to come (Gregory, n.d).

Portland began to develop in 1843, after many years as a pit stop along the trading route between Fort Vancouver and Oregon City. The name of the city was decided by an infamous coin toss between founding fathers Asa Lovejoy and Francis Pettygrove. Lovejoy, who hailed from Massachusetts and wanted the site to be called "Boston", lost the toss to Pettygrove, who was originally from Maine and chose "Portland" as the name for their new town. In 1847 the town had 100 settlers; by the 1860 Census, the town's population had grown to 2,874 people and would continue to grow exponentially (Abbott 1997).

The California Gold Rush spurred the trade of lumber and wheat between San Francisco and Portland. The city was incorporated on February 8, 1851. In 1883 the Northern Pacific Railroad was completed, allowing Portland's lumber, agriculture, and ranching industries to flourish across the Pacific Northwest (Abbott 1997).

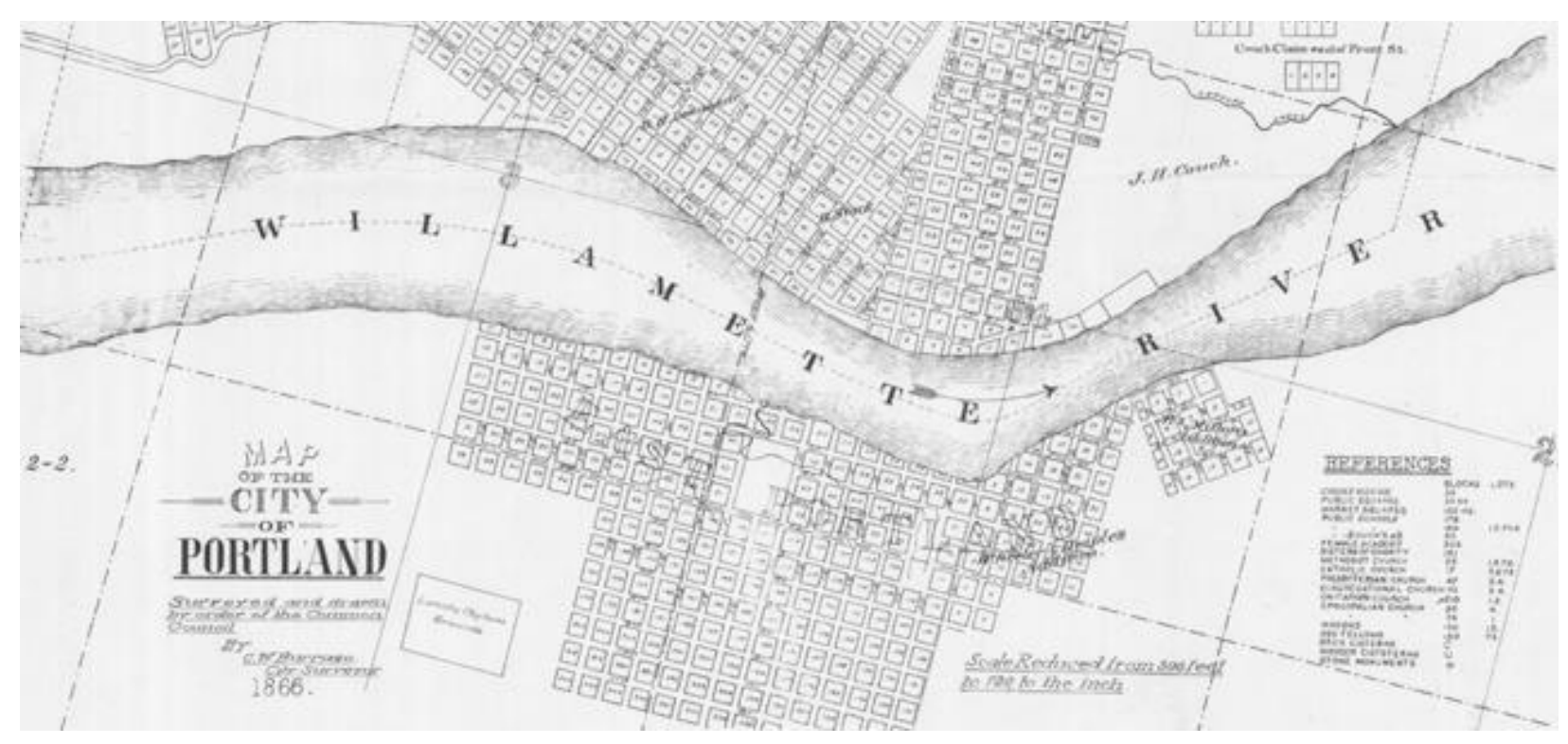

Image 3: Official Map of the city of Portland in 1866. Source: City of Portland.

This economic boom would attract immigrants, beginning with a large Chinese community, second only to San Francisco, in the 1880s. In the following decades, immigrants from Japan, Scandinavia, Eastern Europe, and the Mediterranean would begin to call Portland home. By 1910, the largest immigrant populations in Portland would also include people from 
the British Isles, Germany, Sweden, Canada, and China, followed by Russia and Italy in later years.

The diversity in ethnicities created a collusion and general tolerance of cultures that can still be observed in Portland today. The Lewis and Clark Exposition of 1905 would solidify Portland's reputation as a progressive, economically vibrant, and innovative town. This can-do attitude is very much alive in the modern Portland (Abbott 1997).

\section{City and state}

Tulsa and Portland are both in states which are comprised of mostly rural towns and agricultural areas. Both cities are part of a greater metropolitan area interconnected to surrounding smaller cities and towns. Tulsa relies on highways for this connection; Portland utilizes highways and multi-modal public transit via buses and light rails.

Both cities serve as the more progressive voice in conservative states. Oklahoma is often associated with the Midwestern states that comprise "The Bible Belt" and is known for strong religious values which emphasize family and community. These values are also important in Oregon, however the state is often overshadowed by the large population and big personality of Portland.

\begin{tabular}{lrrlrr}
\hline \multicolumn{1}{c}{ Oregon } & Population & $\%$ of state & \multicolumn{1}{c}{ Oklahoma } & Population & \% of state \\
\hline Portland & 583,776 & 15.2 & Tulsa & 391,906 & 10.4 \\
Portland Metro Area* & $2,226,009$ & 58.1 & Tulsa Metro Area & 937,478 & 25.0 \\
Oregon & $3,831,074$ & -- & Oklahoma & $3,751,351$ & --
\end{tabular}

Table 2: Comparison of City and Metropolitan Area population in Oregon and Oklahoma as a percent of total state population. *Portland-Vancouver-Hillsboro OR-WA MSA

Source: 2010 US Census

\section{Natural environment}

Tulsa and Portland both originate at rivers: Portland is defined by the Willamette and Columbia, while Tulsa lies along the Arkansas. This similarity is essential, as it helped both towns establish themselves as important shipping destinations early in their history. Portland's rivers continue to affect the economy and culture of the city. Tulsa's economic dependence on 
the Arkansas River is minimal, as transport of goods is predominantly by train or freight, however the river is still utilized by Tulsans for leisure.

Portland is known for its proximity to natural areas, such as Mt. Hood National Forest and Forest Park. The city is blanketed in green space with residents who pride themselves on living active outdoor lives. A native Portlander might be shocked when experiencing the flat prairie lands that surround Tulsa, yet Tulsans take just as much pride in enjoying the outdoors. Turkey Mountain Urban Wilderness Area is a common destination for Tulsans, as well as Oxley Nature Center. While the landscapes may differ, the residents' enthusiasm for parks and recreation are similar.

\section{Racial Tensions}

Tulsa and Portland have been shaped by racial tensions since their beginning. The ways in which these play out in the communities are very different. Tulsa, built on the injustices of the 1830 Indian Removal Act, has a dark history with race based violence dating back to the early 1900s. Wounds from the Tulsa Race Riot of 1921 are still felt by communities and citizens and these injustices allow for disparities amongst White and Black Tulsans. To this day Tulsa is seen as a segregated city which refuses to accept its brutal past. The 2014 documentary Hate Crimes in the Heartland addresses the current race issues Tulsa faces.

Portland was able to stay predominately White due to Oregon's Exclusion Law of 1844, which effectively banned both freed and enslaved African Americans from residing in the new state. The ban was repealed in 1927; however African Americans did not begin moving to Portland until the rise in labor demands following U.S. entry into World War II. After the Vanport flood in 1948, minimal effort was made to truly integrate displaced residents into the city.

Currently, one of the most pressing issues in Portland is gentrification, the process in which previously neglected and disinvested neighborhoods are reinvigorated, often economically and then socially. Gentrification often leads to rising property values, influx of new residents, and displacement of the original residents and community (Gibson 2007). The gentrification of neighborhoods in North/Northeast Portland has directly contributed to mass displacement of African American/Black residents. Karen Gibson's article Bleeding Albina: A History of Community Disinvestment, 1940-2000 (2007) gathers historical documents, census data, and oral stories to analyze segregation and displacement of Black residents in North and Northeast Portland. 


\section{Tulsa Race Riot of 1921}

The Tulsa Race Riot of 1921 is arguably one of the worst incidents of racial violence in American history and the most disturbing event of Tulsa's history. In 1921, Tulsa was experiencing the influx of wealth, commerce, and population growth attributed to the oil boom. Tulsa was a segregated city, however African American residents were allowed to work, not live, in Downtown Tulsa. Most of Tulsa's 10,000 African American residents lived in the Greenwood District, located north of downtown (see Appendix C for map of Greenwood and Tulsa Race Riot site). The area was more commonly referred to as "Black Wall Street" and was known in the Southwest for the amount of successful black-owned businesses and the possibility of a better life for a community rarely accepted in other cities. (Ellsworth 2001).

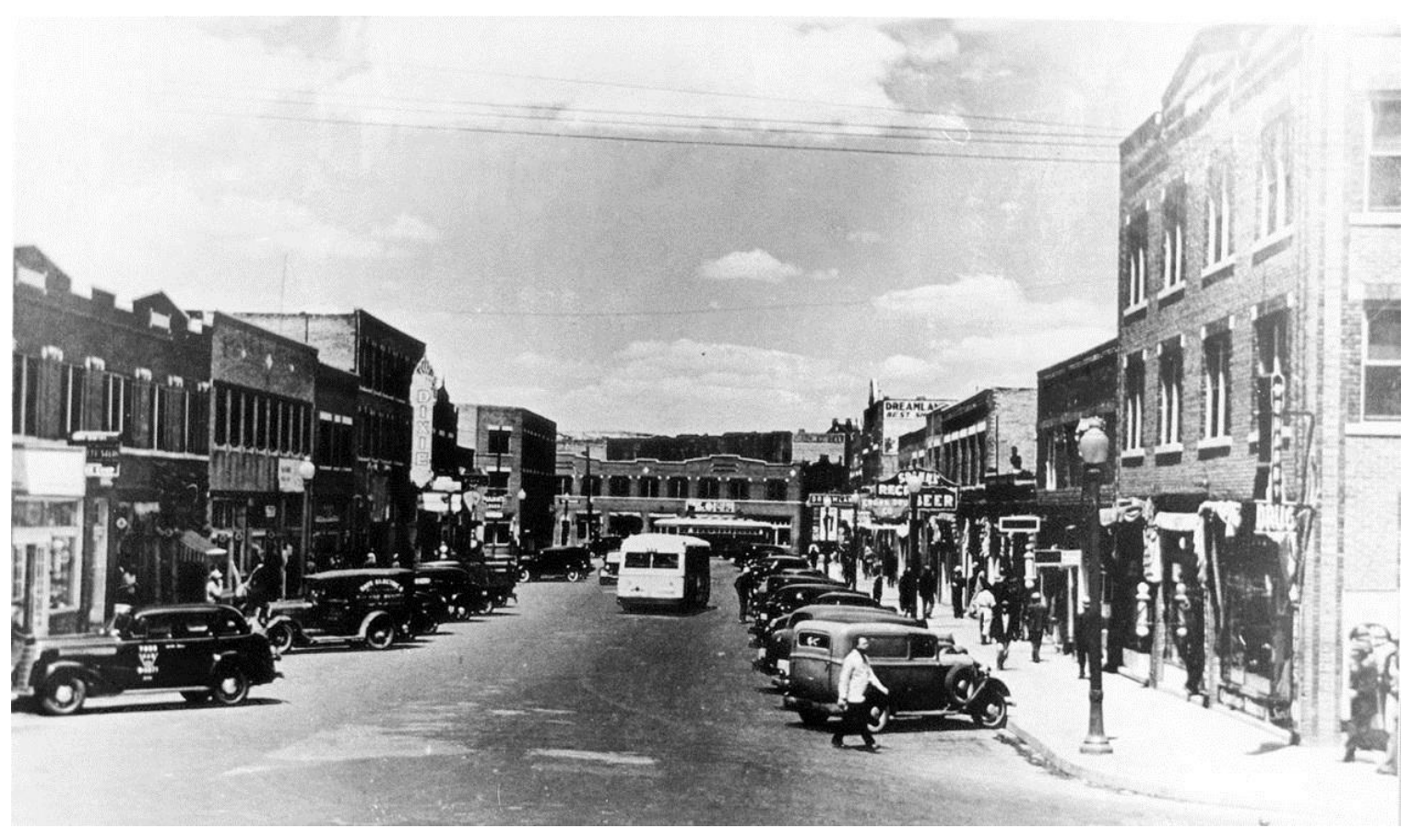

Image 4: Greenwood Avenue before its complete destruction by white Tulsans in 1921. Source: Tulsa Historical Society. 


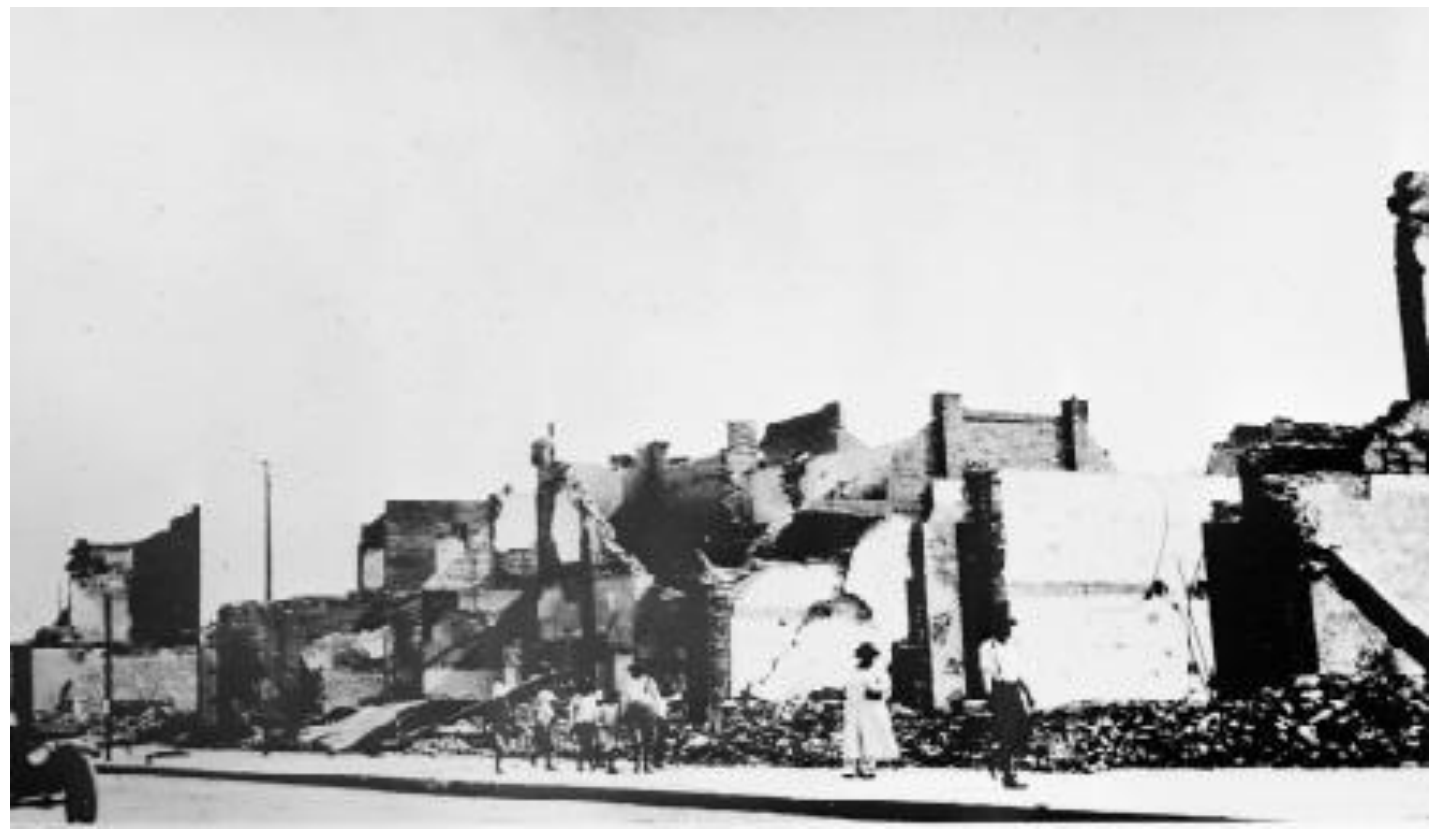

Image 5: Greenwood after the Riots. Source: Oklahoma Historical Society.

Crime and resulting vigilante action were not unheard of in the booming city, so when Sarah Page, a white elevator operator, screamed in an elevator with Dick Rowland, an African American shoe shiner, inside, the underlying tensions erupted. White Tulsans ordered Rowland be lynched, Black Tulsans ordered for a fair trial, and while the city acted on neither request, the riots began and were focused solely on the Greenwood District and the African American population (Ellsworth 2001).

In the following eighteen hours, it is estimated that over 1,000 homes and businesses were destroyed; death rates range from 50 to 3,000 residents (Ellsworth 2001). Residents of the once thriving "Black Wall Street" found themselves homeless and without community. No whites were ever sent to prison for the crimes committed. While parts of Greenwood were rebuilt, the event is still taboo and many of the following generations were not taught about the deeply scarring event. 


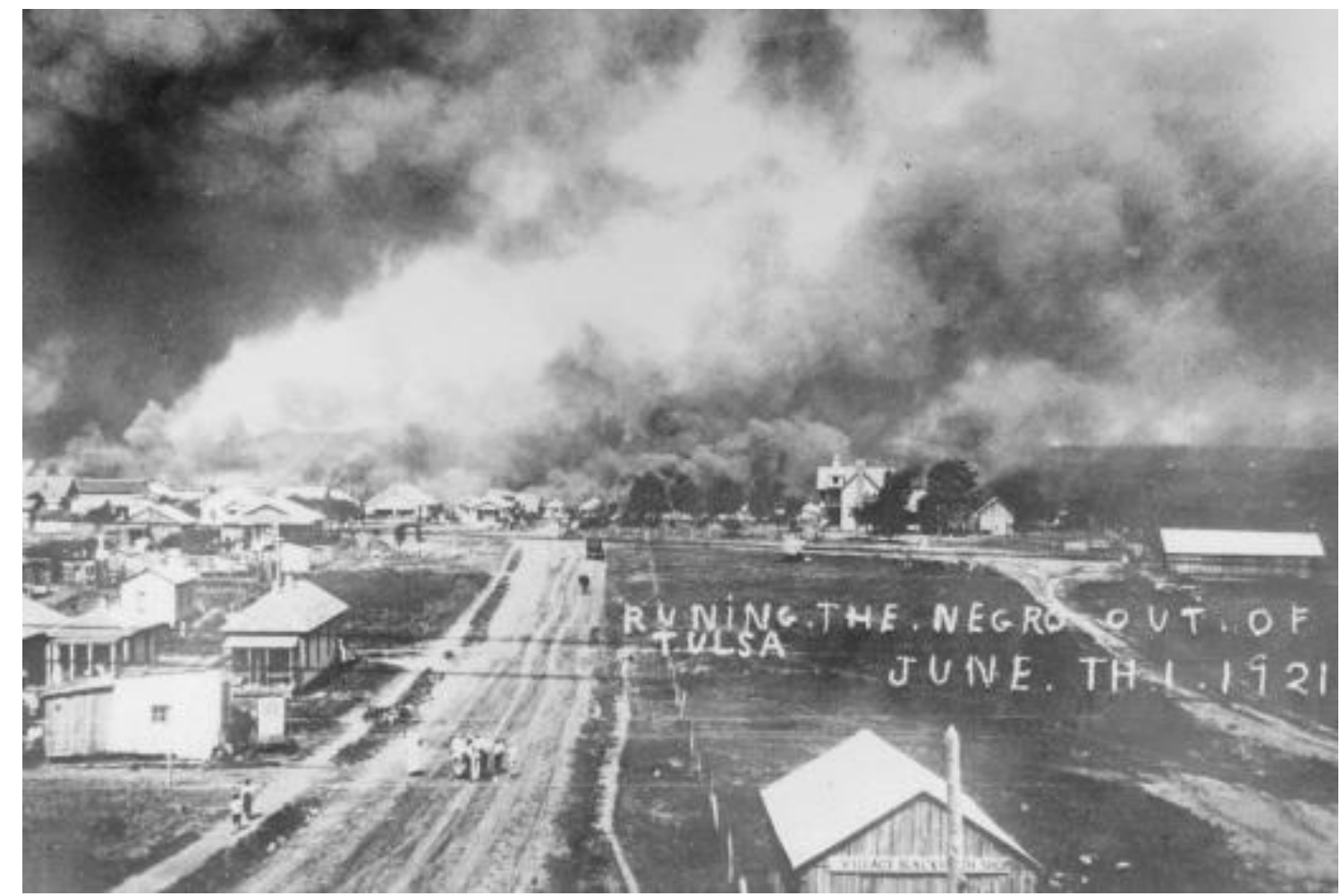

Image 6: The 1921 Race Riots were initially seen as a success by the majority of Tulsans and multiple papers would publish photographs and articles praising the destruction of Greenwood and "Black Wall Street". Source: Greenwood Cultural Center

Downtown Tulsa still serves as the crossing point for the historical segregation of North and South Tulsa. North Tulsa is still primarily an African American community; large expanses of vacant land are begging to be redeveloped into parks, grocery stores, and other community resources that are severely lacking. The abandoned homes and derelict buildings paint a very different picture of disinvestment, exclusion, and inequitable allocation of resources.

As the centennial of the riots approaches, citizens and groups are organizing in order to respectfully remember those affected, while also preparing ways in which to engage Tulsans throughout the city. This effort is spearheaded by the John Hope Franklin Center for Reconciliation and the Greenwood Cultural Center. Both of these organizations have also been instrumental in data collection including photographs, newspaper clippings, and direct testimonies from survivors. The 2008 documentary Before They Die! chronicles the Tulsa Race Riot and gives the opportunity for survivors to tell their stories. 


\section{Portland: Vanport and Gentrification}

In the early 1940s, Portland was experiencing a housing shortage due to the dramatic increase in WWII defense employment. Vanport, a temporary wartime housing development, was built in 1942 to house the workers and their families who flocked to the city for employment. The temporary city was located in North Portland and was spearheaded by Henry J. Kaiser of Kaiser Shipyards. At its peak occupancy in 1944, Vanport's population was 42,000, making it Oregon's second most populated city (Abbott 1983). Vanport had all the amenities of a city including shopping centers, a hospital, and schools. The city was never incorporated into Portland and both local and state governments were largely hands off on Vanport's development.

Vanport was an opportunity for African American families as many were moving to the west coast for wartime manufacturing jobs; it was one of two housing projects in Portland that housed Black residents. African American residents encouraged integration, however the majority of white residents complained about the presence black residents and opposed integrated services (Abbott 1983). Vanport still served a great role in elevating the lives of Black residents, providing education and government jobs before many cities including Portland (Abbott 1983). Racial segregation and tension, both in Vanport and Portland, would lead to the establishment of the Portland Chapter of the National Urban League in 1945.

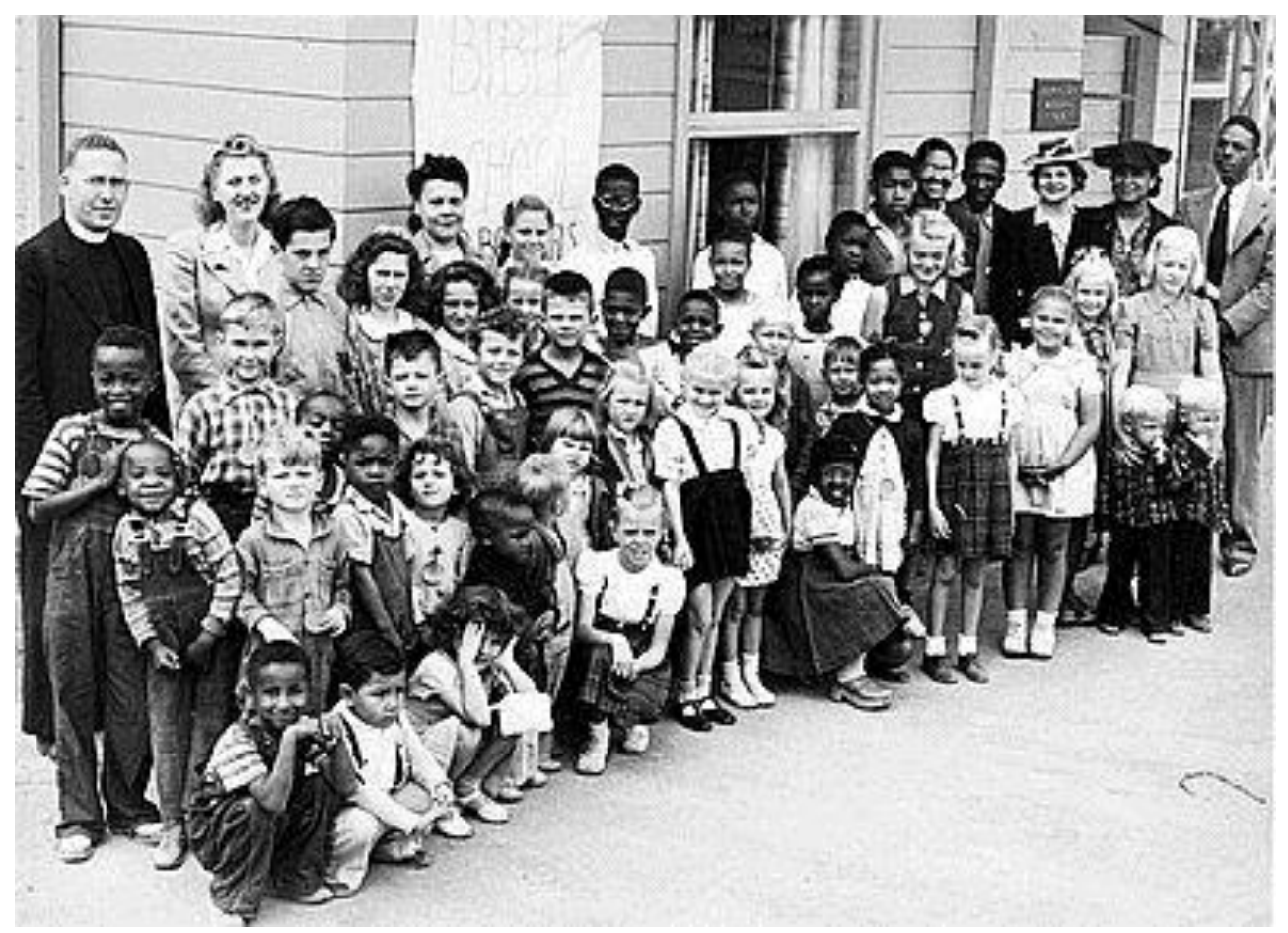

Image 7: Vanport Bible School was one of the integrated programs in the city. Source: Oregon Historical Society. 
The city's residents changed after the war; veterans and welfare recipients would begin to concentrate in the temporary housing and the African American population rose significantly: by 1945, Black residents accounted for 18\% of Vanport's population (Abbott 1983). In 1946 Vanport Extension Center, more commonly known as Vanport College, was established to serve returning veterans supported by the G.I. Bill. Vanport College would evolve into Portland State University after only one year and became a source of pride for Vanport residents.

Vanport would see its demise on May 30, 1948, when the Columbia River flooded the city in only 35 minutes. The low-quality structures, which were never meant to serve as permanent residences, were swept away. Because the flood occurred on Memorial Day weekend, many of Vanport's residents were not in imminent danger. The city's 18,500 residents fled to Portland, with African American families mostly displaced to the Albina and other areas of North Portland. Vanport College would relocate to downtown Portland and become the modern day Portland State University.
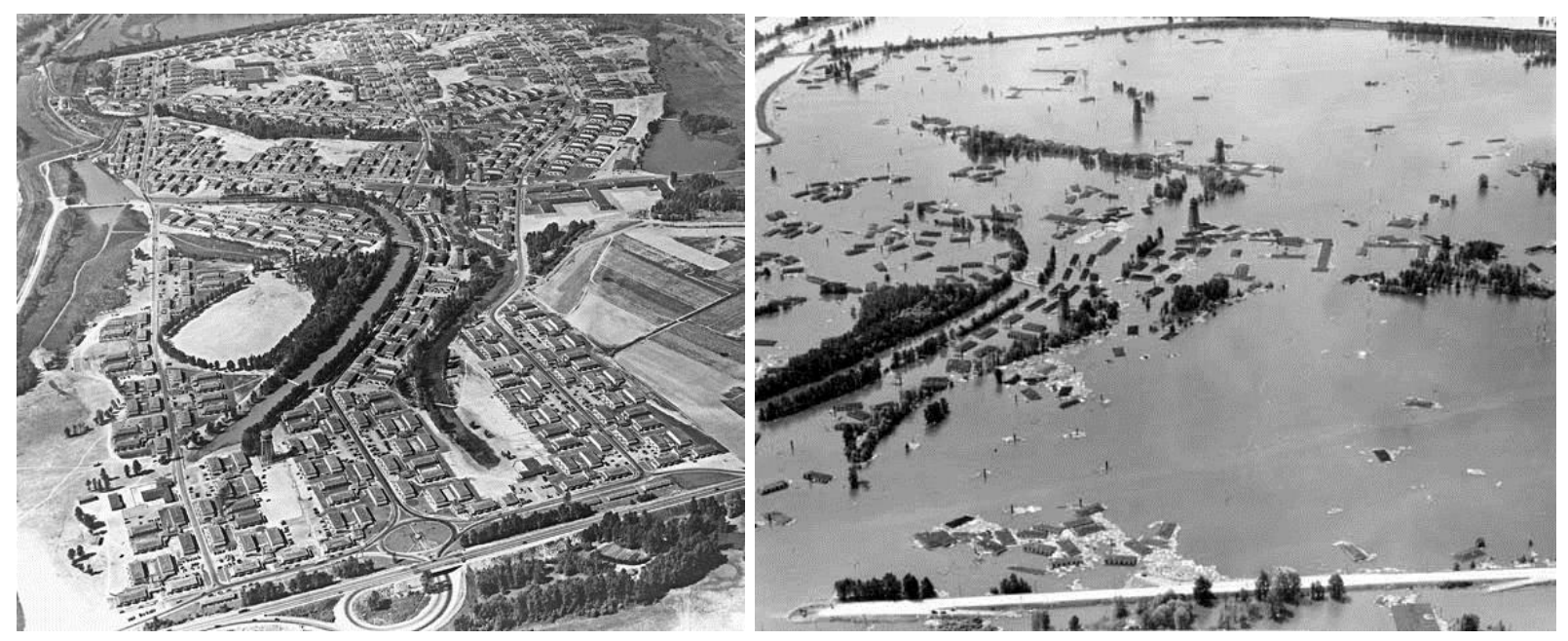

Images 8 \& 9: City of Vanport before and after flooding. Source: Oregon Historical Society (L), City of Portland Archives (R).

North Portland would be home to major urban renewal projects, further disconnecting and displacing the African American community. The Albina community became less centralized with the construction of Interstate 5, which essential severed the east and west parts of the area, and the clearing of neighborhoods for Emmanuel Hospital and Memorial Coliseum.

The remaining communities would face neglect and disinvestment from the city of Portland. The last 10-20 years has seen a dramatic change in the area following gentrification, which helped the neighborhood appeal to white residents and would in turn elevate the cost of living. Slowly, residents either chose to move or were displaced. Some may have left because 
of rising housing costs or because of the degradation of their community as more families moved to the outer stretches of Portland or nearby suburbs such as Gresham.

Portland has tried some strategies to combat displacement from gentrification; the issue is complex and at times seems out of the control of citizens and planners. Early intervention and community engagement have proven successful, as is seen in the Eliot neighborhood.

Residents were involved in the gentrification process, expressing which local businesses were essential to keeping consistency, as well as their needs, such as a public library with a large collection of books in Spanish. While the area has experienced changes, residents were actively involved from the beginning of the gentrification process which allowed for a more resilient community and resulted in fewer displaced families.

Gentrification's history and the impacts on modern U.S cities and communities is an incredibly complex issue which cannot be adequately addressed within this paper. Governing Magazine's series "The ' $G$ ' Word" is an excellent place to start for those who want to learn more about this topic.

\section{The decline of downtowns: post WWII to 1960}

Two acts of legislation would help start the degradation of America's downtowns and city centers: the Federal Highway Act of 1944 and the Housing Act of 1949. These Acts attempted to address the need for better infrastructure and more housing for cities in post WWII America and would help set the stage for the widespread creation of suburbs throughout the 1950s and 60s (Von Hoffman 2000, Weber 2013).

As the Federal Highway Act gained strength and funding, more citizens chose to live in neighborhoods and cities further away from the central city. Cities which had strong central cities in the 1950s would see their populations decrease, on average, 28 percent over the next forty years (Weber 2013). The majority of people leaving central cities were affluent and white and left neighborhoods with a decreased tax base to provide basic infrastructure maintenance and public services. Middle class and lower income white families were also encouraged to leave, as trends favored new construction outside the dense city center. The "white flight" trend would only encourage disinvestment and help to create areas which were perceived as slums or ghettos by city planners and public agencies. These areas would become targets for urban renewal and redevelopment under the Housing Act of 1949.

The economic vitality of city centers would also depreciate during this time. High property values within the central city, loss of a consumer population, and the inability for 


\section{DOWNTOWN REVITALIZED, COMMUNITY ORGANIZED}

expansion encouraged deindustrialization of city centers. America's status as an international economic leader was strengthened with the Bretton Woods agreement of 1944 (Bluestone 1983). The U.S. dollar became a worldwide reserve currency and a new international economic order was established. American corporations experienced record profits and those located within central cities were enticed to relocate to cheaper land outside the city center. Labor demands, especially within production-based corporations, would contribute heavily to deindustrialization as corporations were able to outsource labor to developing countries.

Job losses would drastically reduce socio-economic opportunities for people still living in the central city. As suburbs flourished throughout the following decades, disinvestment plagued many of America's central cities and downtowns. Crumbling infrastructure, lack of adequate housing, and decreasing economic opportunities would contribute to the decline of downtowns and central cities. It should be noted that the factors, severity, and time frame varies from city to city.

\section{Federal Renewal Programs}

National efforts to reduce blight and revitalize declining cities were put forth by federal agencies during the 50s and 60s. Two of these programs, Urban Renewal and Model Cities, would alter the face of many cities throughout the United States, for better or worse.

\section{Urban Renewal}

The Housing Act of 1949 would dramatically transform America's downtowns throughout the 1950 s and 60s. This legislation allowed cities to receive federal funding in order to clear blighted areas or slums to make way for public housing projects or other urban renewal projects. While these early urban renewal projects and plans may have benefitted some, the majority of areas cleared were home to low-income minority populations without a voice in the decisionmaking process. The areas and communities which were selected for renewal were deemed slums or ghettos; often, public housing and urban renewal only worsened conditions. In 1973 the federal funding of public housing and the urban renewal program was suspended due to widespread failure and controversies (Von Hoffman 2000).

When the federal program ceased funding in the early 1970s, the majority of funding for urban renewal project began to come from Tax Increment Financing (TIF). TIF increases taxes incrementally in a renewal area, using the revenue to pay for any improvement projects in that area. Urban renewal can also be financed through foundations or grants; although these are less likely due to the scope and time length most projects require (Weber 2013). 
Tulsa began its urban renewal efforts in 1961, two years after the establishment of the Tulsa Urban Renewal Authority (TURA). The Tulsa Housing Authority would not be established until 1967, when the program began to focus less on "slum clearance" and instead aimed to save structures as well as the communities inhabiting those areas deemed blighted (Boatman 1967). In order to appease citizen distrust in urban renewal, a committee was created to serve as liaison between TURA and Tulsans. It is unclear whether the committee members accurately represented the demographics of Tulsa in the late 1960s; what is clear is that the committee strived to represent the views of Tulsans and steer the program to focus on the "health, safety and welfare of citizens" (Boatman 1967).

TURA would only have one project complete by the time federal funding ceased. The Seminole Hills Project was a demonstration project sponsored by the National Association of Home Builders to determine the feasibility of home ownership for low-income and minority populations. Located within the Model Cities area in North Tulsa, the project would eventually create 100 new homes for families with an average monthly income of $\$ 1,700$ in 2016 dollars (Boatman 1967). Documents do not specify whether displaced African American residents were invited to lease these homes or if they were instead offered to poorer Caucasian Tulsans.

Another urban renewal project affecting downtown was slated for the Greenwood area, which was also within the Model Cities planning area (Boatman 1967). The Greenwood project was deemed too immense for one program to accomplish; a federal grant of almost $\$ 78,000,000$ (in 2016 U.S. dollars) was requested to complete the project which would affect over 1,400 families, 158 businesses, and almost 2,000 buildings, $88 \%$ of which were structurally unsound (Boatman 1967).

Urban Renewal was planned for the northwest area in downtown and was supported by Downtown Tulsa Unlimited (DTU). DTU was and continues to be the driving force for progress in downtown Tulsa and is primarily composed of downtown business and property owners (Shriver n.d). City commissioners had complete authority over the decisions regarding urban renewal. Tulsa's citizens could attend public hearings and vote in elected officials but were otherwise not involved in the planning process.

The Downtown Northwest project had three goals: widen the dwindling tax base; attract people back to the central city; and create more diverse job opportunities. An immediate issue was that, although the structures were unsound, the majority of business owners within the urban renewal area did not want to relocate to another part of town (Shriver n.d). TURA eventually forced these owners to relocate and purchased 89 acres of land in and around the 
IDL, which was surfaced and served as temporary parking structures until renewal efforts could begin (Boatman 1967).

The result of the Greenwood and Downtown Northwest urban renewal projects can still be seen in Tulsa. Both projects were halted due to lack of federal funding and left large expanses of downtown and north Tulsa barren of buildings and communities.

Urban renewal began the downtown revitalization efforts for Portland. In 1958, the Portland Development Commission (PDC) was established as the city's urban renewal agency. PDC's first project focused on the southern-most section of downtown, an area viewed by the City as "slums" which was primarily inhabited by Italian and Jewish immigrants. The South Auditorium urban renewal project displaced 2,300 residents and would lead to the eventual expansion of Portland State University. (Abbott 1997). The Emmanuel Hospital urban renewal project led to the displacement of Northeast Portland's Black communities and radically altered the landscape of

Early funding for urban renewal in Oregon was primarily from the federal government. In 1960, Oregonians voted for a constitutional amendment which authorized Tax Increment Financing (TIF). Over the 1960s and 70s the program would transition from slum clearance to neighborhood revitalization, an effort strengthened by the Model Cities Program. In 1979, Oregon's Legislature rewrote the state's urban renewal statutes. One of the major changes was improved public input of renewal efforts by requiring agencies to release annual reports. TIF uses expanded as well: communities could apply for funding economic development without housing (Johnson \& Tashman 2002).

To date, PDC has managed 25 urban renewal programs or areas: 13 of these are still active projects.

\section{Model Cities}

The Model Cities program developed from the Demonstration Cities and Metropolitan Development Act in 1966 (England 1971). The program, which was funded by the Department of Housing and Urban Development (HUD), advocated for citizen participation within government and planning projects. Government reform, institutional change, addressing poverty, and local control of federal programs were among the goals of Model Cities programs. The program addressed these goals through cooperative planning practices and more inclusive citizen involvement. Model Cities aimed to address lack of citizen participation 
Tulsa's Model Cities Program, which was started in 1968, began recommending projects in 1970. The program focused on North Tulsa, where $70 \%$ of the population was African American, followed by "Indians, Mexican-Americans, and disadvantaged whites" (England 1971). Although city leaders explained that their program was focused Tulsa's most underprivileged citizens, there is no reference to why this area was so severely neglected. It is not difficult to come to the understanding that the same areas affected by the 1921 Race Riots were also the same areas selected for the Model Cities program.

The program had three focuses: economic projects, social and community services, as well as physical planning. Tulsa's program was optimistic; many of the projects were developed successfully however they failed to create permanent, long-lasting change.

"Model Cities has made progress in all goals mentioned, however it must be recognized that those participating in Model Cities planning can provide no magic formulas, nor can Model Cities be expected to be all things to everyone. It is a beginning toward a more meaningful approach to urban problem solving in Tulsa" (England 1971).

The difficulty in assessing Tulsa's success with the Model Cities program, as well as the urban renewal program, lies in the lack of data and historical resources. Many of the articles, academic papers, and early planning documents of the 1950s-70s, if still in existence, can only be obtained in person from Tulsa City Library's archive department. The department is in the process of digitizing all archives yet it is unknown when these documents will be more readily available.

Portland's Model Cities Program began in 1968 and acted in conjunction with Portland Development Commission's Urban Renewal programs and areas. The program helped train a generation of community leaders. It was one of two civic bodies at the time which had Black representation. Through the program, the City of Portland established citizen-based committees that helped organize communities around planning and policy issues. These committees and community leaders would stretch further than the Model Cities program's designated areas; citizen outreach and organizing began to spread throughout the city (Johnson 2001).

Portland's application for Model Cities funding identified multiple problems they wanted to address. These problems stemmed from a low number of organizations focused on participation, as well as general disinterest in planning or understanding the issues of the city. Communication between the existing groups needed to improve and the city wanted more citizen involvement both in these organizations and throughout the city (Johnson 2001). 


\section{DOWNTOWN REVITALIZED, COMMUNITY ORGANIZED}

In 1974 the Model Cities Program was discontinued. The physical outcomes were outweighed by the important role it played in developing citizen involvement and participatory planning policies in the city. Portland's current neighborhood structure and the Office of Neighborhood Involvement (ONI) are examples. Portland's participatory planning history is discussed in more detail later.

\section{Early revitalization efforts}

The Tulsa Metropolitan Area Planning Commission (TMAPC) was established in 1953 to serve as the city's official planning department. In 1960, TMAPC partnered with Tulsa Urban Renewal Authority (TURA) to create the first Tulsa Comprehensive Plan. The main purpose for creating the Plan was to receive federal funding for urban renewal projects (Ambler 2009). The 1960 s and 70s were years of demolition, especially of residential units, in order to create a blank canvas for urban renewal projects.

Tulsa's regional planning efforts were strengthened with the creation of Indian Nation Council of Governments (INCOG) in 1967. INCOG is an association of both city and tribal governments and "provides planning and coordination services to assist in creating solutions to local and regional challenges in such areas as land use, transportation, community and economic development, environmental quality, public safety, and services for older adults" (INCOG n.d).

Tulsa's revitalization and planning efforts were weakened after the failed revitalization attempts through Urban Renewal and the Model Cities program, however a few projects focused on the business sector were completed in the 1970s; these would help to keep downtown economically stable. By 1980, 46,000 Tulsans were employed in the city center; in comparison, downtown was home to only 2,760 Tulsans. (TMAPC 1980).

According to the U.S. Census, downtown Tulsa saw a 31\% decrease in population density from 1970 to 1990; during the same time period, the percentage of African Americans living in downtown rose from 3.7 percent to 22.6 percent (Social Explorer n.d). This data suggests that Tulsa's downtown was experiencing a loss of middle and upper-class White citizens who were choosing to move out of the degrading central city for new suburban neighborhoods or nearby cities.

Tulsa's Comprehensive Plan would receive a major update in 1978, when then-mayor Robert LaFortune spearheaded Vision 2000. The plan focused on balanced growth among urban and suburban areas of Tulsa and aimed to provide more opportunities for citizen action and participation (Pearson 2000). Public opinion is still split on whether or not the plan would 


\section{DOWNTOWN REVITALIZED, COMMUNITY ORGANIZED}

accomplish these goals in an effective and inclusive manner: while it did give Tulsans and opportunity to get more involved, only a small set of Tulsans got involved. Those who did were self-motivated and aggressive in their opinions; participation support systems were not introduced, so those who were active were most likely residents with pre-existing levels of authority.

In the 1960s and 1970s, Portland decided to take a very different direction than the rest of U.S. cities: instead of sprawling further away from the center, Portland planners and its dedicated citizens focused on invigorating its downtown and central city. Economic and social efforts would create a thriving hub for the city while cities of similar size were watching their downtowns crumble from disinvestment and abandonment. Throughout the late 1970s and 1980s, an innovative transit mall was introduced into downtown Portland with a network of buses, streetcars, light rails, and cars to connect more areas in the region.

Many of these early changes were brought on by Portland community organizers; this fierce citizen force showed the strength that civic engagement has to change policies and practices in their city government. Throughout the 1960s as communities organized so did city government and politics. Neighborhood associations and citizens committees established themselves in each district of Portland and were seen as integral players within local and city planning. When Paul Schulze took over the Model Cities program in 1968, his intentional decision to value citizen input over public agencies showed city planning's understanding that the opinions of citizens were essential (Abbott 1983).

For Portland, downtown revitalization was not an end result of years of poor choices; instead, it was an amazing moment of foresight into where the future of cities would and would not move. The desire for more inclusive and progressive planning and politics was not a Portland phenomenon: many of Portland's neighboring cities, such as Beaverton and Hillsboro, were also similarly motivated. The region's citizens and elected officials desired to establish a greater connection between cities both at a planning level and also with the region's goods and services. Metro was formed in 1979 to serve as the regional government (Abbott 1991). Metro, among other things, provides regional planning data, a platform for regional leaders to discuss issues both at a city- and regional-level, and is responsible for the regional park, greenways, garbage and recycling management, and trail system. Metro is also responsible for special venues such as the Oregon Zoo and Convention center, as well as regulating Portland metropolitan area's Urban Growth Boundary. 


\section{CURRENT DOWNTOWN ENVIRONMENT}

\section{Downtown Tulsa}

Downtown Tulsa is located in the center of Tulsa and serves as central hub between East, West, South and North sections of the city. The area is completely within Census Tract 25 and is contained by a system of highways known as the Inner Dispersal Loop (IDL). The Arkansas River is directly southwest of Downtown. There are six distinct districts located within the IDL. BOK Center district is most often utilized for large-scale entertainment. The Deco District is the economic and government center for downtown. The Blue Dome District is home to many small businesses focused on local products. The Greenwood District is most known for the ONEOK field and OSU Tulsa, but also serves as a reminder of the Tulsa Race Riots. The Brady Arts District is the primary location for new housing and development. Not pictured is the new East Village District, south of the Blue Dome and west of the Deco District, which is being marketed towards empty nesters.

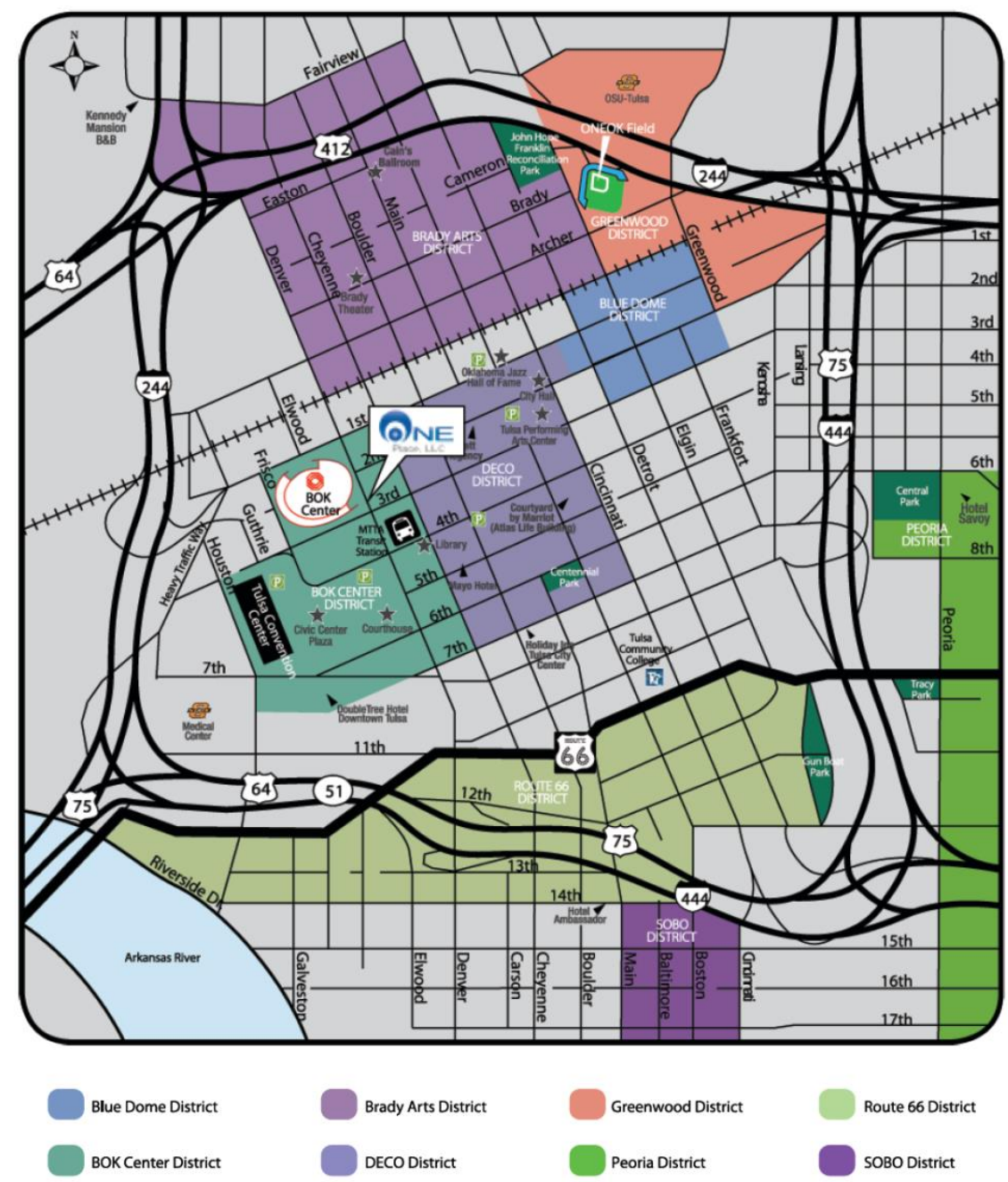

Image 10: Downtown Tulsa and Districts. Source: Paine \& Associates (2015) 
Three districts are located outside of the IDL but still within the Planning Area of Tulsa's Downtown Area Master Plan: Peoria (Pearl) District, SOBO District, and Historic Route 66 District.

Downtown is surrounded by neighborhoods that primarily serve low-income, working class families. These neighborhoods have faced disinvestment alongside downtown and are ripe for redevelopment as city-wide interest to revitalize Downtown Tulsa grows. They are included with downtown as areas of new growth in the 2010 Comprehensive Plan.

Downtown Tulsa's demographics vary from the city in a few major ways. Downtown Tulsa's African American population is over 10\% higher than the city's, however Tulsa has an overall more diverse population. Downtown Tulsa is home to more young people aged 20-34 and renters account for almost $85 \%$ of residents.

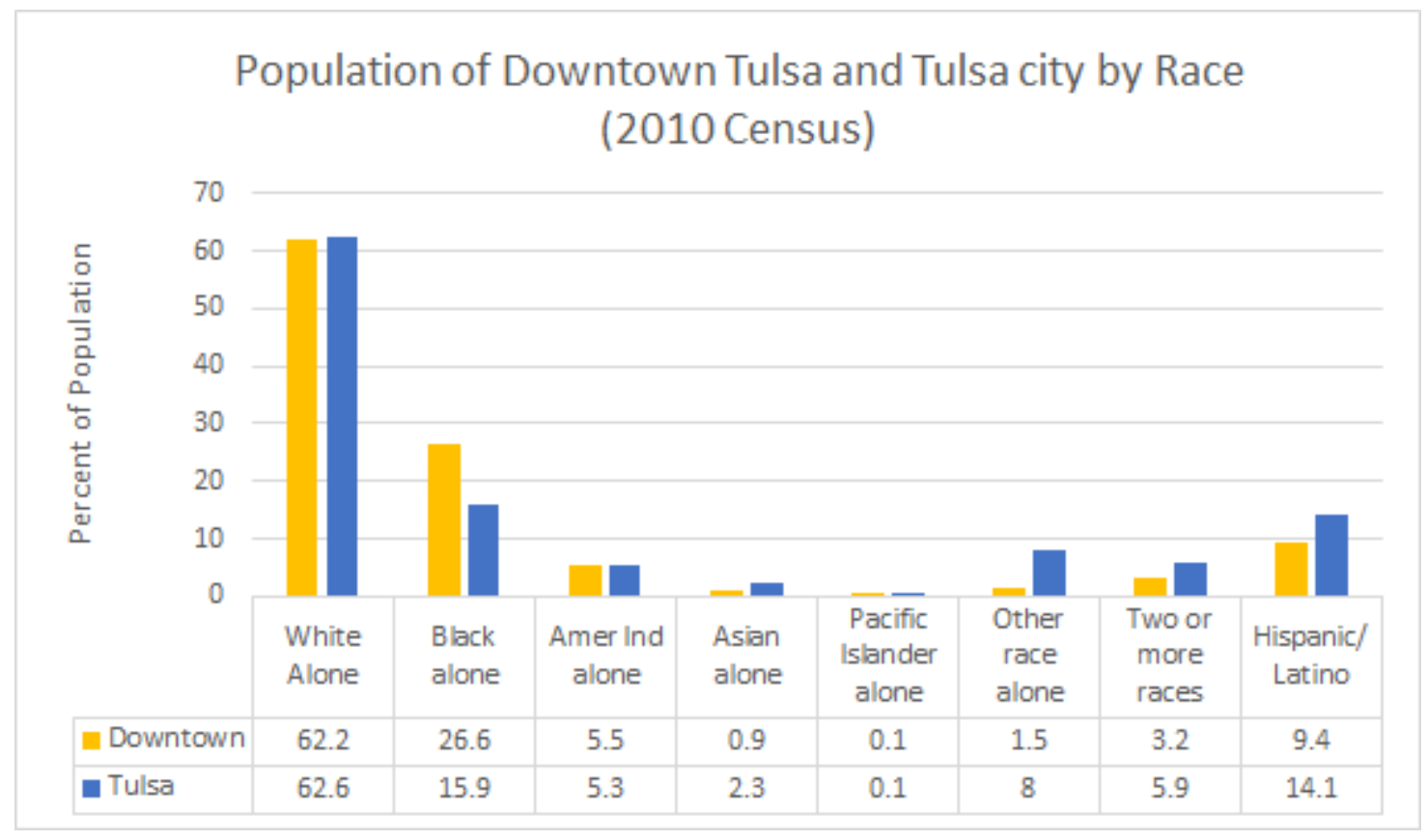

Table 3: Comparison of Downtown Tulsa and Tulsa City by Race. Source: U.S. Census (2010)

While data may suggest that young people are the majority of residents in Downtown Tulsa, it is necessary to also examine that Tulsa's county jail, David L. Moss CJC, is located within Census Tract 25. Inmates are classified under "institutionalized population" in the U.S. Census: this category comprises adults or juveniles living in correctional facilities, nursing homes, psychiatric facilities, or in-patient hospice care (US Census 2016). Inmates are not counted by their original address but by their current address. 
DOWNTOWN REVITALIZED, COMMUNITY ORGANIZED

$\begin{array}{lrr} & \text { Tulsa City } & \text { Downtown } \\ \text { Total Population } & 391,906 & 3,980 \\ \text { Institutionalized Population } & 4,284 & 1,836 \\ \text { Percent of Population by Age } & & \\ \text { 20-34 years } & 22.9 \% & 40.5 \% \\ 35 \text { to } 54 \text { years } & 25.7 \% & 30.5 \% \\ \text { Under } 18 \text { years } & 24.5 \% & 3.4 \% \\ \text { Table 4: Population by Age and Institutionalized for Tulsa City and Downtown. Source: U.S. Census (2010) }\end{array}$

Although David L. Moss CJC serves as a temporary location for inmates before relocation or release, this population is still reflected within Census demographics and may lead to misrepresentation of Downtown's Tulsa's residents. Further demographic information on inmates is needed to better understand whether the higher amounts of young people, males, and African Americans are due to the jail's location in Downtown Tulsa. 


\section{Portland's Central City and Downtown}

In 1988, the City of Portland adopted its Central City Plan. This signified a shift from focusing on individual areas within the central city to promotion of an inter-connected urban core. Downtown became one of seven districts of the Central City Plan area. The seven districts have been reorganized into four quadrants for the Central City Concept Plan (2012): Northwest, North/Northeast, Southeast, and Southwest. There are separate Quadrant Plans, excluding Southwest, which focus on issues and concerns specific to those neighborhoods and areas (see Image 11).

Portland's Central City Plan would help connect the urban core to suburban neighborhoods, as well as the often neglected neighborhoods closest to the urban core. Portland's Central City Plans (1988, 2012) place importance on the 1972 Downtown Plan, which laid out community goals and planning policies still present in Portland. Some concepts which grew from the 1972 Plan include: a transit mall which would become the backbone of downtown; creation of an east-west retail core; replacement of a riverfront freeway and regained access to river parks; preservation of special and historic places. The concepts, goals, and principles of Portland which shaped Downtown in the 1970s and 80 s will be discussed in more detail later.

Portland's Central City, as opposed to just Downtown, was chosen for this study for two reasons. Firstly, the City of Portland has focused on the Central City area for almost 30 years; although it would be possible to find planning documents and research devoted to Downtown, this would not represent the current trends of the city. Secondly, the City of Tulsa has expressed a desire to create a greater connection between its downtown and neighboring areas, including the Arkansas Riverfront. 


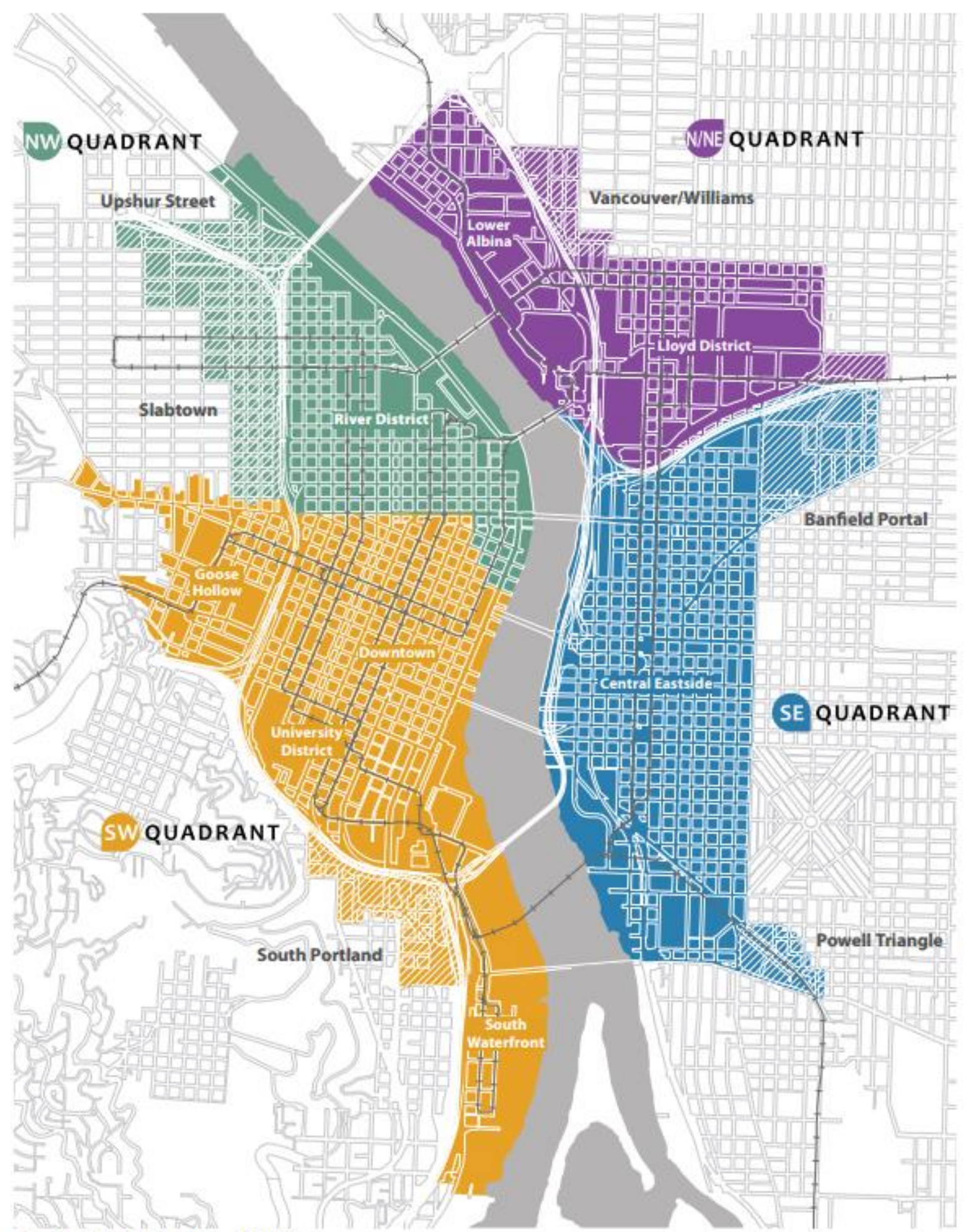

Central City Quadrants and Districts.

Source: Portland Bureau of Sustainability Central City Concept Plan (2012) 
Downtown Portland is located in the Southwest Quadrant of the Central City and is defined by the following boundaries: Interstate 405 (West/South), Burnside Street (North), and the Willamette River. Downtown is still considered the economic hub for the Central City and the region. It serves as a destination for locals and visitors due to its immense variety of goods and services offered. Portland Transit Mall is also located in Downtown, as well as in the University and River Districts.

Directly south of Downtown are two districts focused on education and innovation: University District and the South Waterfront. Portland State University and Oregon Health Sciences University are the anchoring institutions for these districts. University District is often viewed as a part of Downtown because of its encapsulation within Interstate 405 to the south.

Goose Hollow, located west of downtown, is primarily a residential district. Providence Park is one of the defining landmarks of the district and is the home of the Portland Timbers MLS and Portland Thorns FC soccer teams.

The majority of the River District is two neighborhoods: the Pearl District and Old Town/Chinatown. These neighborhoods are characterized by repurposed warehouses, yet their use of these spaces varies greatly. The Pearl District began as an artists' community and revitalization of the area began in the 1980s and 90s. The Pearl is still home to art studios and galleries; the housing has transitioned to luxury townhomes and apartments. Old Town/Chinatown contains multiple social service agencies, shelters, single-room occupancy hotels, and most notably Right 2 Dream Too, a non-profit housing program operated by Portland's homeless community. The area is also known for its nightlife and many of the warehouses have been converted to dance clubs.

Central Eastside, Lloyd District, and Lower Albina are all located east of the Willamette River. These areas were historically used for commercial and industrial purposes. Public transit projects have increased accessibility to the area. Zoning that has encouraged diversification of uses have helped to draw people into the areas. Oregon Museum of Science and Industry (SE Quadrant), Oregon Convention Center (NE Quadrant), and the Moda Center (N Quadrant) are prominent landmarks of these areas. 


\section{DOWNTOWN REVITALIZED, COMMUNITY ORGANIZED}

The Central City covers many census tracts, making data collection and research incredibly complex. The Central City Concept Plan (2012) gives a brief demographic makeup and current conditions of the Central City:

- Central City has a population of 32,000 or $5.5 \%$ of Portland's total population.

- Over 127,000 employees work in the Central City;

- 35 percent of jobs in Portland;

- 13 percent of jobs in the region.

- Over 26,000 students attend college in the Central City.

- Roughly 80 percent of housing units are 0-1 bedroom units.

- Over 50 percent of rental housing is considered affordable to households earning less than $60 \%$ of Portland's median family income.

\section{Office environment}

Downtown Tulsa and Central City Portland serve as the government and economic business centers for the cities. While Downtown Tulsa may not be as economically diverse as Portland's Central City, many of the city's larger employers, developers, and government entities are located within the Inner Dispersal Loop. Downtown Tulsa has in the past been considered a " 9 to 5 " downtown, where the majority of people using the area are white collar workers. In the past few years there has been a push to have more diversity in employment options, such as the rise in retail and service industry businesses. The goal of creating a more active downtown during evenings and weekends is supported by Tulsa's Downtown Area Master Plan (2010).

Central City (CC) Portland is home to the traditional "9 to 5" workers, as well as the creative class. Downtown Portland tends to become less active at night than other areas such as the Pearl District and Old Town Chinatown. Technology startups, design firms, and craft studios are prevalent throughout the area. While there is a population who only inhabit CC for employment, many of these employees live in nearby neighborhoods, including the CC, or stay in the area after work to benefit from the myriad of excellent restaurants, social events, or happy hours within a few blocks from their workplace. 


\section{Art and culture}

Both Tulsa and Portland place an emphasis on arts and culture in their downtown. Multiple galleries, museums, and concert halls are located in the downtown area. Downtown Tulsa has always been a place for artists due to the affordable rent and eclectic architectural styles. The artist community has decades of experience living and working in downtown, an area that until recently was completely undesirable by the majority of the population.

In the past few years, the artist community has become more centrally located around Archer Avenue in the Brady Arts District. The Brady District is home to Tulsa's First Friday Art Crawl. Tulsa Artists Coalition (TAC), Philbrook Museum Downtown, Living Arts of Tulsa and Arts and Humanities Council of Tulsa are just a few organizations that are situated in this district. These organizations are all located near downtown Tulsa's two parks, Guthrie Green and John Hope Franklin Reconciliation Park. Guthrie Green, a former brownfield site, often serves as an outdoor space for events, including yoga, movies, concerts, and other community events.

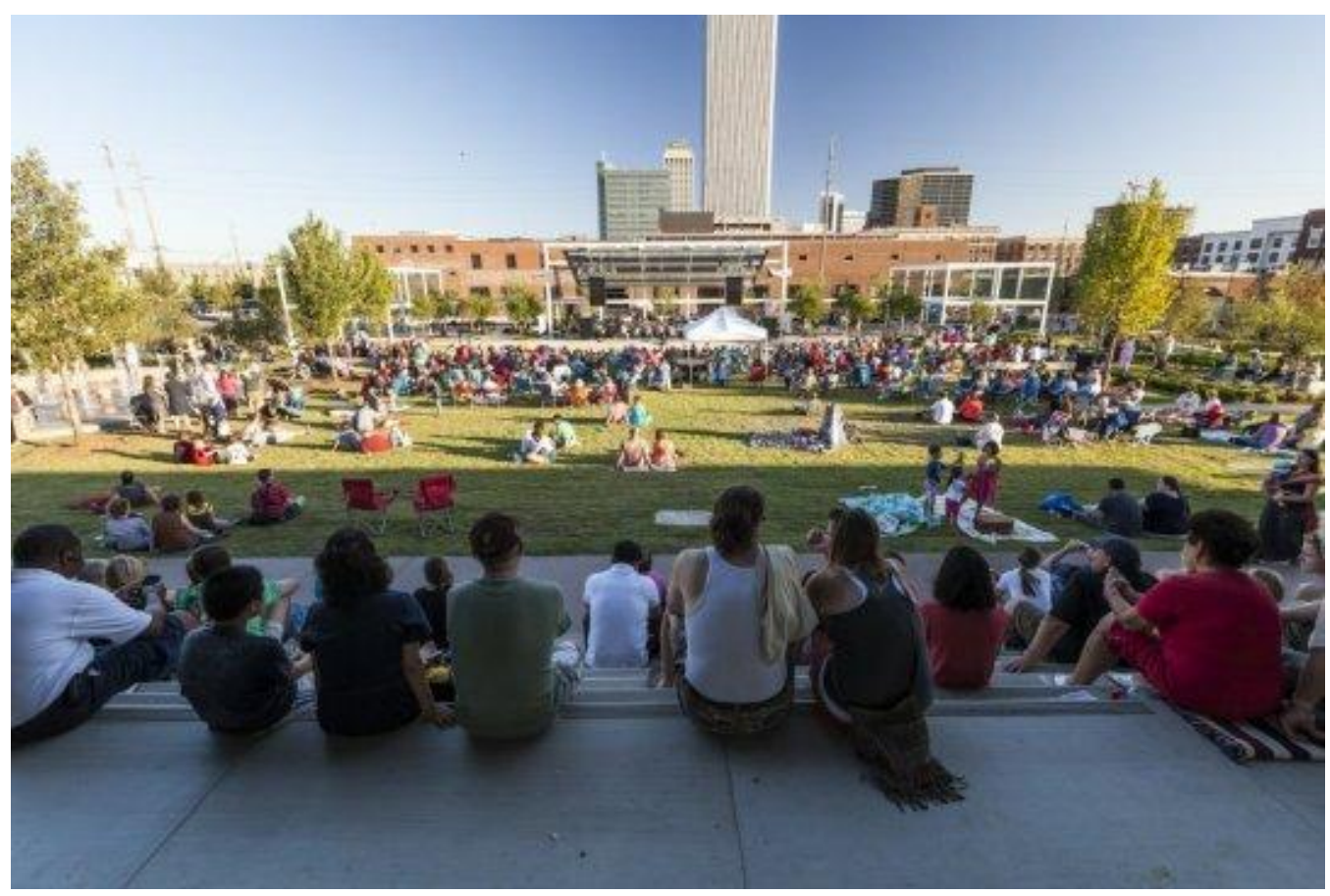

Image 12: Tulsans gather at Guthrie Green for one of their summer concerts; the "urban garden and performance space" opened in the fall of 2012. Source: guthriegreen.com

In CC Portland, arts and greenspace go hand in hand: some of these art spaces are located on the South Park Blocks, a park which is a city-block wide and stretches for twelve 
blocks. Oregon Historical Society, Portland Art Museum, and Arlene Schnitzer Hall are all located on the park blocks, which end at Portland State University. The South Park Blocks are also used for farmer's markets. The collusion of arts and park space seems to be a natural partnership, which can be seen with multiple sculptures lining the park blocks.

Along the North Park Blocks, the Pearl District began as a solace for the artist community. The renovation of old warehouses into loft spaces and gentrification of surrounding buildings has created a neighborhoods more suited for upper-class residents, however the area still retains its emphasis on arts and culture. This area hosts "First Thursday", which allows for a neighborhood-wide art gallery opening and fills the area with both residents and visitors alike.

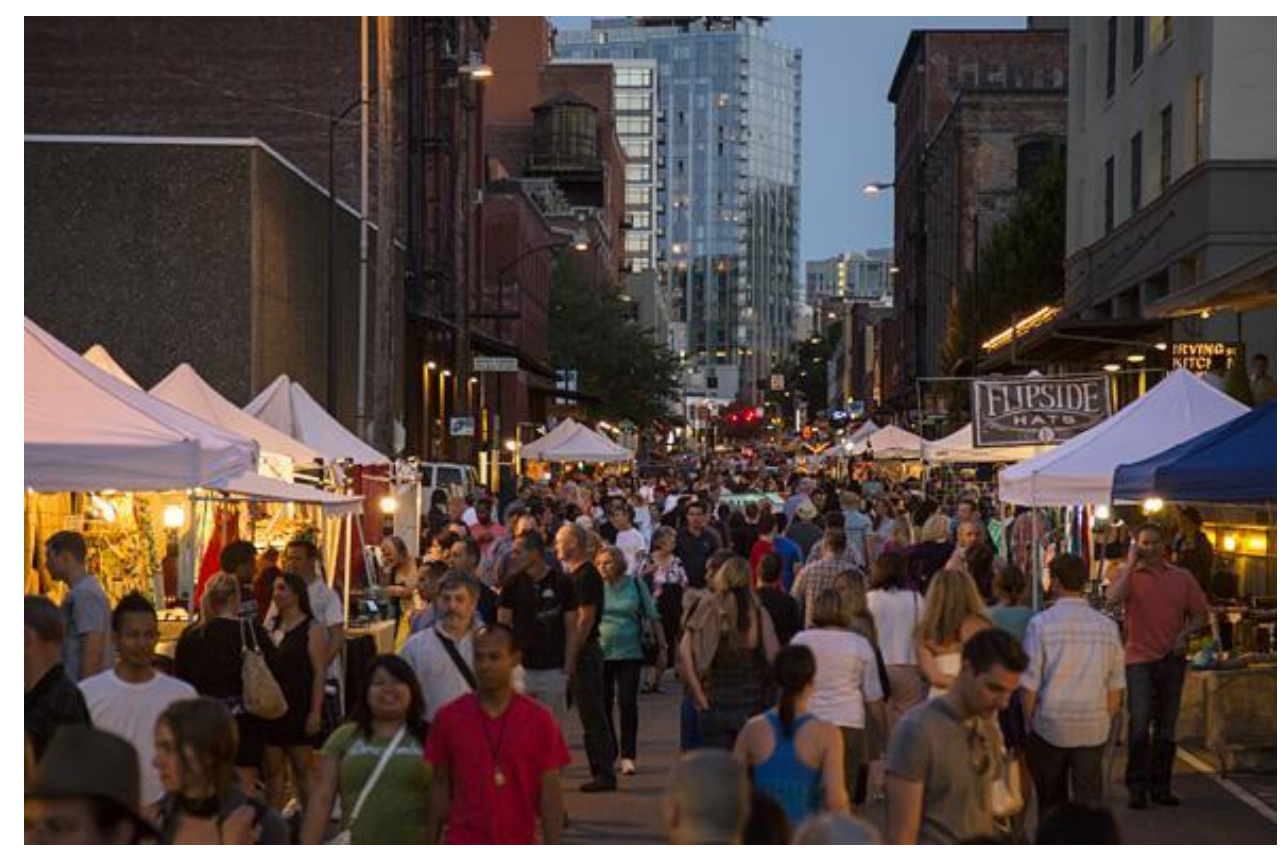

Image 13: Portlanders enjoying a summer evening during First Thursday, a Portland tradition for over 25 years.

Source: explorethepearl.com

\section{Social elements}

Tulsa has seen an increase in social activities in their downtown area since revitalization began in 2010. Young people are eager to create a downtown environment that matches their aesthetic; they are helped by Tulsa Young Professionals (TYP), a well-organized nonprofit that has spoken for young people on many issues surrounding downtown. TYP also hosts events which encourage people to be a part of downtown and other growing parts of Tulsa. Many of the new businesses in downtown are locally owned, with products crafted by Tulsans.

Another group of people involved in downtown are empty nesters desiring to return to the inner city. East Village is being marketed toward this demographic and town homes are 
under construction. It is unknown how the rise in empty nesters will alter social life in downtown but for now the spirit in downtown is vibrant and young. Public transit in downtown is not necessarily geared towards social uses; in the past few years Uber and Lyft have become an essential resource for people so they can get home safely after their evening out.

Portland's Central City (CC) has a variety of social uses. Many people consider the area a destination for social events or nights out. Restaurants, bars, nightclubs, and coffee shops are heavily scattered throughout the area and are frequented by the old and young alike. Because CC Portland has more housing available for rent or sale than Downtown Tulsa, there is more activity at night and on weekends.

Portland's emphasis on Central City instead of just the downtown area helps accommodate more people and their unique desires for a downtown area. Each district has a unique feel and a different type of social atmosphere. The CC is well connected to the rest of the city by public transit, which allows for Portlanders to enjoy their evening without relying on a car and assures them a safe and lawful way home.

\section{Transit}

Downtown Tulsa is encapsulated by the Inner Dispersal Loop (IDL), which prioritizes automobiles as the primary form of transportation to and from downtown. Street and surface lot parking is available, and some businesses offer shuttle services from lots outside of the IDL to their employees. Tulsa is transitioning to a paid street parking system in busier areas.

The Metropolitan Tulsa Transit Authority (MTTA) launched in August 1968. In 1998 Denver Avenue transit center was built downtown to serve as the hub for bus travel; three years later another station was built to improve transit from South Tulsa (where the majority of suburbs are located) and downtown (Tulsa Transit n.d). The majority of bus lines pass through downtown; in order for transfers to occur, riders must travel to the Denver Avenue transit center.

The City of Tulsa hopes to strengthen its bus system in order to provide a reliable, attractive alternative for auto drivers. In 2011, the Indian Nation Council of Governments (INCOG) released its FAST Forward Plan, the first regional-transit plan for the Tulsa metropolitan region. For the project, a mobile outreach bus traveled across the region in order for INCOG to better understand the opinions of stakeholders and educate citizens on what a regional transit system could bring to the area. Over four months, FAST's outreach bus traveled to 117 locations, often libraries, schools, and community centers, and received over 1,500 surveys. 


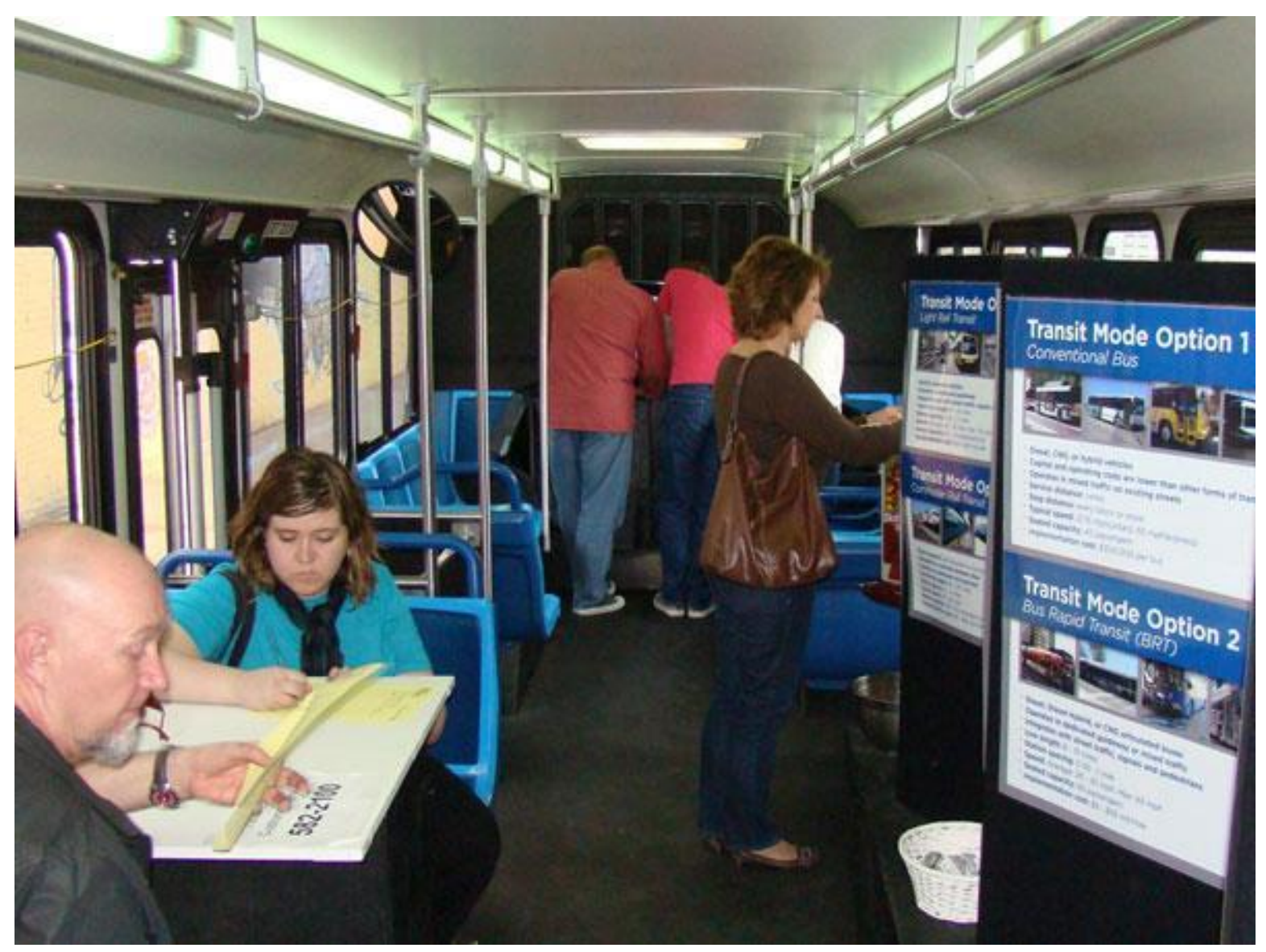

Image 14: FAST Forward participants were able to speak with staff and voice any concerns or questions regarding the plan. Educational resources were provided. Source: American Planning Association (2012).

The overwhelming majority of respondents agreed that a better transportation system would have both environmental and economic benefits to the area; it was also agreed upon that elected leaders should be encouraging alternative transit development (INCOG n.d). In 2012, The FAST Forward Mobile Outreach Bus received the American Planning Association (APA) National Planning Award for Public Outreach.

Pedestrian traffic may be seen in more active districts, such as the Deco District and the Brady Arts District but overall walking is not common. It is difficult to travel across downtown on foot, especially for those not able-bodied. Currently there is no regular bus or streetcar which travels throughout the IDL to facilitate pedestrian travel.

Biking in Tulsa is slowly becoming more common, however downtown is not currently equipped to address the safety issues of bikes on roads, nor is there reliable bike parking throughout downtown. Tulsa Townies operates a bike rental station just outside of the IDL which is marketed towards riverfront travel. Bike transit to downtown from this area is difficult and dangerous. 
Portland's central city is accessible by automobile, however it is not the overwhelmingly dominant transit choice as seen in Tulsa. Interstates 405, 5, 84, and Highways 99, 30, and 26 help to circulate traffic around the central city. Parking is not as abundant in the inner city; the majority parking is paid and monitored. For those areas in which parking is non-metered, residents of the area can apply for parking permits which help to control commuter parking. The City of Portland owns and operates six SmartPark garages, three of which are equipped with electric vehicle (EV) charging stations. These, along with other private parking garages, often have retail or restaurants along the first floor, which further encourages community interaction (City of Portland Bureau of Transportation 2016).

TriMet serves the greater Portland metropolitan region through a system of buses, streetcars, and light rail. Portland has historically been a city ahead of the curve: in 1893, it became to first U.S. with an interurban electric streetcar (TriMet 2015). Ridership declined after WWII when automobiles began to dominate. Tri-Met was created in 1969 in order to replace individual cities' bus lines with a regional system. The community organization against the Mt. Hood Freeway would push the need alternative transit to the forefront of city issues and TriMet would be further strengthened.

The Portland Transit Mall was approved by City Council in 1972 and was opened in 1978 (TriMet 2015). The Mall, a 22-block stretch of one way streets on 5th and 6th Avenue, attracted citizens with its efficient transit flow, the flourishing businesses, and community spaces that lined the streets. The Portland Mall still serves as a hub for public transit, however it is by no means the only transit hub in Portland and riders have more access to transfers without needing to travel to downtown.

In 1986, the Ride Connection organization was established in order to coordinate transportation options for riders with mobility issues that utilize TriMet's LIFT program. The LIFT program operates during daily transit hours; riders are also able to schedule a LIFT for the following day. In order to ensure inclusive access for riders, all buses are equipped with access ramps and priority seating which can be lifted to create enough space for two mobility devices. All MAX lines, streetcar, and buses come equipped with ramps and priority spaces. Portland Mall transit stops are equipped with digital displays with audio, as well as information in Braille (TriMet 2015). 


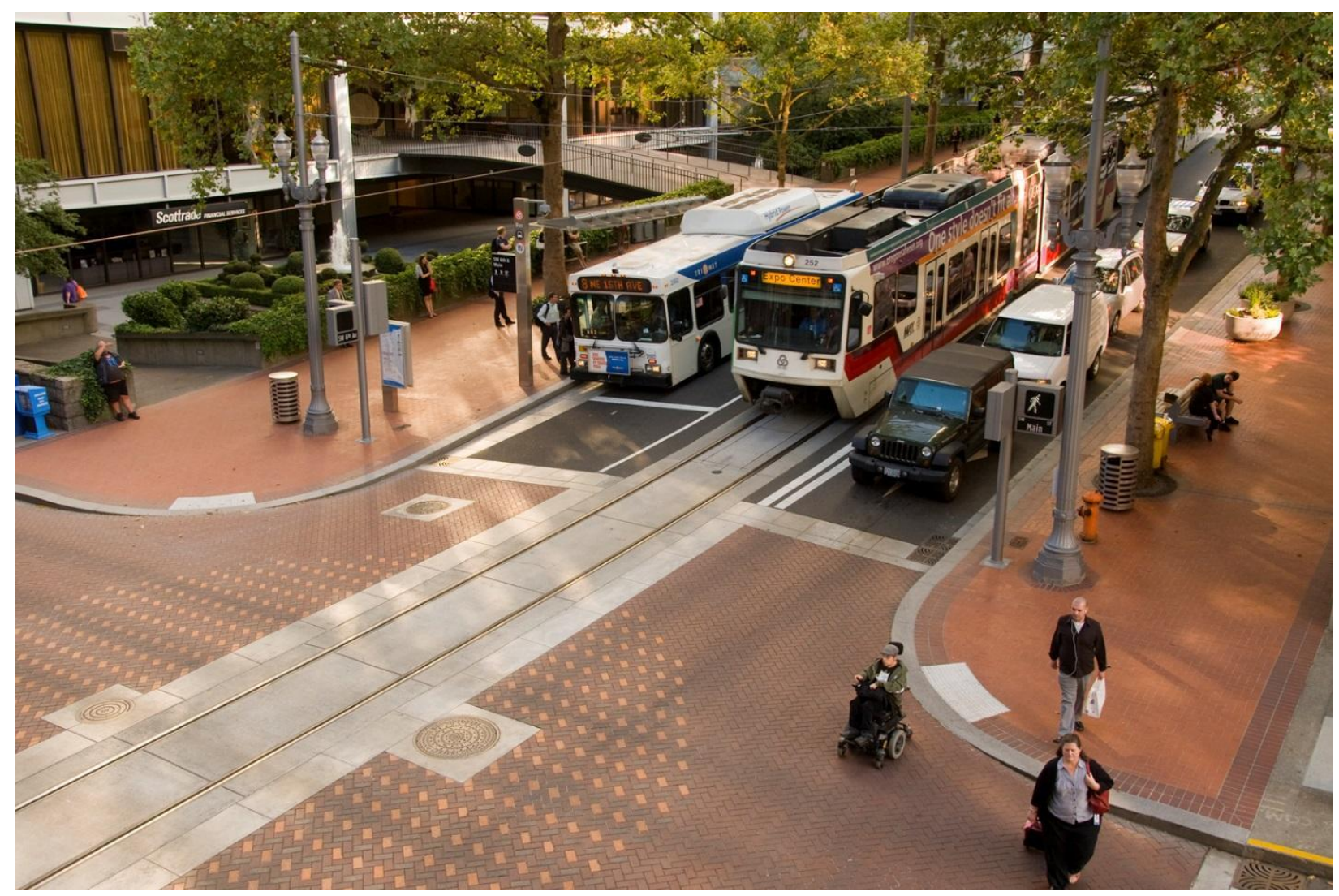

Image 15: Portland's multi-modal Transit Mall in 2014. Bicyclists tend to travel on other streets nearby. Source: TriMet

After almost a decade of planning and construction, the Metropolitan Area Express (MAX) began operating in 1986 and connected a 15 mile stretch from Portland to Gresham. Interest in an inner-city transit option became apparent, and in 2001 the Portland Streetcar began operation from Portland State University towards Northwest Portland. In 2009, work began on the Central Loop project, which would create more connections between the east and west sides of the central city (TriMet 2015).

In general, Portland's central city is walkable. Bridges connecting across the Willamette are equipped with both bike and pedestrian lanes. The Portland Streetcar assists in the flow of pedestrian traffic and is also a reliable source of inner city transit for the less able-bodied and sidewalk beautification projects have led to friendly and inviting streets for pedestrians.

The majority of Portland's central city is accessible by bike. Bike lanes are common on major thoroughfares and may be painted green or with bike symbols to increase automobile awareness. At stop lights, bicyclists are able to stop in a designated space in front of traffic, which helps to reinforce their presence and safety when the light turns green. Bike parking is abundant; businesses create unique parking structures that engage citizens, such as a giant whisk outside of a cupcake shop. 


\section{DOWNTOWN REVITALIZED, COMMUNITY ORGANIZED}

Portland's most recent effort to increase inclusive transit is the Tillikum Crossing: Bridge of the People. It is the largest car-free bridge in the United States and was the final integral piece to connect the southern section of the Central Loop. Buses, streetcars, MAX lines, bicyclists, and pedestrians are all able to cross the Willamette as of 2015.

\section{Current downtown revitalization efforts}

In 2010, the City of Tulsa adopted Tulsa Downtown Area Master Plan. The plan, which replaced the 1980 District 1 Plan, reinforced the already present grassroots movement to bring activity and vibrancy back into downtown. Private developers have begun work on housing both for rent and sale; these developments range in price and are scattered throughout the Inner Dispersal Loop. Small business owners are moving back into the historic main street buildings that have been vacant for years and are helping to create distinct personalities for each of downtown's districts. Citizens and nonprofits are helping to reinvigorate the culture and community with art installations, street fairs, and other events that aim to gather Tulsans in downtown.

Tulsa Young Professionals (TYPros) was launched in 2005 by Tulsa Regional Chamber in order to attract and retain young people to the area. In 2014, TYPros began to focus on downtown more with the Golden Crater design contest, which asked applicants to rethink parking lots in the downtown area. They would choose downtown as the sight of their fourth Street CReD (Community Redevelopment) event, which would block off 18 blocks and bring 2,500 Tulsans and show city leaders that the area still has interest from the community and potential for reinvestment (Vincent 2014). 


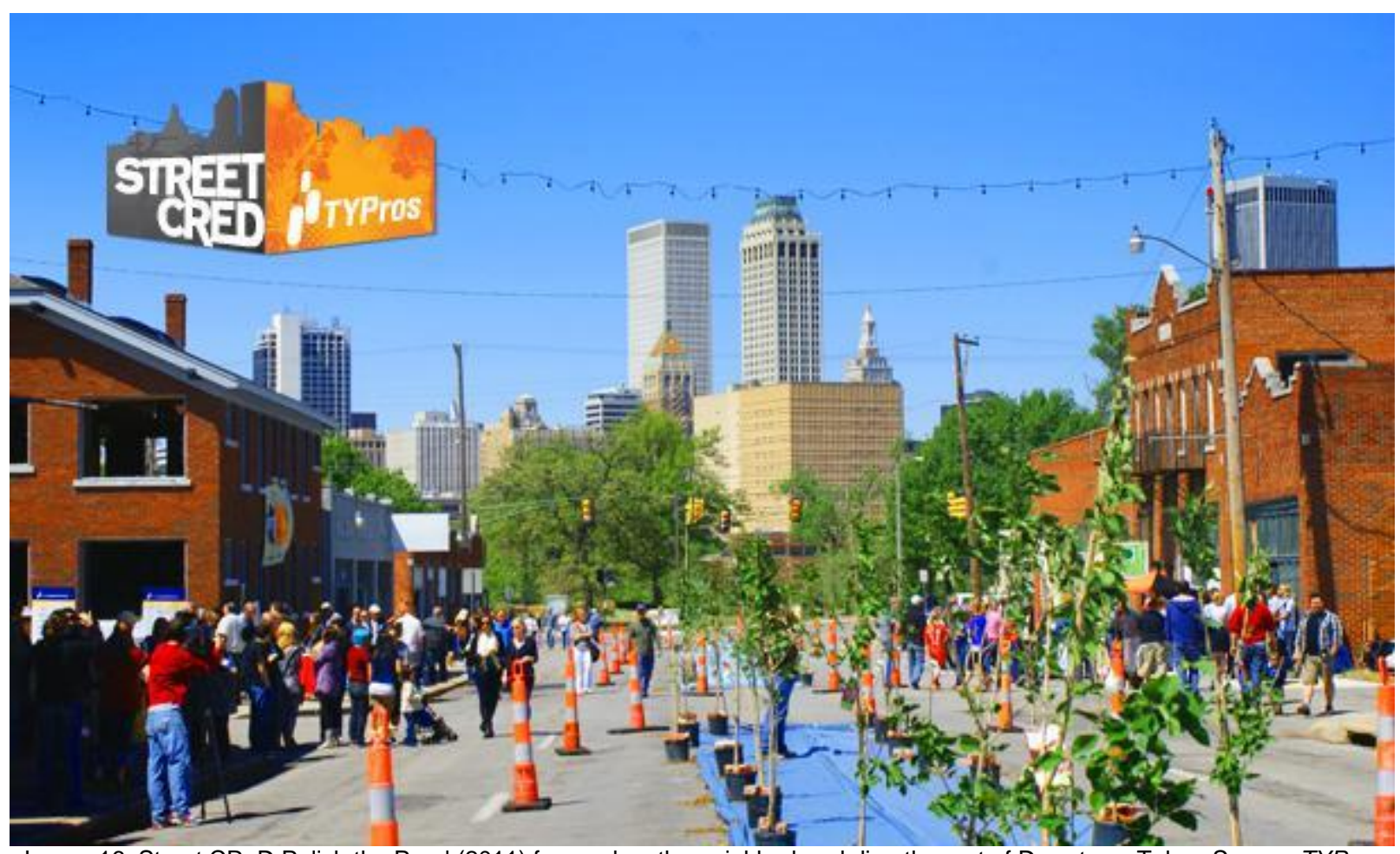

Image 16: Street CReD Polish the Pearl (2011) focused on the neighborhood directly west of Downtown Tulsa. Source: TYPros

There are a variety of projects in progress or planned for the Downtown area. Since 2009, 27 projects have been completed in Downtown Tulsa, with 28 projects either planned or under construction (Downtown Coordinating Council 2016). Tulsa's Downtown Coordinating Council, an advisory board of the area's property owners, "works to actively develop Downtown Tulsa as a vibrant center of commerce, arts, entertainment and education (Downtown Coordinating Council 2016)." Their website serves as engagement tool for downtown development and posts events and meetings as well as current projects and reports.

As of June 2015, Downtown Tulsa had a total of 2,130 housing units either planned, existing, or under construction/renovation (Downtown Coordinating Council 2016). It is unspecified whether or not new housing will be affordable to young people and working class families, two demographics Tulsa hopes to attract back to the downtown area. The majority of properties for rent are located in the Brady Arts District and the Deco District. 
DOWNTOWN REVITALIZED, COMMUNITY ORGANIZED

\begin{tabular}{lcrrr} 
Type & Projects & Number of Units & For Rent & For Sale \\
\hline Planned & 8 & 561 & 537 & 24 \\
Existing & 13 & 887 & 869 & 18 \\
Under Construction & 4 & 284 & 276 & 8 \\
Under Renovation & 3 & 140 & 140 & -- \\
Renovation Announced & 2 & 140 & 58 & -- \\
Total & 30 & 2,130 & 1,880 & 50 \\
Table 5: Downtown Tulsa Residential Housing in 2015. Source: Downtown Coordinating Council (2016)
\end{tabular}

For the past five years, Portland's Bureau of Planning and Sustainability (BPS) has been working on Central City (CC) 2035. CC 2035 would replace Portland's Central City Plan of 1988. In 2012, the Central City Concept Plan was published after two years of public involvement and citizen engagement. This established the direction in which the next three years would go; although the plan contained preferred designs, it was necessary to share these with residents in order to figure out what designs they wanted for their central city. The recommended draft for CC 2035 is expected to be published in August 2016 and will then be amended to Portland's 2035 Comprehensive Plan.

The CC 2035 process included planning projects for three areas of the central city: North/Northeast Quadrant Plan (2012), West Quadrant Plan (2015), and Southeast Quadrant Plan (2015). A separate group focused on wildlife and habitat restoration, as well as improved human access to the Willamette River; in 2014 the Central Reach Urban Design Concept was adopted to identify these opportunities. In order to increase transparency and increase citizen awareness, all of the documents related to the quadrant and central city plans can be accessed on the City of Portland's Planning and Sustainability website. 


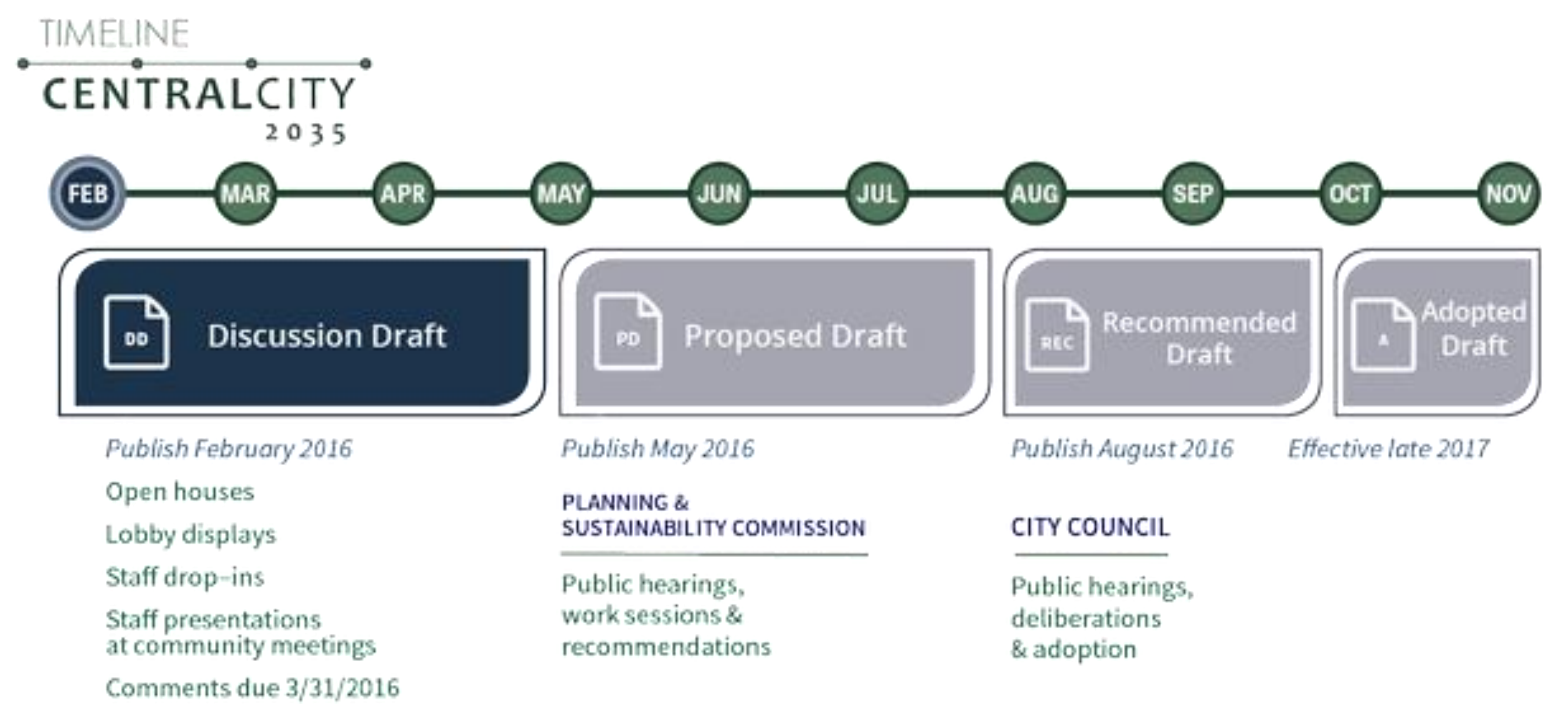

Image 17: Central City Plan's Timeline for Drafts. Source: Portland Bureau of Planning and Sustainability

A discussion draft of CC 2035 will be released spring 2016. Open houses, presentations at community meetings, and online access are some of the ways Portlanders will be able to learn more; citizens will have until March 31st to give comments. The Planning \& Sustainability Commission will work on a proposed draft which will be published in May, after public hearings and committee and community work sessions. A recommended draft will be presented to City council in the fall, at which time public hearings will be held to determine whether the plan is ready for official adoption. 


\section{TULSA PLANNING: 1980-2015}

This section provides a brief history of revitalization efforts in Downtown Tulsa from the 1980 District 1 Plan. A summary of the 2010 Tulsa Comprehensive is followed by an analysis of Tulsa Downtown Area Master Plan (2010).

The majority of Tulsa's historical planning documents were not available at the time of this writing. Tulsa City Library's Archives Department is in the process of digitizing their archives. The only historic planning document available is The District 1 Plan (1980). The plan provides historical information from 1950 to 1980 and lists the following planning documents as part of the historical framework of the planning process.

A Plan for Central Tulsa (1959) by Wise, Neutra, and Alexander

Planning Central Tulsa: A Blueprint for Action (1970) by Hammer, Green, and Siler

\section{District 1 Plan (1980)}

In 1980, Tulsa Metropolitan Area Planning Commission (TMAPC) partnered with Downtown Tulsa Unlimited (DTU) to create The District 1 Plan: A Plan for Downtown Tulsa. The 1980 District 1 Plan aimed to coordinate between public planning decisions and private development efforts; policies were not intended to control private development and instead served as a set of recommendations. See Appendix A for the Plan's study area maps.

The Plan contained fifteen pages of substantial background information on the history of Tulsa and the downtown area, as well as specific planning measures. Its section on the 1921 Race Riots was two sentences long and fails to emphasize the importance of this event on the evolution of downtown Tulsa.

The planning team consisted of downtown business and property owners, as well as residents and key players from the public sector; team members are not listed within the planning document (TMAPC 1980). Public opinion was gathered during a three-day workshop in the fall of 1979. Historical documents from the "Take part Workshop" were not available from Tulsa City Library archives at the time of this writing.

The District 1 Plan stressed that a "true partnership of the public and private sectors" was necessary for the plan to succeed. The plan was meant to guide future policy and planning decisions as well as advise private developers in downtown. The plan suggested new developments occur in the downtown area versus suburban areas and encouraged preservation of buildings and communities. Mixed-use projects, a more efficient transit system, and improved access to the Arkansas River were also elements of the 1980 plan. 


\section{Tulsa Comprehensive Plan (2010)}

The Tulsa Comprehensive Plan was adopted in 2010. Included in the Plan is Tulsa Vision, which serves as an executive summary. Tulsa Vision focuses more on the desires of Tulsans for their future city and serves as a guide for planning policies and projects, while the Comprehensive Plan outlines the strategies and plans necessary to meet those desires. The Comprehensive Plan covers five planning areas: land use; transportation; economic development; housing; and parks, trails, and open space. The City of Tulsa Planning Department states the Plan is not a regulatory document.

The purpose of the Plan is to "represent the persistent will and drive to reinvigorate downtown and the economy, to attract and retain young people and to provide them with opportunities to raise their families, and to connect our communities with diverse transportation options, through sound land use planning" (Tulsa Comprehensive Plan 2010). These are also referenced as the five key themes of the Plan.

During the planning process, six guiding principles were identified, which serve as the foundation for planning efforts to follow in order to stay true to the aspirations of Tulsans.

- Community and Housing: "Future development protects historic buildings, neighborhoods and resources while enhancing urban areas and creating new mixed-use centers."

- Transportation: "A variety of transportation options serve the city, so that all Tulsans can go where we need to go by driving if we want, but also by walking, biking or using public transit."

- Economy: "Downtown Tulsa should act as a thriving economic engine and cultural center for the entire region. Business owners are able to easily find adequate and attractive space for expanding business into downtown, along main streets, or in employment centers."

- Equity and Opportunity: "Tulsa is a cohesive city where we have the ability to create safe, healthy lives for ourselves and our families."

- Environment: "Tulsa becomes a leader in sustainability and efficiency. Residents have easy access to parks and natural areas."

- Planning Process: "City planning and decision-making is an inclusive and transparent process. Once adopted, city-wide and neighborhood plans are funded, implemented and monitored for performance. Development and zoning 


\section{DOWNTOWN REVITALIZED, COMMUNITY ORGANIZED}

policies are easily understood, workable and result in predictable development. Residents have a voice in solving their community's problems today and are part of planning for tomorrow."

Tulsa Vision presents six strategies to address guiding principles and key themes. The first four strategies have been addressed, to an extent. PLANiTULSA's role in connecting the fragmented City Planning office and creating demonstration projects is less clear.

1. Revise the city's zoning code. Tulsa's new zoning code became effective January 1,2016 . This is the first update to the city's Zoning Code in over 40 years. See Appendix A for Zoning and Land Use Maps for the Inner Dispersal Loop.

2. Create a redevelopment strategy that broadens housing options, creates new business spaces, and incorporates existing infrastructure.

3. Develop a new transportation strategy that improves network connectivity.

4. Strengthen neighborhood and small-area planning efforts.

5. Cooperate on developing PLANiTULSA's demonstration projects to highlight a variety of innovative building types.

6. Enhance coordination of long-range planning with current planning efforts, along with community and economic development, to move projects and initiatives forward.

Public involvement for Tulsa's Comprehensive Plan began in May 2009. More than 5,500 Tulsans attended workshops and responded to a city-wide survey on their opinions on four proposed scenarios for the future of Tulsa. "These scenarios were based on public workshops and other forms of input gathered during PLANiTULSA's process." The top two scenarios were a centralized city in Downtown and new centers throughout Tulsa. Support was strong for new possibilities instead of continuing the suburbanization trend present at the time.

"The vision is designed to reflect these diverse values and preferences, and accounts for the best aspects of the most popular scenarios: revitalizing downtown, reinvesting in Tulsa's corridors, preserving existing communities and building new neighborhoods and centers" (Tulsa Comprehensive Plan 2010).

In order to achieve the four proposed strategies, staff outreached to key stakeholders and conducted a public opinion survey. The survey included 1,000 interviews, stratified to US Census 2000 demographics, split across five geographical segments of city. Young people 
(ages 18-34) and residents with incomes under $\$ 25,000$ were two categories of respondents underrepresented by the survey. Top priorities identified by survey respondents included:

- Repairing and maintaining streets

- Improving public education

- New economic opportunities and jobs

- Clean air and water

- Improved public safety

- Health care

- Renewable energy sources

- Keeping young adults in Tulsa

- Support for small businesses and entrepreneurs

- Housing that is affordable

- Harmony among the races

These priorities are mirrored by common themes addressed by stakeholders. Tulsa is perceived as a friendly city that has a generous spirit but is also seen as intolerant, "old school" and resistant to change. Participants believe that inclusivity is a significant problem for the city and that Tulsa is fragmented along racial, class, and geographical lines. Tulsans desire a more sustainable city that moves away from automobiles as primary transit; however a strategy to do this is not clear. Finally, stakeholders voiced concern about implementation of city plans as they are envisioned; their concern is moving from idea to reality, and whether or not Tulsa is prepared with the funding and talent to accomplish the projects. 


\section{Tulsa Downtown Area Master Plan (2010)}

The Tulsa Downtown Area Master Plan (DAMP) was officially adopted in October, 2014 by the Tulsa Metropolitan Planning Commission and the City of Tulsa. DAMP is one of sixteen small areas and/or neighborhood revitalization plans; it was also the first plan to be amended as a component to Tulsa's Comprehensive Plan (2010). Information about DAMP, as well as the file, can be accessed via the City of Tulsa website.

The plan's mission or purpose is "to continue the established momentum by preparing a plan that connects Vision 2025 initiatives to existing and planned development and to recommend infill projects that leverage new public-private and private investment (DAMP 2010)".

The planning area was decided based on these same documents and includes areas surrounding the IDL which are essential for creating a more accessible downtown. The area within the IDL is zoned primarily as the Central Business District (CBD). Tulsa's 2016 Zoning Code defines the CBD under three primary intentions:

a. Accommodate and encourage the most desirable, most productive, most intense use of land, without regard to the regulation of building height, floor area, land coverage and parking requirements, within the central core area of the city. b. Encourage a diversity of high-intensity uses that mutually benefit from close proximity to, and from the available services of, the high transportation carrying capacity afforded by locations within the boundaries of the Inner Dispersal Loop. c. Preserve and promote the public and private investment of the existing central core area. 


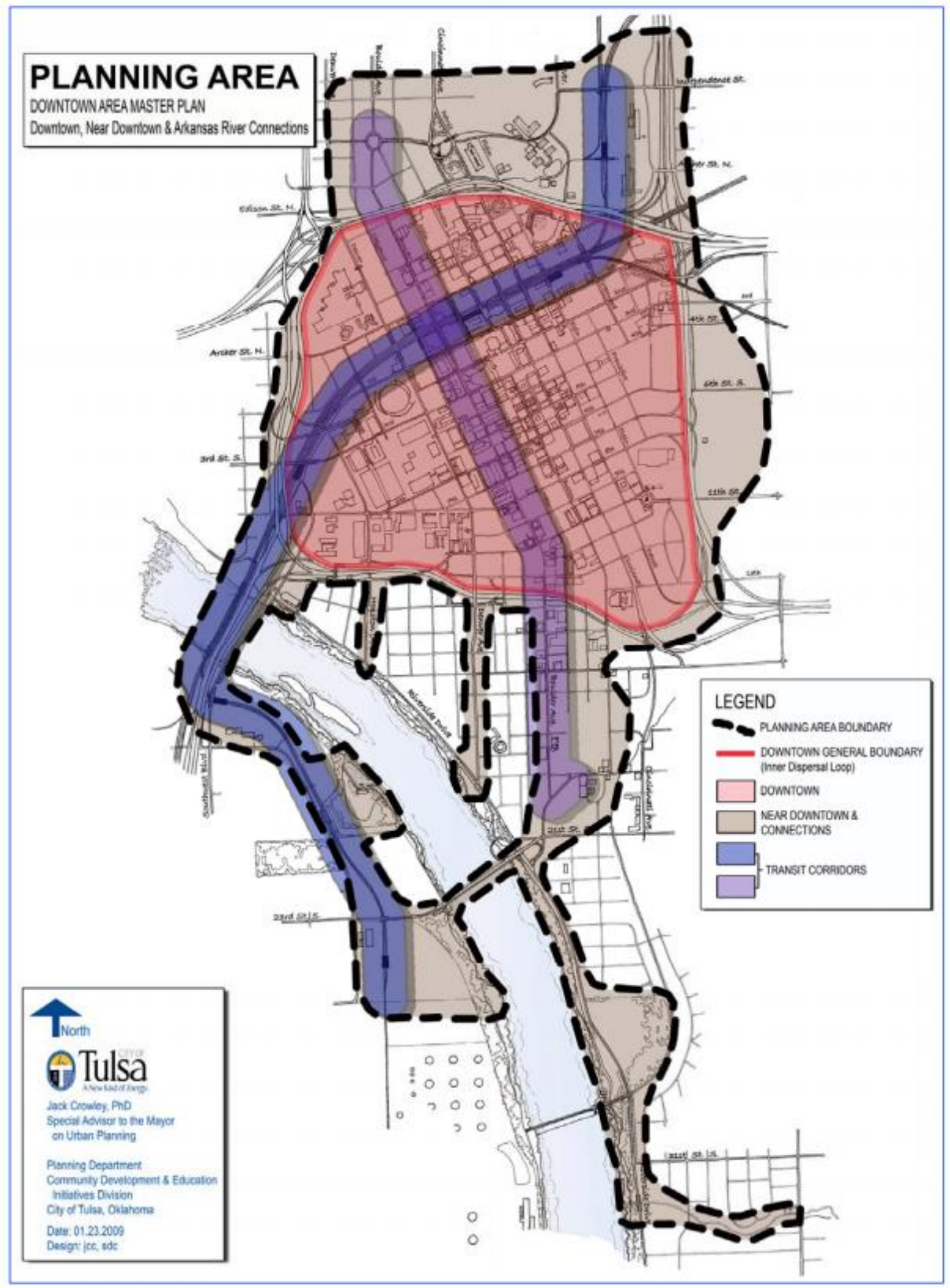

Image 18: Tulsa Downtown Area Master Plan Area. Source: City of Tulsa (2010) 
The plan centers around three goals: downtown revitalization, riverfront access, and rail transit. The first goal has dominated the last five years of planning efforts.

Revitalize the downtown area. In the past five years, the most effort has been towards downtown revitalization. Private development has led the effort, along with community organizers and Tulsa's citizens as a whole. Although the City of Tulsa's Planning Department has played a role, it is difficult to assess the extent of their impact on the changes which have occurred in the past five years. Updates to the Plan are not available on their website; the majority of news stories discuss private-public partnerships however there is little information on the level of authority the City of Tulsa has in these changes.

Connect downtown to the Arkansas River. Tulsa began riverfront development in 1974 with the creation of the Tulsa River Parks Authority. Trails and parks were created along both the east and west banks of the river. The first project to be completed was the Pedestrian Bridge, located at 29th St and Riverside Drive. This bridge is located roughly two miles south of the Inner Dispersal Loop (IDL) and is the closest pedestrian crossway between the east and west bank of the Arkansas River.

Tulsa's IDL halts pedestrian and public transit access to the Arkansas River. DAMP suggests policies which encourage connection with improved trails and pedestrian ways. The Arkansas Riverfront continues to be a priority for Tulsans

A new 100 acre waterfront park is currently under construction and aims to increase riverfront access while connecting disjointed areas along Riverside Drive. A Gathering Place for Tulsa, primarily funded by the George Kaiser Family Foundation, is scheduled to be completed in late 2017 and will mostly focus on development of the east side of the Arkansas River and will improve east-west pedestrian access. Their website includes information regarding donors, public participation, and concept plans.

Tulsans were invited to multiple public input sessions in 2012 prior to the groundbreaking in October 2014. Issues regarding pedestrian access along Riverside Drive have kept Tulsans involved in the planning process. In late 2014, Tulsa Mayor Dewey Bartlett decided to eliminate a sidewalk from the Plan, which would have connected the park to downtown. His decision sparked community frustration and organizing around the need for a pedestrian corridor. Citizens, including former mayors of Tulsa, as well as community organizations have rallied in order to encourage Mayor Bartlett to reconsider his position. Smart Growth Tulsa, a nonprofit which advocates for smarter public policies and inclusive healthy 
communities has been a key player in organizing Tulsans around this and other issues (Leighty 2014).

Initiate rail transit with downtown serving as the hub for city and regional travel. Although alternative transit and development of a regional rail line are emphasized for their importance by Tulsans and the Downtown Area Master Plan, this goal has seen the least amount of headway. Rail transit development was considered a high priority project, to be started within the first five years of the Plan. Potential funding sources may have shifted in focus since 2009 or other projects became higher priority for the city. Indian Nation Council of Government's initiatives to create a regional bus system could potentially serve as a better "first step" in regional transit than rail transit, which could cost upwards of one billion dollars (DAMP 2010).

Tulsa DAMP's planning process "engaged a broad spectrum of property owners, residents, citizens, merchants, community leaders, business associations, city-wide and regional organizations, and various other stakeholders". The two-year planning process aimed to be "extensive, transparent, broad based and participatory". Over 100 community groups were involved in the planning process and roughly 2,000 Tulsans participated in public meetings (Tulsa DAMP 2010).

The Downtown Tulsa Community Planning Process involved four steps. Examples of strategies and outreach among these four steps were not given in DAMP (2010).

1. Take stock: educate and understand

2. Dialogue: exchange Ideas and communicate

3. Envision the future

4. Implement initiatives and gain solutions 


\section{PORTLAND PLANNING: 1970-2015}

This section covers planning efforts which contributed or helped to shape current policy framework. An overview of Portland's rich history with citizen involvement, the 1972 Downtown Plan, and the 1988 Central City Plan are summarized. The chapter concludes with analysis of Portland's Central City Concept Plan (2012) within the context of the Portland 2035 Comprehensive Plan.

\section{0-70: Community Organizing and Participatory Planning in Portland}

Beginning in the mid-1960s, planners began to consider the "stopover neighborhoods" surrounding the central city which were often neglected for the planning of high density urban areas. This previous practice of neglect left many of Portland's oldest neighborhoods struggling for resources; these neighborhoods were often home to low-income immigrant or minority communities. Planners concentrated on the suburban areas and urban core and often believed that these stopover neighborhoods would naturally transition into areas which would support urban and suburban needs (Abbott 1983).

Many urban renewal projects were implemented within this area, including Portland State University's South Auditorium renewal project (Abbott 1983). These projects only further diminished the capacity of an already vulnerable community. Low quality apartments replaced single family homes in southeast until there was a more desirable use for the area. Throughout the 1950s and early 60s, Portland planners were simultaneously concerned about central city population loss while continuing planning practices that aimed to mimic the city's suburban rings. Neighborhood planning and civic engagement were not on the mind of planners at this point.

As more urban renewal projects were proposed for the city's "low-priority" neighborhoods, citizen unrest began to grow throughout the city. Residents throughout Portland would begin to organize around issues affecting their communities. For many residents of southeast Portland, the proposal of the Mt. Hood Freeway began their community organizing efforts. Although the project had been in the planning process for many years, community resistance began in the late 60 s when the city began to buy up property in southeast Portland for the eight lane highway (Leistner 2013).

Another issue which would mobilize Portlanders was Harbor Drive, which impeded access to the Willamette River. Portland's intentional decision to remove Harbor Drive in 1974 
and replace it with Tom McCall Waterfront Park four years later would signify that the human need for open space was of higher importance than the need for transit.

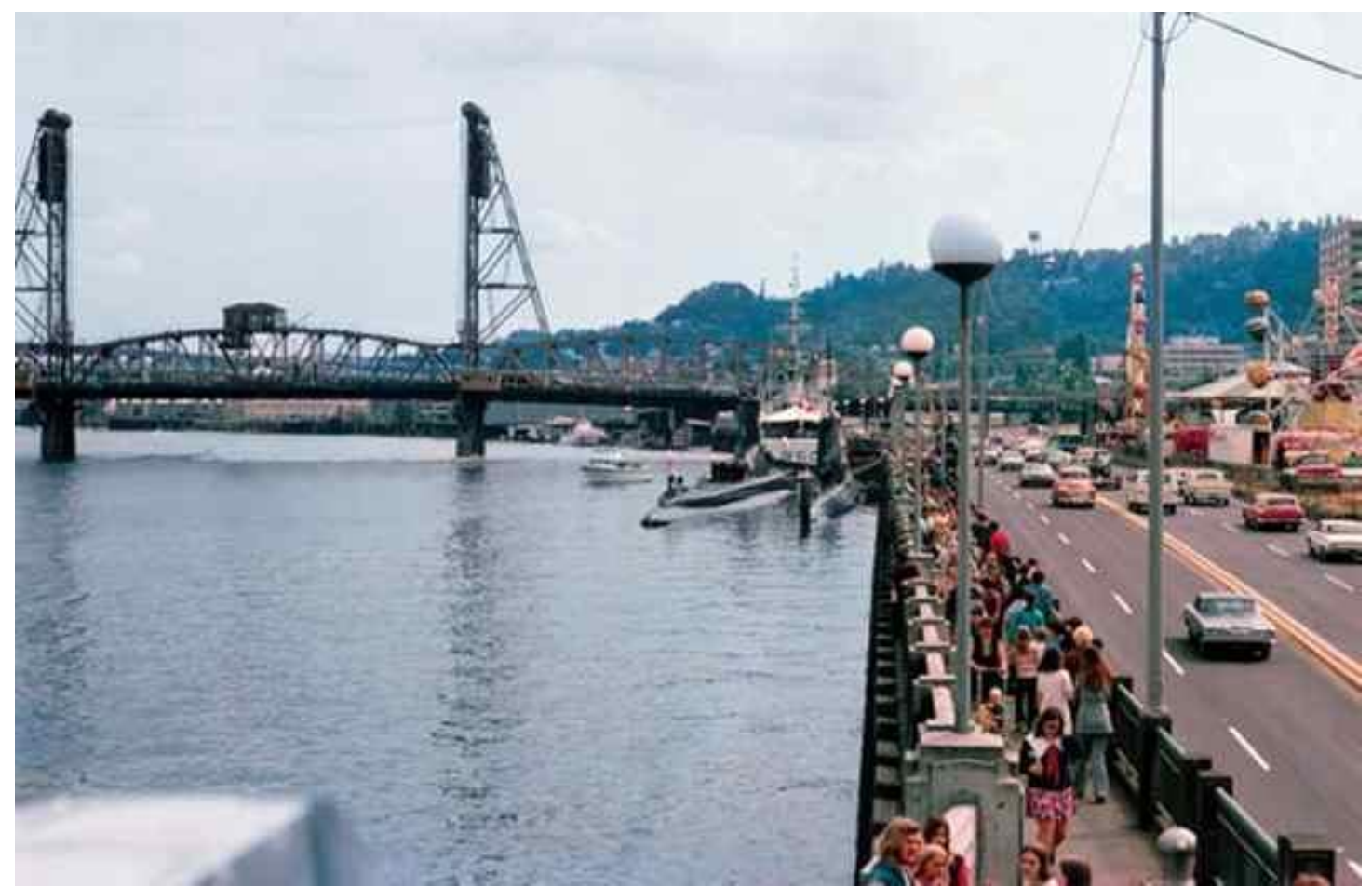

Image 19: Harbor Drive looking South toward Hawthorne Bridge, June 1971. Source: Thomas Robinson.

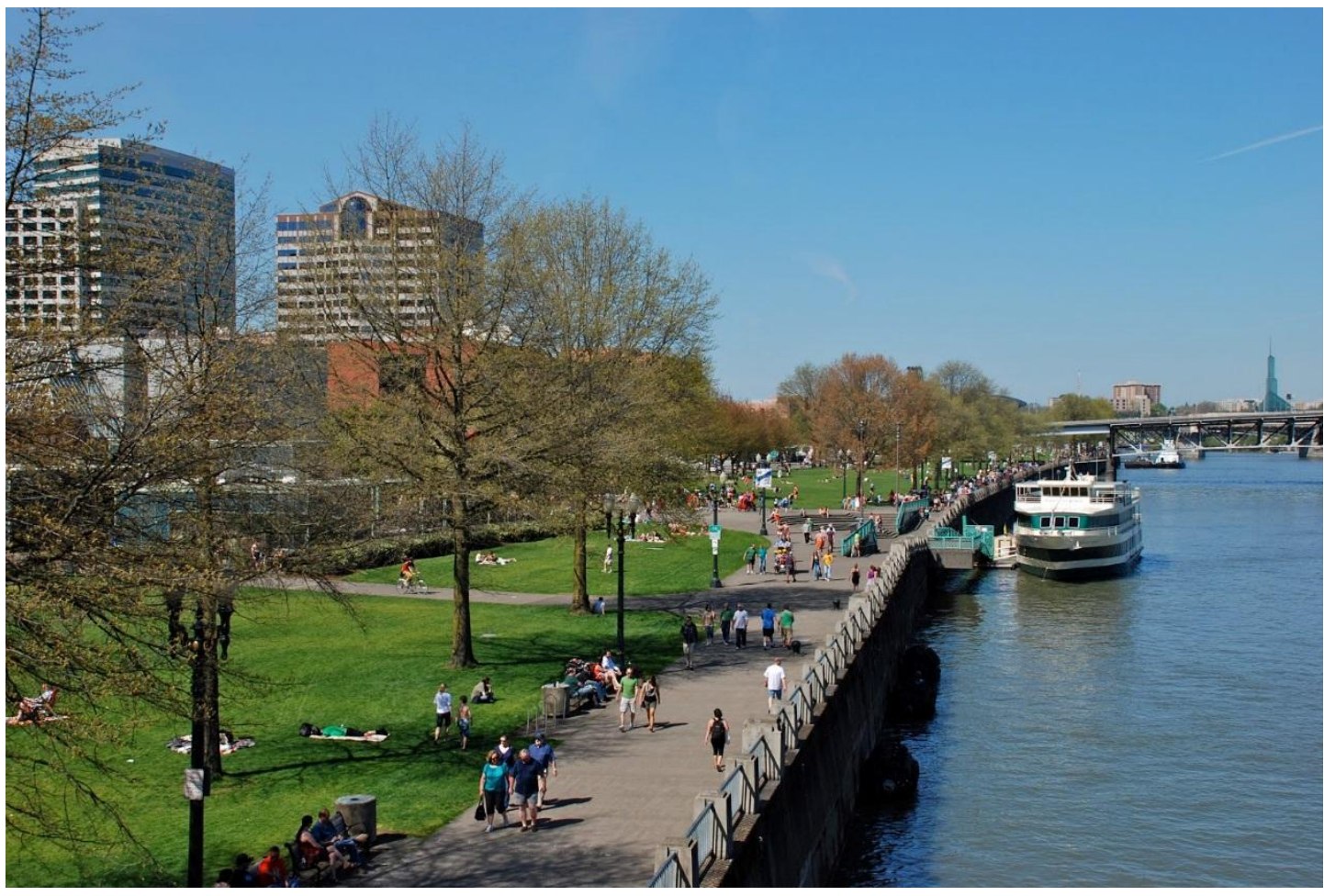

Image 20: Tom McCall Waterfront, facing North from Hawthorne Bridge, April 2012. Source: Steve Morgan. 


\section{DOWNTOWN REVITALIZED, COMMUNITY ORGANIZED}

Community organizers created a situation in which city officials were not able to move forward unless recognizing their power. City officials responded by welcoming organizers and establishing a more formal system for citizen action and engagement.

Mayor Neil Goldschmidt would emphasize this dynamic during his time in office (19731979). His central goal was to diversify Portland's neighborhoods and make them attractive to a variety of users and residents. He shifted transportation planning to public transit; this transition would help to connect residents of older neighborhoods to the greater city and economic opportunities Between 1974 and 1979, Portland's active neighborhood groups doubled to almost sixty groups citywide. (Leistner 2013).

Portland was adopting a more inclusive, grassroots, "bottom-up" planning process. An example of this is the Office of Neighborhood Involvement (ONI) which was established in 1974. City officials chose to strengthen the already present community organizations by giving them a valid place within city government. ONI's mission is to promote "a culture of civic engagement by connecting and supporting all Portlanders working together and with government to build inclusive, safe and livable neighborhoods and communities" (Leistner 2013).

ONI provides direct services that aim to increase neighborhood livability while overseeing the seven neighborhood districts that work with neighborhood associations. Crime prevention, information and referrals, and neighborhood involvement are among ONI's programs. The office can be seen as a switchboard: neighborhood organizations, community members, and city agencies are able to connect and communicate more efficiently because of this central entity.

The efforts of Portland's community organizers and city officials during the late 1960s and early 1970s continue to impact public policies and planning documents. Community members were now key players of planning the city. A model of participatory planning was embraced by the City of Portland in the 1972 Downtown Plan and continues to be an integral component for every planning document produced within the city. 


\section{Downtown Plan (1972)}

"The Downtown Plan [of 1972] is an opportunity for the citizens of Portland to say: let's first decide how we want to use our Downtown and then decide what tools are necessary to achieve our land use decision." -Dean Gisvold, Chairman of Citizens Advisory Committee

Portland's 1972 Downtown Plan was a collaboration between City Planning Commission staff and consultants, as well as the Citizens Advisory Committee. This committee would prepare a set of Citizen Goals to insure that any downtown policy or project reflected citizens' values and desires for their downtown. Citizens Advisory Committee stressed the importance of widely disturbing the Downtown Plan after its completion in order for the plan to be approved by the community-at-large, not just Portland City Council.

The Plan's Study Area included Downtown as well as multiple blocks north of Burnside Street, which serves as the demarcation between North and South sections of Portland. This section need to be included in order to complete the Portland Transit Mall and would signify the City's desire to plan for connectivity among districts of the central city. 


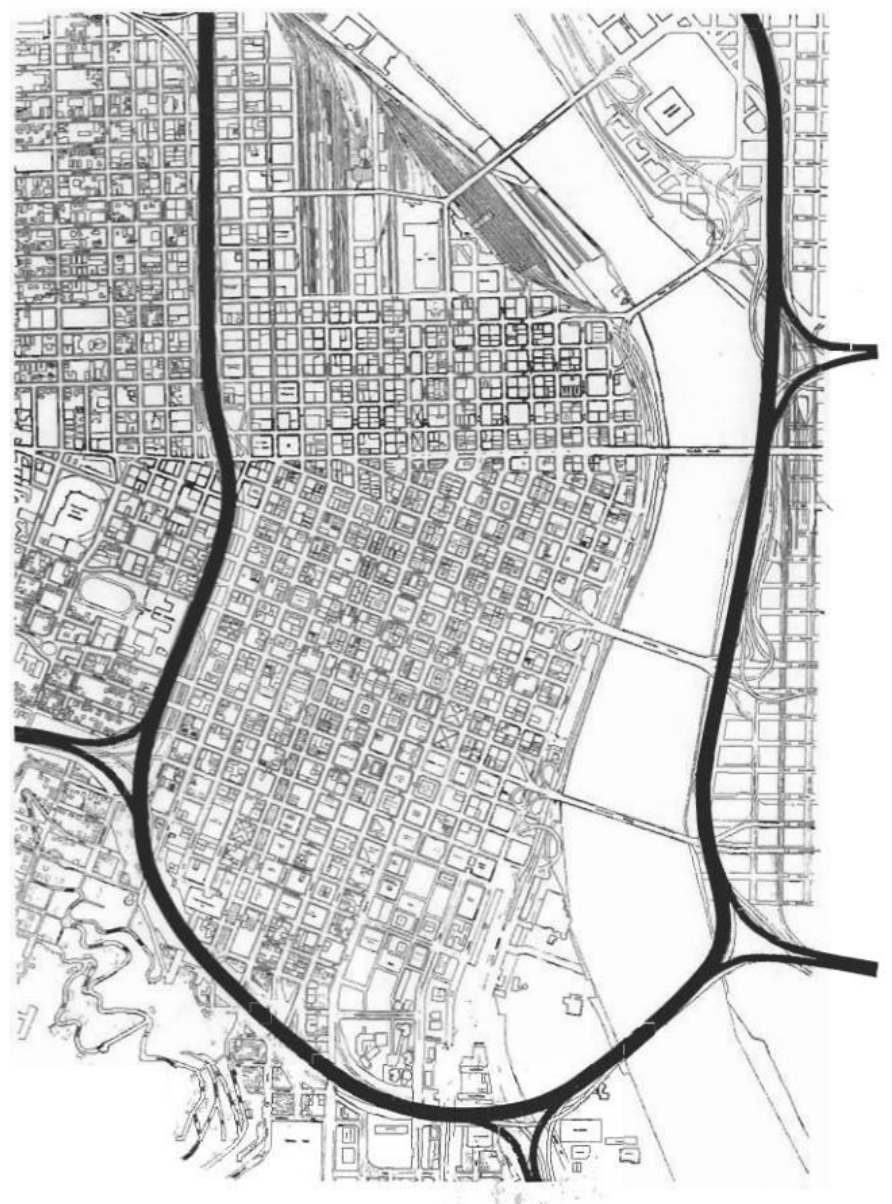

\section{STUDY AREA}

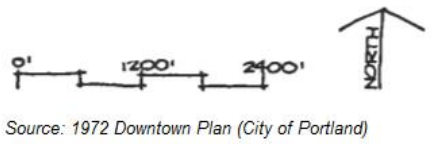

Image 21: Study area of Portland's 1972 Downtown Plan.

The 1972 Plan would lead to policies and projects that helped to define Downtown, and eventually the Central City, as the regional center. Not every goal would come to fruition; the following are examples of the largest successes from the plan:

- Created the framework for Portland Transit Mall, Metropolitan Area Express (MAX), and Central City Streetcar.

- Established a central retail core along transit mall with Pioneer Place as focus.

- Emphasized preservation of historic buildings and landmarks including Pioneer Courthouse, Multnomah County Library, City Hall, and Crystal Ballroom.

- Strengthened the Government Center as the voice for the city; led to construction of The Portland Building, Justice Center, and Federal Courthouse.

- Promoted a Cultural District along the northern edge of the South Park Blocks; the District includes Portland Art Museum, Oregon Historical Society, and Arlene Schnitzer Concert Hall. 
- Produced the Tom McCall Waterfront Park and Pioneer Square, two defining features of Portland.

\section{Comprehensive Plan (1980)}

In 1980 the Portland City Council adopted Portland's Comprehensive Plan, which provided coordinated decision-making guidelines for future growth and development of Portland. Comprehensive planning was to align with state-wide planning goals outlined by Oregon's Land Conservation and Development Commission (LCDC). Oregon's statewide land use planning program began in 1973. Of the 19 statewide planning goals, Citizen Involvement is listed first and is considered critical to the planning program. Goal 1 aims "to develop a Citizen Involvement program that insures the opportunity for citizens to be involved in all phases of the planning process" (Department of Land Conservation and Development 2010).

In 1976, the Portland Committee for Citizen Involvement (CCI) was formed in order to create procedures for citizen involvement during the comprehensive planning process. CCl's efforts would add two important citizen involvement elements into the planning process:

1. Each of the city's neighborhood associations were given the opportunity to record local issues and concerns to be addressed in the Comprehensive Plan;

2. Six months of citizen review are to be provided after completion of the first draft plan.

Portland's 1980 Comprehensive Plan created a city-wide vision for the next twenty year in Portland. The plan included: Comprehensive Plan map, development regulations, and a revised Zoning Code; Plan implementation, including a review and amendment process; and Land Use and Public Facilities goals to guide revitalization and development (Bureau of Planning, 1980).

\section{Central City Plan (1988)}

The 1988 Central City Plan replaced the 1972 Downtown Plan as the primary planning document for the heart of Portland. The 1988 Plan would attempt to clarify the role of Portland's Central City and review the successes and failures of the 1972 Downtown Plan. The Plan's objectives included the production of a plan compatible with the larger cities that established the relationship of the Central Cities district to each other and as a whole.

In 1984, Portland City Council appointed a 15 member Citizen Steering Committee to oversee public participation throughout the planning process. Almost 10,000 citizens of Portland 
would provide opinions and thoughts during the first phase of the planning process. These opinions ensured that the final Plan was representative of Portland as a whole.

In 1988, Portland's Central City was comprised of 2,750 acres of land; over half of the area's land use was commercial or industrial, with only 2 percent belonging to Open Space. Industry and Commerce continue to play an integral part in the Central City. Zoning designations varied throughout the Central City; this variation created distinctions among districts and allowed the Central City to develop a diversity of uses.

The Plan included citizen values and central city goals as well as functional policies in order to implement those goals. The Plan was updated after the City of Portland adopted a new Zoning Code for the city in 1991.

One of the most important effects of the Central City Plan was its emphasis on Willamette River as the center and focus of Portland. Efforts to increase access along both sides of the river and incorporate multiple recreational uses from the waterfront were strengthened by the Plan. Policies regarding Willamette River which would be echoed in future documents included:

- Enhance bridge walkways for pedestrians and bicyclists;

- Create riverfront loop that incorporates Eastbank Esplanade;

- Study the feasibility and location of a pedestrian and bicycle bridge;

- Enhance fish and wildlife habitat along the river. 


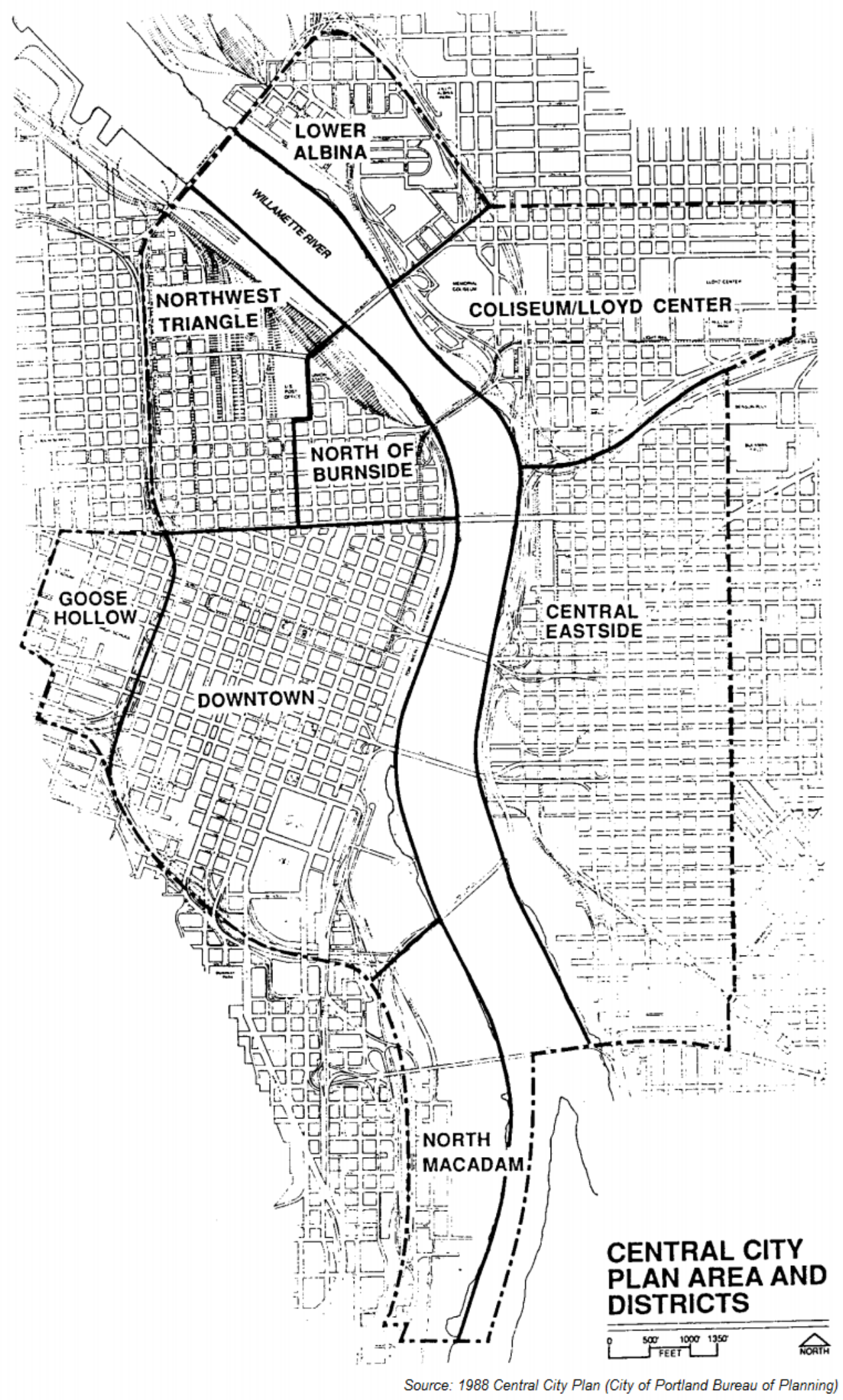

Image 22: Portland's Central City in 1988. 


\section{Portland Plan}

Portland City Council adopted the Portland Plan in April 2012 and will be incorporated into the upcoming update of Portland's Comprehensive Plan. The Plan involved more than 20 public agency partners along with thousands of Portland residents, businesses, and nonprofits. The Plan places equity at the center of the planning framework; this includes both long-range goals and short-term specific actions to made in order to achieve equity. Three strategies are presented which represent the major goals and strategies of the Plan. Twelve measures of success are outlined, with both long-range and specific outcomes (Portland Plan 2012).

\begin{tabular}{|c|c|c|}
\hline Framework for Equity & 3 Integrated Strategies & 12 Measures of Success \\
\hline $\begin{array}{l}\text { Close the gaps } \\
\text { Engage the community } \\
\text { Build partnerships } \\
\text { Launch a racial and } \\
\text { ethnic justice initiative } \\
\text { Increase focus on disability equity } \\
\text { Increase internal accountability }\end{array}$ & & $\begin{array}{l}\text { 1. Equity and inclusion } \\
\text { 2. Resident satisfaction } \\
\text { 3. Educated youth } \\
\text { 4. Prosperous households } \\
\text { 5. Growing businesses } \\
\text { 6. Job growth } \\
\text { 7. Transit and active transportation } \\
\text { 8. Reduced carbon emissions } \\
\text { 9. Complete neighborhoods } \\
\text { 10. Healthier people } \\
\text { 11. Safer city } \\
\text { 12. Healthy watersheds }\end{array}$ \\
\hline
\end{tabular}

Image 23: Strategies, Framework, and Measurements of Success from the 2012 Portland Plan.

3 Integrated Strategies were chosen for the Plan. Elements of the strategies include:

- Thriving Educated Youth: support for neighborhoods and communities that support youth with $21^{\text {st }}$ century challenges; shift from individual responsibility to community ownership of student success

- Economic Prosperity and Affordability: focus on growing employment districts and improving vitality of neighborhood businesses; education and job training; access to housing and improved economic security; public and private urban innovation

- Healthy Connected City: vibrant neighborhood centers that include greater connections to natural areas and other places in the city; focus on decisions which benefit the health and safety of residents. 
The Portland Plan includes a 5-Year Action Plan (2012-17) which outline specific steps partners will take to begin significant changes in the city. Actions vary from quick starts to longrange actions; emphasis is placed on actions that significantly reduce disparities and close the equity gap.

The Portland Plan differs from past plans in that the focus switched from land use to emphasizing the importance of people and their needs, both currently and in the future. Research showed that although Portland is becoming more racially diverse, access to resources and opportunities are not distributed equitably. The Plan also emphasizes that one size does not fit all - each neighborhood and district in Portland has a unique demographic and topographic makeup, which should be embraced by the Plan.

Public participation efforts for the Portland Plan included a variety of techniques from Fall 2009 until adoption of the Plan in April 2012. The Portland Plan's Participatory Planning and Public Involvement Process are extensively documented on the Portland Plan website. Summaries, progress reports, and participation videos are among the resources provided.

Phase 1 (Fall 2009 - Spring 2010) of public participation focused on the question "Where are we now?" This phase gathered information on current trends in Portland and aimed to increase participation throughout the city. 2,500 residents would participate in city-wide workshops and 13,000 Portland youth and adults completed Phase 1 Surveys. Nine action areas were set by staff based upon public input.

During Phase 2 (April-August, 2010), Portland residents weighed in on draft goals presented for the nine action areas and would try to answer the question "Where do we want to go?" Living wage jobs, quality education, and a healthy environment resulted as top priorities for Portlanders. Public participation and outreach approaches were designed to engage underrepresented communities. Phase II also target non-geographic communities: Seniors, faithbased communities, the business community, and the Lesbian, Gay, Bisexual, Transgender and Queer (LGBTQ) community were among these groups. Phase II would receive less participants (450 workshop participants and 6,500 survey respondents); these participants would more accurately represent the demographics of the city as a whole.

Phase 3 focused on strategy building and posed the question, "How do we get there?" In 2010, Portlanders had the opportunity to attend the Inspiring Communities Series, which highlighted best practices nationally and globally. Topics included education, equality, healthy and complete cities, environmental design, and economic development. These talks are available on the Portland Plan website, along with other videos from other summer events. Four 
Portland Plan Fairs were held which allowed for more interactive and fun ways to learn about the Plan.

Phase 4 occurred form June 2011 until April 2012. The final phase focused on the more formal process of public hearings, work sessions, and eventual City Council adoption.

\section{Central City (CC) Concept Plan}

"Portland's city center is an intentional place, crafted through a participatory process with the belief that planning, done publicly and acted on collectively, is a critical ingredient to success. The Central City is also a place of purposeful experimentation, a learning city where new ideas about reshaping the traditional urban landscape and civic involvement have been actively pursued."

Central City 2035 Plan (CC2035) Discussion Draft was released February 1, 2016. CC2035 is an updated version of the 2012 Central City Concept Plan, the document referenced and analyzed within this section. CC2035 will become the first amendment of Portland's newest update of their Comprehensive Plan; all phases of the planning process will incorporate planning and outreach strategies outlined in the Portland Plan (2012).

The CC Concept Plan begins by highlighting the accomplishments of the 1988 Central City Plan and 1972 Downtown Plan. This reflection on past accomplishments allows readers, whether they are government officials, planners, or residents, to recognize the effect Portland's participatory planning process can have. Central City 2035 aims to serve as a "long-range comprehensive planning and district planning effort" which embodies the four priorities of the Portland Plan: prosperity, health, equity, and education. These priorities can be seen in the plan's three themes:

1. "Equity is reflected in actions and decisions

2. Youth can thrive and emerge as future leaders

3. The heart of the city is prosperous, healthy and connected to the rest of the city and the region."

Six key ideas emerged during the CC Concept Plan process which would influence development of policies, goals, and implementation of CC2035. 
1. Civic and Cultural Center

Portland's City Center should aim to be more representative of the great variety of cultures present within the city; more art/cultural events should be affordable and reach a more diverse audience.

2. Focus on the Willamette River Opportunities for people to use and access the waterfront or be in the water should increase; the need for economic growth needs to be balanced with habitat and river restoration.

3. Innovation Quadrant Portland should capitalize on the density of educational institutions and businesses located in the Central City, build on these relationships, and coordinate development and investments that help everyone thrive.

4. Resilient Central City The Central City should aim to diversify employment and focus on housing affordability in order to insure diversity in residents; climate change mitigation and natural hazard preparedness will create greater resilience for the area.

5. Street Hierarchy and Development Character

Be more intentional with street uses in order to decrease traffic issues and preserve existing public views.

6. The "Green Loop"

Central City will include a six-mile path which will improve right-of-way for community use and connect Downtown's park system and the city's cultural and civic institutions to the rest of the city.

Urban design directions emerged from the $\mathrm{CC}$ Concept Plan and encouraged more connectivity and fluidity with the Central City. Design directions included: centralization of the Willamette River; establishment of a Southern and Northern "bookend"; emphasis on east-west orientation, with more orientation toward the Willamette; creation of a pedestrian/bicycle loop to complement the streetcar loop; and development of an Eastside center, including high-rise residential and more open space in the Lloyd District (Central City 2012). 


\section{DOWNTOWN REVITALIZED, COMMUNITY ORGANIZED}

The Central City Concept Plan includes four appendices: City Council Resolution; Public Involvement Process; Symposium Series Recommendations; and Background Reports and Studies. The intentional inclusion of these materials showcases the desire for a visible and honest planning process by project staff. These appendices allow reader to validate information presented in the 21 page document and learn more about the participation of citizens and stakeholders.

Appendix B of Central City Plan covers the public involvement process from June 2010 until July 2012. Within the first few sentences, the appendix lists the website for more current information on CC 2035. While not a mandatory component for planning documents, many of Portland's plans include information on how project staff outreached, who was involved in the process, and when/where the outreach happened. Project staff's enthusiasm to present this information within an appendix shows their commitment to create a participation process that is as inclusive and accessible as possible.

The following is a brief outline of public participation outlined in Appendix B:

- Project Website - lists every update to the site, as well as the variety of uses the website has. These include: planning documents; meeting agendas and minutes; project schedule; event calendar; and links to related information or other planning efforts.

- Mailing and Newsletters - monthly email announcements through an email list of $\sim 500$ interested parties. Articles were posted on the BPS website and distributed in the BPS bimonthly electronic newsletter, which were received by roughly 9,000 subscribers. The articles are cited.

- Media - Announcements for key planning events utilized local media to distribute information. These included the Oregonian, Daily Journal of Commerce, as well as neighborhood newsletters and other popular media outlets. A selection of six announcements are listed with their corresponding event. Summary of Events

- Meetings hosted by the CC 2035 teams - includes team type and date range

- Commission briefings - includes commission type and meeting dates

- Public events hosted by CC Team - Five events are listed, with their date and approximate attendance. The estimated attendance at CC 2035 Public Events totals 535 people. Demographics of attendants are not listed.

o Symposium Series (10/10-06/11) - 360 in attendance

o CC2035 \& N/NE Quadrant Open House (10/11) - 100 in attendance 
- Urban Design Workshop (11/10) - 35 in attendance

- Urban Design Workshop (04/11) - 20 in attendance

- Urban Design Workshop (06/11) - 20 in attendance

- Other meetings attended by CC 2035 team - 17 meetings are listed; these include neighborhood association meetings, Portland Business Alliance, Portland Plan Citizen Involvement Committee among others.

- Total attendance for all meetings and events is estimated at 3,775 people

Event Details are listed for CC 2035 Workshops, Symposium Series, Open House, Steering Committee Meetings, as well as the Advisory Group Meetings. Readers are able to learn meeting locations, times, participants, format used, and the intent of the event or meeting. For the Advisory Group and Steering Committee, all group members are listed with the business or group they represent. This information is incredibly helpful for the public to determine whether or not these groups represent their values and visions for the Central City. Often this information is difficult or even impossible to find, which can only increase distrust with citizens in the planning process.

The demographics of participants would be helpful, however this information tends to be difficult to acquire for privacy reasons. It is equally essential for participants to feel that their information is protected as well as project staff to outreach to historically under engaged or marginalized communities. 


\section{COMPARATIVE ANALYSIS}

This section summarizes analysis in the two previous sections and highlights key similarities and differences between the two cities. Analysis of downtown revitalization strategies and community engagement efforts outlined in the Literature Review follow. The final section suggests lessons Tulsa can learn from the past 45 years of efforts made in Portland.

\section{Similarities}

The 2010 Tulsa Downtown Area Master Plan (DAMP) and 2012 Portland Central City (CC) Concept Plan share similar themes throughout their respective plans. Some of these similarities include: relation to values of their Comprehensive Plan; emphasis on young people; and the strengthening of environmental and economic livelihood.

DAMP and CC echo the values of their cities' Comprehensive Plan. The Tulsa DAMP was created before the completion of Tulsa's Comprehensive Plan. This may result in slight differences between policy and planning goals. The Tulsa Comprehensive Plan places a strong emphasis on downtown revitalization and development so this is unlikely. Portland's Central City 2035 Plan and the Portland Plan have also been on similar planning timelines. Multiple drafts and public involvement phases solidify Portland Plan's impact on the Central City Planning process.

Both plans emphasize the importance of young people for the future of their cities. One of the main themes of Tulsa DAMP is the creation of a "24/7" downtown in order to attract younger Tulsans to live, work, and play in the area. Their efforts are working, albeit slowly. An increase in affordable housing options and general goods and services will help the area seem more livable. The next step is to improve educational opportunities of youth, which is the focus of Portland's CC Concept Plan.

Environmental health is an essential component in the plans. Both cities value the positive impacts of environmentally sustainable practices and suggest future development keep this in mind. Open spaces and better connections to nearby natural resources, such as their respective rivers, are top priorities for the cities. 


\section{DOWNTOWN REVITALIZED, COMMUNITY ORGANIZED}

Tulsa's Downtown and Portland's CC will continue to be the economic center for the city. Both cities aim to diversify the types and sizes of businesses and industries located in their downtown or central city. Tulsa's efforts are more focused on development of new business that will create a "24/7" downtown, as DAMP identified that the area already had strong pre-existing "9-5" office based business. Portland is also focused on diversification, as well as strengthening the Central City as a regional and national economic center.

Tulsa and Portland have waterfronts which serve as invaluable resources for the city. Although the circumstances may differ, Tulsa's recent community organizing around sidewalk development is similar in energy to Portland in the late 1960s, which led to the development of Tom McCall Waterfront Park. Both situations involved a variety of players including citizens, community organizations, and public agencies such as neighborhood associations and advisory boards. Community organizers were arguing for priority to be given to human need instead of vehicle use. In Portland, city planners and officials saw the benefit of welcoming organizers to the table and integrating their knowledge base into policies and plans.

Portland's organizing efforts can serve as an example to Tulsa's city officials and planners in the importance of collaborating with citizens on issues they find important. Although construction has begun on Tulsa's waterfront park, A Gathering Place, there is still time for city officials to choose a more collaborative decision-making process.

\section{Differences}

The primary way in which Portland and Tulsa's Plans differ is in their approaches towards public involvement throughout the process. Tulsa has put in great effort to crafting a Tulsa Comprehensive Plan (2010) which represents its citizens; these efforts are mirrored in the Neighborhood Small Area Plans including the Downtown Area Master Plan (DAMP). Where the cities differ is that Portland includes more public participation avenues for its citizens after the creation of the plan. The fact that citizen input is requested in between plan drafts may extend the timeline for adoption and implementation but it also creates a document which has been vetted multiple times by citizens.

Tulsa's amount of time for engagement in the planning process is adequate but could be better. Portland Central City (CC) Concept Plan began its outreach process in 2010. Four phases of outreach led to the final version of the discussion draft. Two more drafts (proposed 
and recommended) will come before the adopted draft in late 2017. All of the information a citizen would need to stay informed is on the City of Portland Bureau of Planning \& Sustainability website, including relevant historical documents. The variety and multitude of engagement opportunities has led to a product that more accurately represents the current views of Portlanders. Transparency within documents also contributes to a heightened sense of trust between citizens and city government.

Tulsa has little to no connection to past historical planning documents. Both the Tulsa Comprehensive Plan (2010) and Downtown Area Master Plan (2010) quickly reference the existence of said documents; however their absence speaks strongly to the city's lack of transparency. Information regarding historical planning documents is even more essential as none of these documents are readily available online.

One reason for this might be the lack of urban studies scholars in the city. Carl Abbott, professor emeritus at Portland State University, has been instrumental in researching and documenting the history of planning in Portland. Universities such as University of Tulsa should consider the research opportunity available to both professors and students in digitizing and analyzing historical planning documents and historical materials in general.

The Central City is much more pedestrian and bicycle friendly than Tulsa's downtown. Throughout the revitalization process, city leaders should advocate for projects which increase the walkability of downtown; one of the reasons Portland has a higher bike score is due to bicycle lanes and rights-of-way at intersections. For both cities, their downtowns are much more walkable than the metropolitan area and are surrounded by some of the city's most pedestrian friendly neighborhoods. As Tulsa improves in the connectivity between downtown and surrounding neighborhoods, it is likely that the downtown area will become even more walkable.

\begin{tabular}{lcll} 
& Walk & Transit & Bike \\
Tulsa & 36 & 23 & 44 \\
Downtown & 78 & 48 & 56 \\
Portland & 63 & 51 & 72 \\
Downtown & 99 & 94 & 98 \\
Central Eastside & 92 & 73 & 100 \\
\multicolumn{2}{c}{ Table 6: 2016 } & Walkability Scores for Tulsa and Portland. \\
\multicolumn{4}{c}{ Source: Walkscore.com }
\end{tabular}




\section{SUGGESTIONS FROM PORTLAND TO TULSA}

Establish human needs as the primary use of space. Pioneer Courthouse Square and Tom McCall Waterfront both address the need for open spaces for recreation and gathering within the city. Guthrie Green is an example in Tulsa and projects like this should be continued throughout the downtown area, especially in areas that could help bridge the gap between Downtown and the Arkansas River.

Create an official public participation process or policy for the city. Oregon Laws 197.160 and 197.165 establish advisory committees at a state and local level that assure planning processes incorporate widespread citizen involvement throughout the process. Laws like these establish trust and are a tool for creating equity among citizens.

Strengthen the role of neighborhood associations with the planning process with a focus on establishing equity among the city's neighborhoods. The Office of Neighborhood Involvement (ONI) was a result of the amazing community organizing efforts of the late 1950s and 1960s. As Tulsans mobilize around neighborhood and city-wide issues, the City of Tulsa should be prepared with structures to equalize power and invite a more diverse range of decision-makers to the table. Tulsa's Working in Neighborhoods (WIN) Department has the potential to serve as this entity, especially the extension program Neighborhood Liaisons.

Strengthen the connection between east and west Tulsa. As Portland moved away from planning just for Downtown and focused on the Central City, greater connections were created from the parts of the city which were separated by the Willamette River. The majority of planning efforts and community focus is applied to parts of Tulsa which are east of the Arkansas River. As Tulsa begins to plan for areas outside of the Inner Dispersal Loop (IDL), emphasis should be placed on incorporating the neighborhoods and areas on the west side of the river so that these citizens can also reap the rewards of a thriving central city.

Consider the spillover effects of downtown revitalization. The neighborhoods surrounding the IDL are ripe for new growth and development. The City of Tulsa should use caution when developing these areas. Working class neighborhoods west and north of the IDL are incredibly vulnerable to displacement as a result of gentrification. Planning efforts in North Tulsa should be extremely empathic of the disinvestment and neglect many residents have had to face as a result of the 1921 Race Riots. Participatory planning and increased community engagement efforts are essential in order to honor and uplift these neighborhoods. With the 
centennial anniversary quickly approaching, Tulsans throughout the city need to begin considering what this scar on the city means to them and how they can help to move race relations forward in a harmonious and respectful manner.

Continue efforts to link the Tulsa metropolitan region via a robust public transit network. Tulsans dream of a regional light-rail transit network, however these plans tend to be costly and can take decades to be completed. Efforts should continue to focus on the creation of a regional bus system and pedestrian/bicycle rights-of-way and trails. Once these foundations are streamlined and Tulsans are no longer dependent on their cars for travel, more options such as light-rail should be explored.

Continue to improve the power balance between public agencies, private entities, nonprofit or third party sector, and the general public. Tulsans from every background are coming forward to improve their city and downtown. The City of Tulsa's Planning Department should serve as the main organization in charge of revitalization efforts and create a platform for dialogue between the many groups involved in these efforts. It should also evaluate the power dynamic and create policies which assure a balance between private, public, and non-profit sectors.

Aim for transparency in the planning process. The City of Tulsa has made strides to include more Tulsans in initial planning processes but efforts made after plan completion for ongoing engagement are less clear. Citizens are not likely to learn about engagement opportunities from the City of Tulsa's website. This site is a key tool for city-wide engagement and should be utilized to its full extent. Creation of a user-friendly citizen involvement site would allow for more Tulsans to get and stay informed about what's happening in their city. Tulsa should also be more transparent about who is getting involved; advisory committees and key stakeholders that influence planning decisions are often not identified. Tulsans should have access to this information and be able to decide whether they represent the city as a whole.

Increase availability of planning documents. Tulsa's current planning documents are available online; appendices covering participation and initial research are also available. The City of Tulsa's Planning Department should concentrate on making historical planning documents available to both the general public and academic researchers. Planners should evaluate these past planning documents in order to better contextualize current revitalization efforts in the downtown area. 


\section{CONCLUSION}

So after five years, how much progress has Downtown Tulsa actually made?

Tulsa is making a great amount of progress in revitalizing their downtown. Projects such as Guthrie Green, ONEOk Field, and the FAST Forward Outreach Bus prove that public agencies are involved in the planning process, albeit less visible than other initiatives by the private and non-profit sector. Increased housing options and a vibrant local business community have brought more Tulsans downtown to work, play, or live. A diverse collection of non-profits, such as Tulsa Young Professionals, Downtown Tulsa Unlimited, and John Hope Franklin Center for Reconciliation, are helping to bring more Tulsans into the discussion of what their downtown should look like.

As Tulsa moves forward, city leaders and planners should continue to engage Tulsans in the planning process. The most important next step will be to create a more dynamic and robust engagement program. Portland has been able to reach a mature phase in the planning process and ask more critical questions regarding equity and inclusion throughout the city. A streamlined system takes time: Tulsa should be prepared for this. Forty years from now, analysis of Tulsa's revitalization process will hopefully not focus on projects, but on the immense progress Tulsa's citizens and city leaders have made on becoming more connected and engaged with one another.

Further research should focus on Tulsa's historic planning documents; these documents need to be gathered, digitized, and evaluated in order to better understand their impact on current trends and plans in the city. Another research opportunity is evaluation of the first five years of Tulsa's Downtown Area Master Plan. This research could involve Tulsans and help show what strategies are proving most effective in revitalizing downtown. This evaluation should continue throughout the thirty year timeline of the Plan.

This paper contextualizes the two cities in a qualitative manner. Quantitative research would strengthen the findings presented, as well as more depth of research presented. Multiple revitalization strategies are not presented, and individual engagement techniques are not examined. These two types of research strategies would lead to a better understanding of how Tulsa and Portland are similar and opposing in their efforts to revitalize their cities, and whether these efforts accurately represent the views of their citizens. 


\section{DOWNTOWN REVITALIZED, COMMUNITY ORGANIZED}

\section{WORKS CITED}

Abbott, C. (1983). Portland: Planning, Politics and Growth in a Twentieth Century City. Lincoln, Nebraska: University of Nebraska Press.

Abbott, C. (1991). A History of Metro. Retrieved from http://www.oregonmetro.gov/sites/default/files/abbott-a_history_of_metro_may_1991.pdf

Abbott, C. (1997). Portland: Gateway to the Northwest. Tarzana, CA: American Historical Press.

Ambler, C. (2009). Downtown Tulsa Intensive-Level Historic Resources Survey. City of Tulsa.

Arnstein, S. R. (1969). A ladder of citizen participation. Journal of the American Institute of planners, 35(4), 216-224.

Bluestone, B. (1983). Deindustrialization and unemployment in America. The Review of Black Political Economy 12.3: 27-42.

Boatman, J. (1967). Urban Renewal. Obtained from Tulsa City-County Library Archives Department.

Brambilla, R., \& Longo, G. (1977). For pedestrians only: planning, design, and management of traffic-free zones. Watson-Guptill.

Brewster, M., Hurtado, D., Olson, S., \& Yen, J. (2009). Walkscore. com: A new methodology to explore associations between neighborhood resources, race, and health. Retrieved Electronically From: https://apha. Confex. com/recording/apha/137am/pdf/free/4db77adf5df9fff0d3caf5cafe28f496/paper205082_1. pdf.

City of Portland. (2012). The Portland Plan.

City of Portland. (1972). 1972 Downtown Plan Planning Guidelines.

City of Portland Bureau of Planning. (1980). Comprehensive Plan Goals and Policies.

City of Portland Bureau of Planning. (1988). Central City Plan. 


\section{DOWNTOWN REVITALIZED, COMMUNITY ORGANIZED}

City of Portland Bureau of Planning. (2005). Historical Landmarks in Portland's Downtown Plan.

City of Portland Bureau of Planning and Sustainability. (2012). Central City 2035 Concept Plan.

City of Portland Bureau of Transportation. (n.d). Parking. Retrieved from https://www.portlandoregon.gov/transportation/34782

City of Tulsa. (2010). Tulsa Comprehensive Plan.

City of Tulsa. (2010). Downtown Area Master Plan.

Community Planning Toolkit. (n.d). Community Engagement. Retrieved from http://www.communityplanningtoolkit.org/community-engagement

Community Tool Box. (n.d). Tools to Change our world. Retrieved from http://ctb.ku.edu/en

Cortright, J. (2009). Walking the walk: How walkability raises home values in US cities. Retrieved from http://www.reconnectingamerica.org/assets/Uploads/2009WalkingTheWalkCEOsforCities.pdf

Department of Land Conservation and Development. (2010). Oregon's Statewide Planning Goals \& Guidelines. State of Oregon.

Downtown Coordinating Council. (2016). Investment and Reports. Retrieved from http://downtowntulsaok.com/pages/about/planned-investment-reports/

Dye, R. F., \& Merriman, D. F. (2000). The effects of tax increment financing on economic development. Journal of Urban Economics, 47(2), 306-328.

Ellsworth, S. (2001). The Tulsa Race Riot. Tulsa Race Riot: Report, gathered by the Oklahoma Commission to Study the Tulsa Race Riot of, 1921, 21-35.

England, T. (1971). Tulsa Model Cities. Tulsa, OK: Tulsa Model Cities Program.

Everett, D. (n.d). Indian Territory. In Encyclopedia of Oklahoma History and Culture. Retrieved from http://www.okhistory.org/publications/enc/entry.php?entryname=INDIAN\%20TERRITORY 


\section{DOWNTOWN REVITALIZED, COMMUNITY ORGANIZED}

Faulk, D. (2006). The process and practice of downtown revitalization. Review of Policy Research, 23(2), 625-645.

Gregory, C. (n.d). Tulsa. In Encyclopedia of Oklahoma History and Culture. Retrieved from http://www.okhistory.org/publications/enc/entry.php?entry=TU003

Indian Nation Council of Governments. (n.d) INCOG News and Updates. Retrieved from http://incog.org/Headlines/headline_3-14-11.html

Johnson, T., \& Tashman, J. (2002). Urban renewal in Oregon. Tashman Johnson LLC.

Johnson, S. R. (2002). The transformation of civic institutions and practices in Portland, Oregon, 19601999. Diss. Portland State University.

LaFortune, R. (1974). Tulsa 1975. Metropolitan Tulsa Chamber of Commerce.

Leighty, B. (2014). Two Steps to Save the Riverside Drive Sidewalk. Retrieved from http://smartgrowthtulsa.com/two-steps-to-save-the-riverside-drive-sidewalk

Leinberger, C. B. (2005). Turning around downtown: Twelve steps to revitalization. Brookings Institution Center on Urban and Metropolitan Policy.

Leistner, P. R. (2013). The Dynamics of Creating Strong Democracy in Portland, Oregon-1974 to 2013. Diss. Portland State University.

Mason, R. (2005). Economics and historic preservation. Washington, DC: The Brookings Institution.

Merrick, M., Tremoulet, A., \& Dippert, T. (2015). Promising Practices for Long-Term Community Engagement. Institute of Portland Metropolitan Studies.

Robertson, K. A. (1995). Downtown redevelopment strategies in the United States: An end-of-the-century assessment. Journal of the American Planning Association, 61(4), 429-437.

Rypkema, D. D. (1991). The economics of rehabilitation. National Trust for Historic Preservation. 


\section{DOWNTOWN REVITALIZED, COMMUNITY ORGANIZED}

Schriver, Judy. (n.d). Business Relocation and Downtown Tulsa Renewal. Obtained through Tulsa CityCounty Library Archives Department.

Tulsa Metropolitan Area Planning Commission. (1980). The District 1 Plan: A Plan for Downtown Tulsa. Obtained through Tulsa City-County Library Archives Department.

Tulsa Transit. (n.d). MTTA History. Retrieved from http:/tulsatransit.org/useful-info/mtta-history/

TriMet. (2015). Making History: 45 Years of TriMet and Transit in the Portland Region. Portland: TriMet.

United States Census. (2016). Frequently Asked Questions. Retrieved from https://ask.census.gov/faq.php?id=5000\&faqld=6669

Vincent, S. (2014, May 5). Street CReD events draws 2,500 to downtown Tulsa. Tulsa World. Retrieved from http://www.tulsaworld.com/news/downtown/street-cred-event-draws-to-downtowntulsa/article_0f446f78-2616-5a93-9527-ac23cabe34df.html

Von Hoffman, A. (2000). A study in contradictions: The origins and legacy of the Housing Act of 1949. Housing policy debate, 11(2), 299-326.

Weber, R. (2013). Tax increment financing in theory and practice. Financing economic development in the 21 st century, 53,55 . 
DOWNTOWN REVITALIZED, COMMUNITY ORGANIZED

\section{APPENDIX A: PORTLAND PLANNING TIMELINE}

1957 South Auditorium Urban Renewal Project begins

Fair Housing Act adopted by Oregon Legislature

1958 Portland Development Commission (PDC) established

Morrison Bridge opens

1959 Portland Zoning Code adopted

1960 Comprehensive Freeway System Plan adopted (never fully funded or executed)

Veterans Memorial Colosseum opens in Lloyd District

1964 Minnesota Freeway (Interstate 5) opens

1966 Marquam Bridge opens

1967 Model Cities Program established

1968 Downtown Waterfront Plan recommends elimination of Harbor Drive

1969 Creation of TriMet replaces local bus lines with region-wide system

Portland citizens vote to remove Harbor Drive and replace with waterfront park

1971 Powell's Books, the largest independent bookstore in U.S., opens on Burnside St.

1972 Portland Downtown Plan adopted by City Council

1973 Neil Goldschmidt elected mayor of Portland (1973-1979)

Bureau of Planning created after reorganization of the Planning Commission

Oregon becomes first state to adopt a Comprehensive Plan

Fremont Bridge completed

1974 Office of Neighborhood Involvement (ONI) created

Former site of the Portland Hotel chosen as a downtown gathering place

Oregon Health \& Science University established

Portland Saturday Market founded

1976 Portland Committee for Citizen Involvement (CCl) formed

Mt. Hood Freeway Project officially cancelled

1978 Portland Transit Mall opens

Metropolitan Area Express (MAX) development and construction begins

Tom McCall Waterfront opens

1979 Metro (Metropolitan Service District) formed as regional government

Urban Growth Boundary established 
1980 Portland Comprehensive Plan adopted by City Council

1983 Pioneer Courthouse Square completed

1984 City Council appoints Citizens Steering Committee to oversee public participation efforts for upcoming Central City Plan

1985 Iconic Portlandia statue erected in downtown

1986 MAX Blue Line from Gresham to Portland opens

1988 Central City Plan approved by City Council

Two waterfront festivals, Oregon Brewers Festival and Blues Festival, begin

1990 Bicycle Transportation organized

1991 Zoning Code update adopted by City Council

1992 Portland's first Farmers Market hosted on Park Blocks at Portland State University

1994 Portland Streetcar planning approved by City Council

1995 Rose Garden Arena opens in Lloyd Center

2001 Portland Streetcar began operating from Portland State University to NW Portland Eastbank Esplanade opened

2004 Rose Garden Arena files for bankruptcy

2006 Portland Aerial Tram opens and connects OHSU campus to South Waterfront. 


\section{APPENDIX B: PHOTO TOUR OF DOWNTOWN TULSA}

Date: $12 / 18 / 15$

Neighborhoods: Brady Arts District, Greenwood Historical District, East Village.

All photos were taken by author.

I started my walk at E 2nd Street and S Boulder Ave - right on the edge of Deco District, which can be considered the economic center of downtown. I ended my tour at E 7th St and S Kenosha Ave in East Village. The map to the right depicts the route taken. The majority of the buildings which make up Downtown Tulsa's iconic skyline are located in the Deco District. When Tulsans visit Downtown, it's often in the Deco and the Blue Dome District. The train tracks serve as a physical barrier between North and South Downtown. North Downtown was known for its commercial and industrial businesses, the connection to Tulsa Race Riots along Greenwood Avenue, and $10-15$ years ago was considered unsafe and to be avoided.

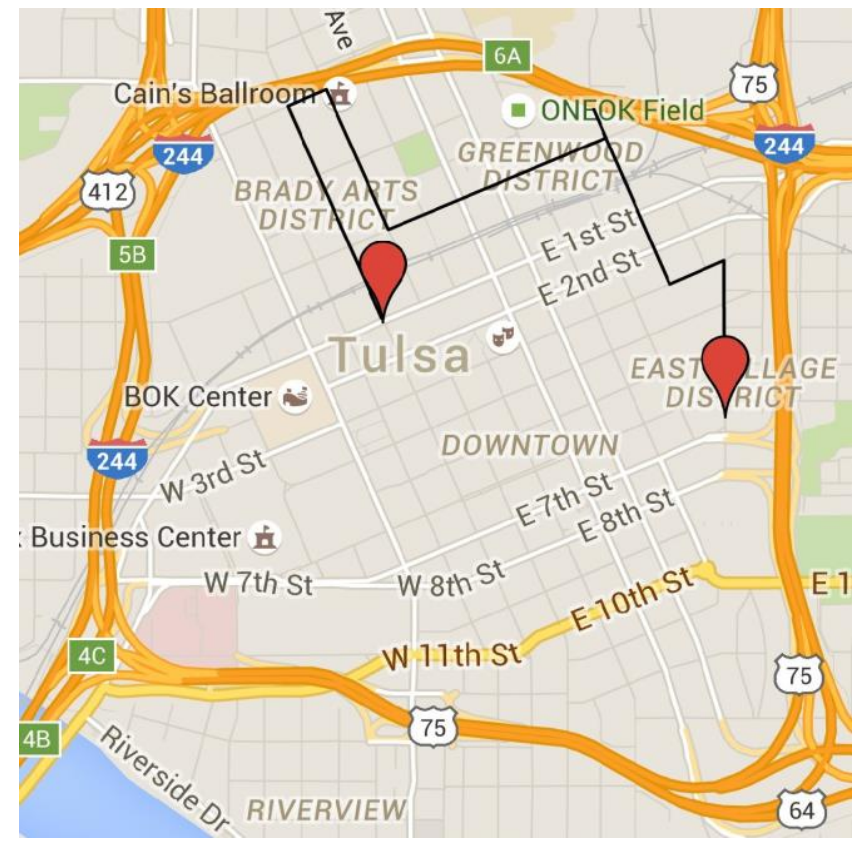

That perception has changed though, and now Brady Arts District is receiving the majority of development projects, including housing. These photos serve to contextualize the shift in Tulsa planning which can still be observed today. 


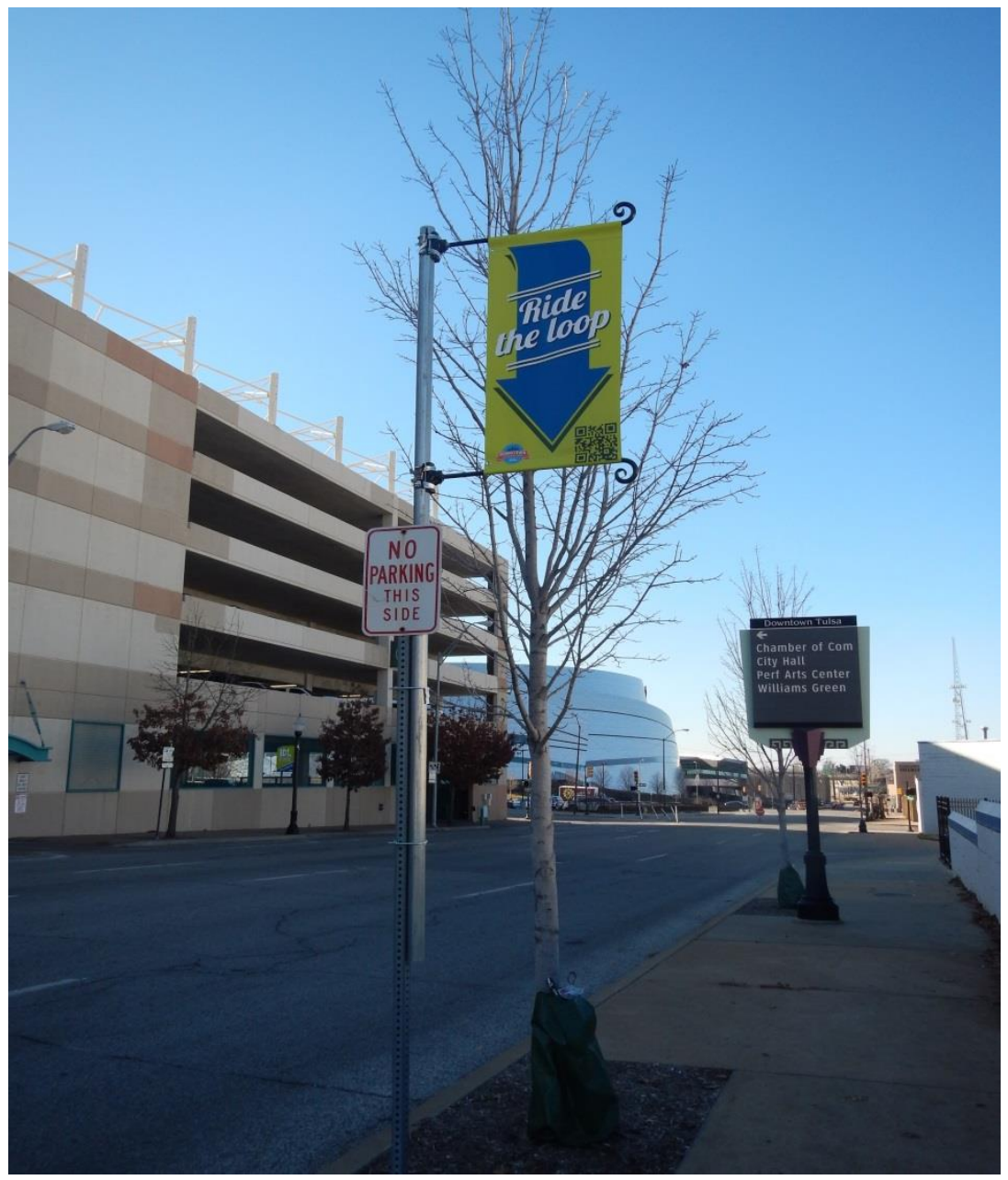

Maps and signage were observed before crossing over the railroad tracks. " in the loop" is the City of Tulsa's new campaign for the Inner Dispersal Loop (IDL). The difficulty in this campaign is that it is not currently possible to navigate through the IDL on public transit.

In the background are directional signs for important civic buildings. These signs are most common in the Deco District, where the majority of government buildings are located.

To the left is a parking garage; although garages are a better solution than surface lots, Tulsa should consider adding shops or restaurants to increase pedestrian activity. 


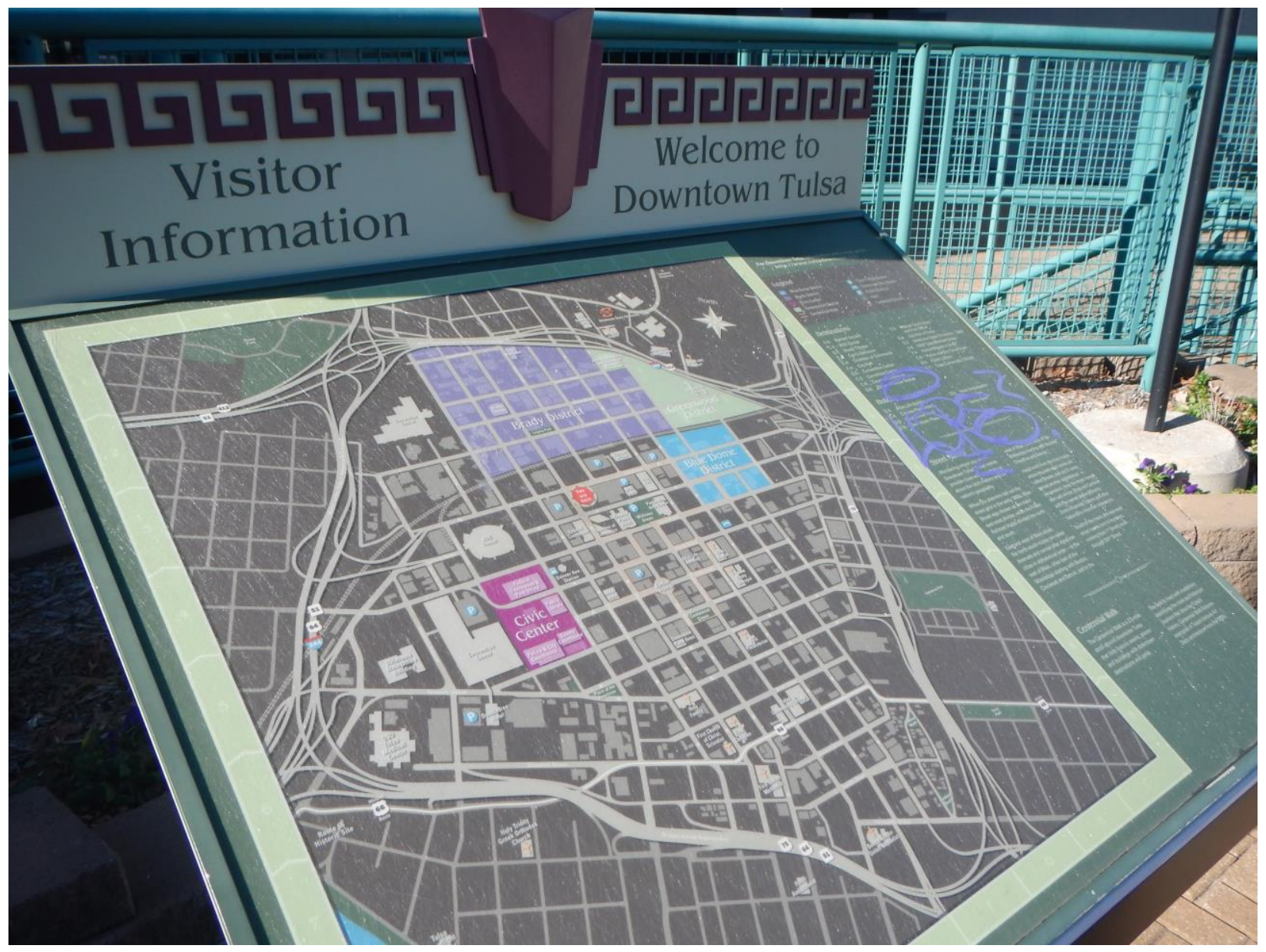

"Welcome to Downtown Tulsa" map immediately before Boulder Ave Bridge. Note the graffiti along the information key, as well as the outdated representation of the designated districts in the IDL. It is most likely that these visitor keys are only located in these districts. 


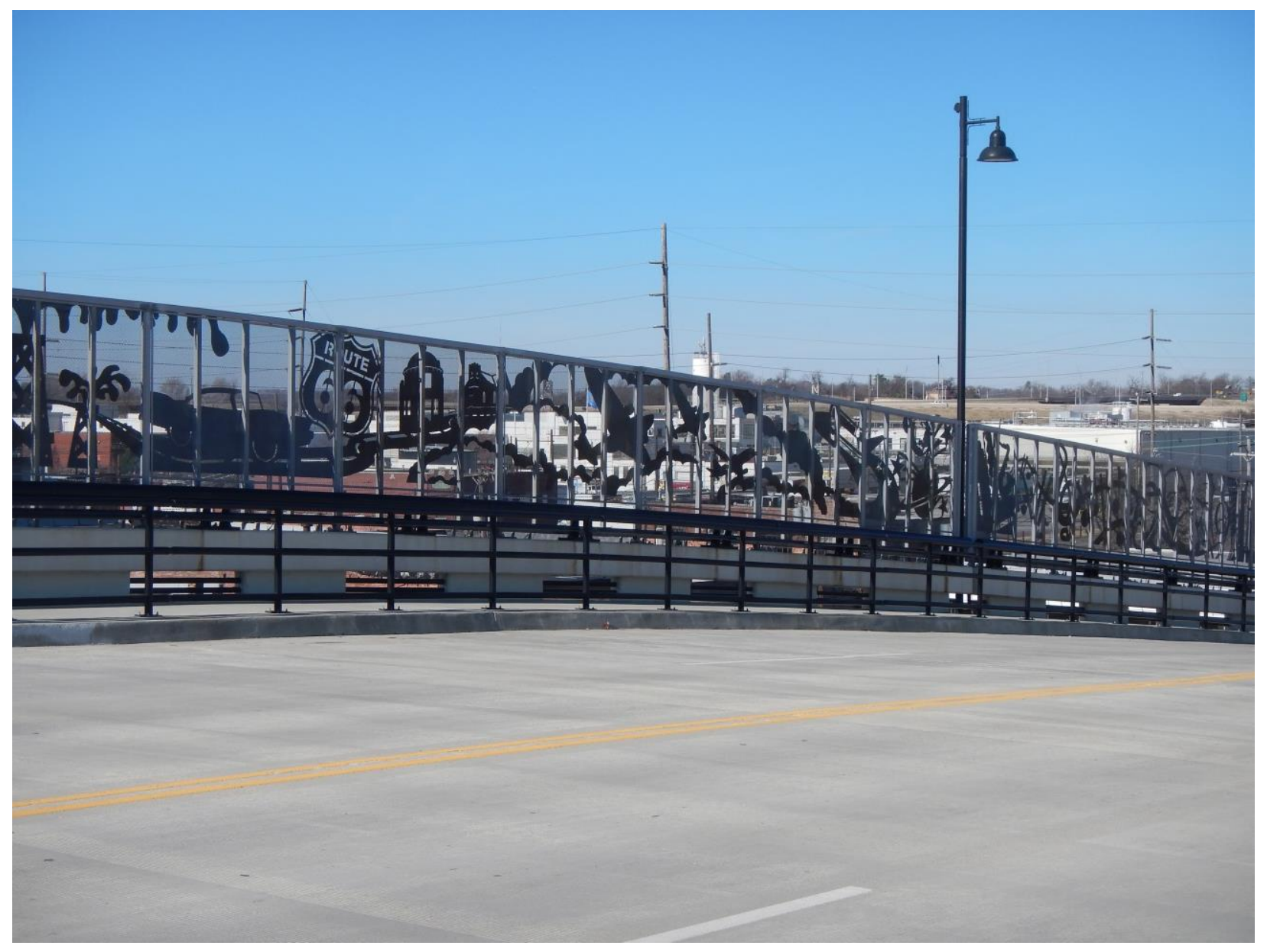

Boulder Avenue Bridge with imagery celebrating Historic Route 66. The fence and protected pedestrian walkway are newer additions to the bridge, which serves as one of the main connecting bridges between North and South Downtown. 


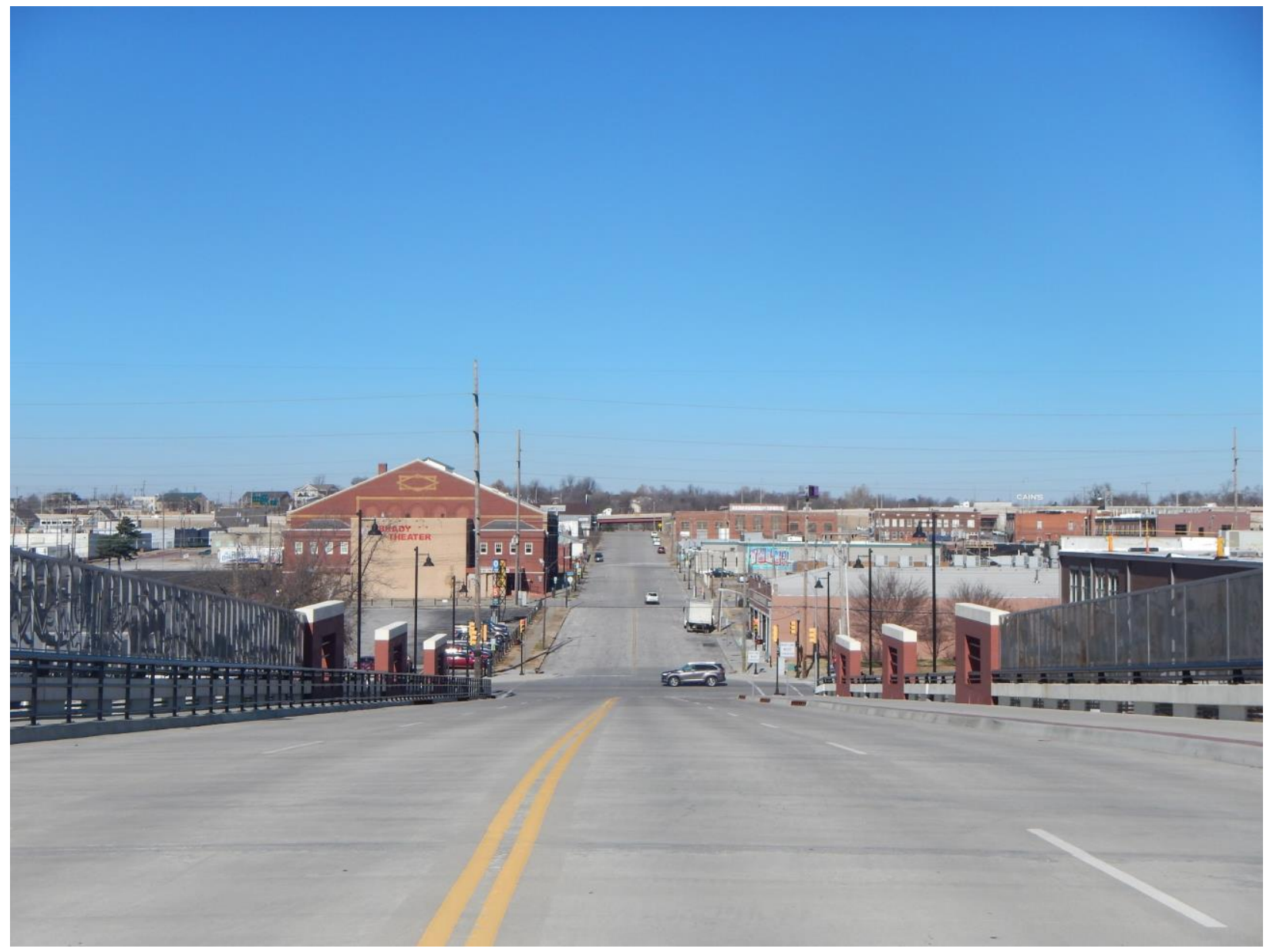

Brady Arts District from the Boulder Avenue Bridge. After the bridge (on left) is the Brady Theater, a convention hall listed on the National Register of Historic Places. Overpass bridges are a great opportunity to connect the North and south sections of the IDL, as well as highlight the culture and history of the city. 


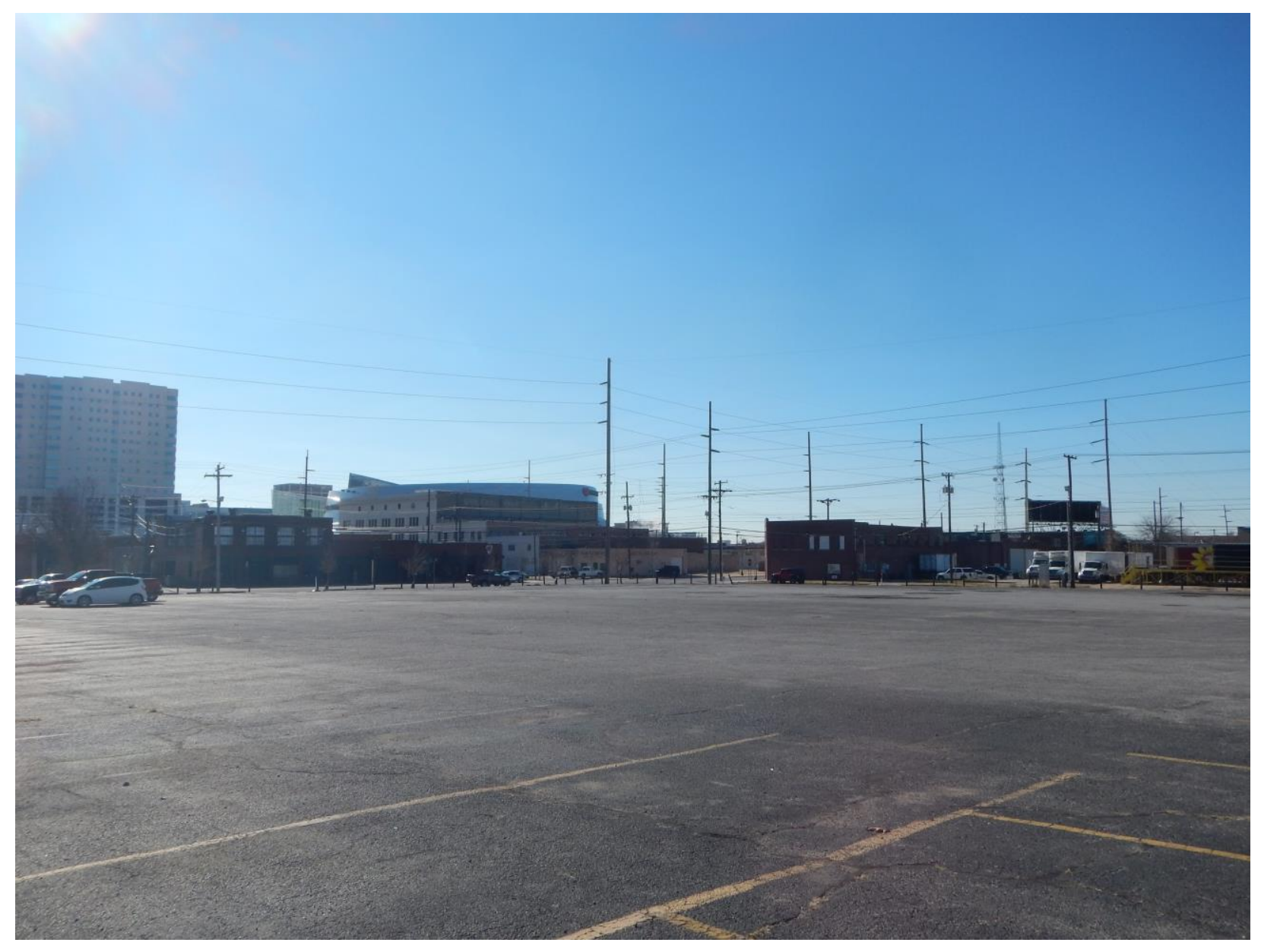

Parking lot immediately after the Boulder Bridge. Surface parking and vacant lots are still common in Downtown Tulsa. Currently there are two parks located in downtown; lots such as the one above could serve the city greatly in increasing green space and community spaces within downtown. BOK Center can be seen in the background. 


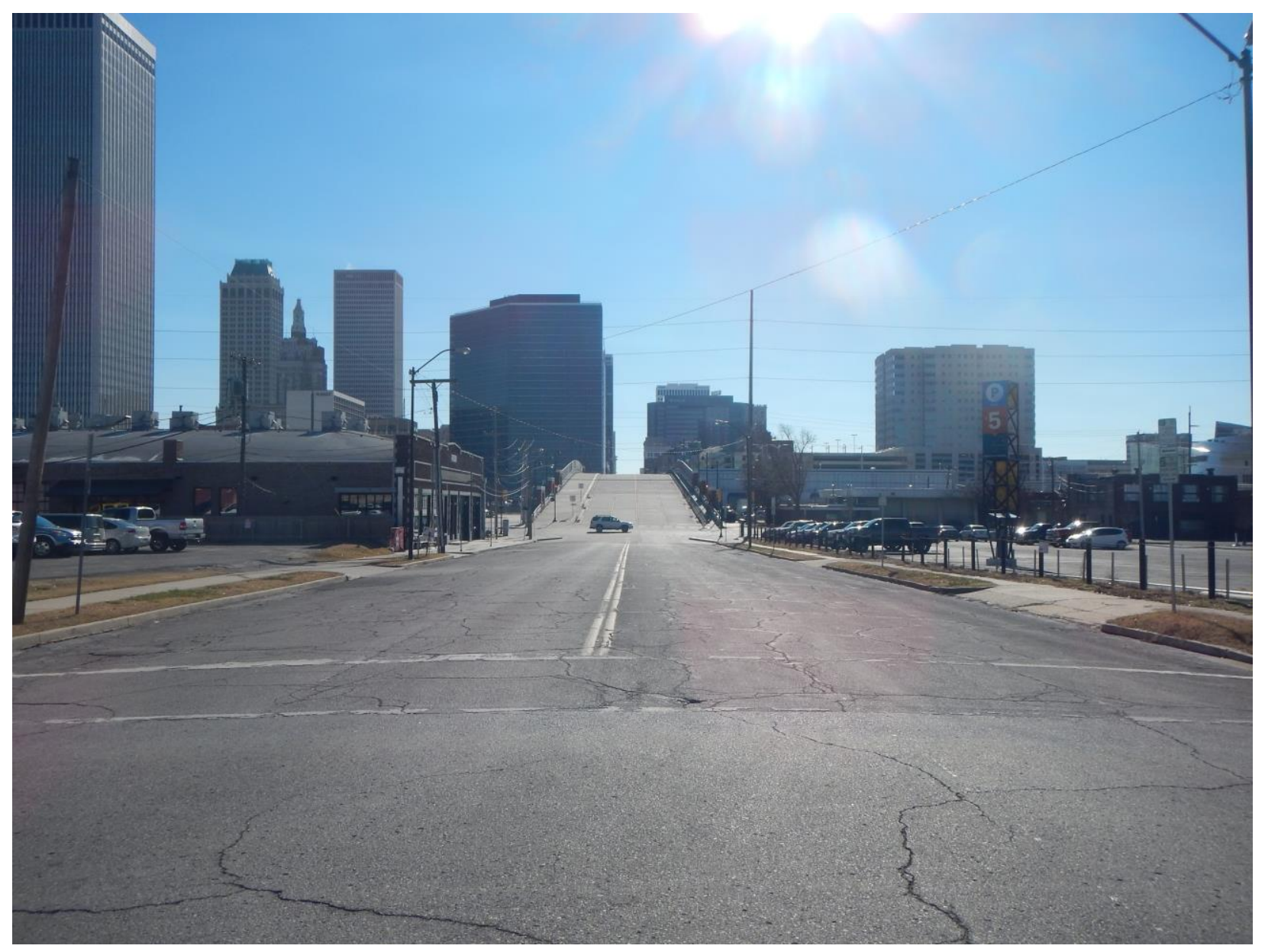

View of the Deco District, looking North on Boulder Avenue and M. B. Brady Street. Many of the streets within the IDL are wide enough to accommodate bike lanes or rapid transit bus lines. There is also an opportunity to widen sidewalks and create more pedestrian friendly spaces. 


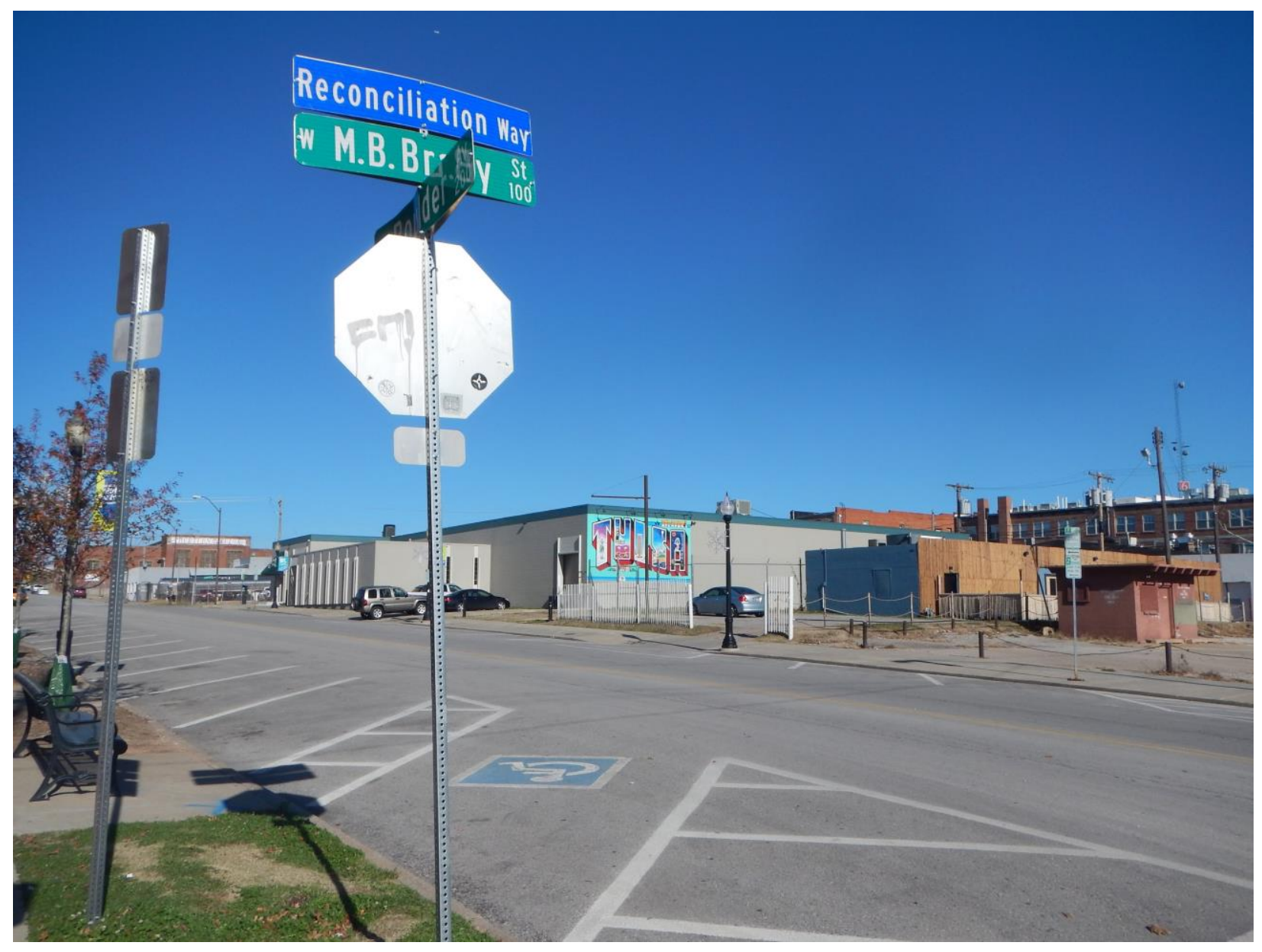

In 2013, Tulsa's citizens and leaders debated the name change for Brady Street, which was originally named after Tulsan and Ku Klux Klan leader Wyatt Tate Brady. It was changed to honor the New York Civil War photographer Mathew B. Brady in order to prevent rebranding of the Brady Arts District. The compromise was suggested by Blake Ewing, City Councilor for District 1 . The decision continues to be highly contested, even after the street was coined "Reconciliation Way" and has forced the city to rethink its branding and imagery. 


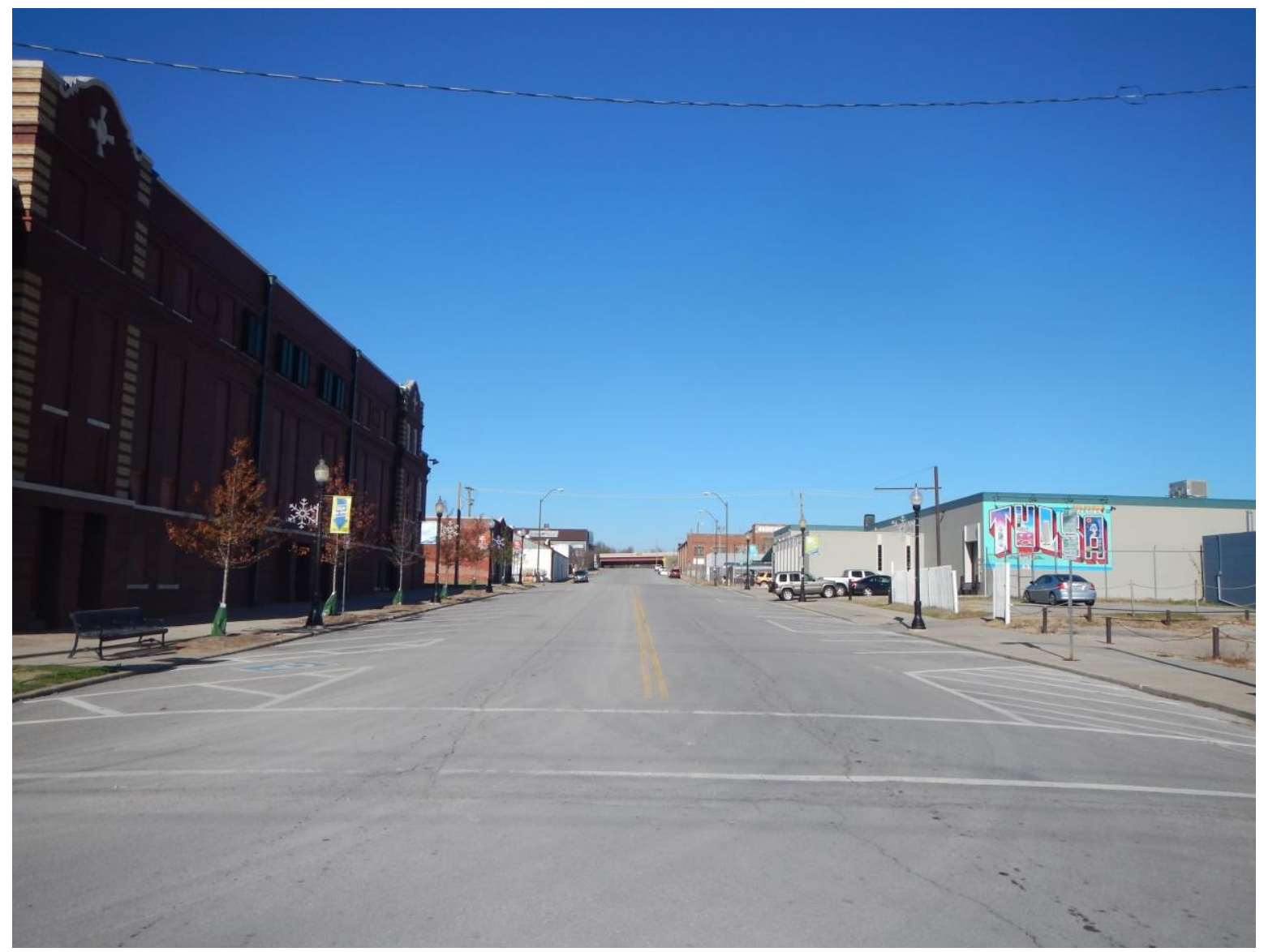

The Brady Arts District: looking south on Boulder Avenue and M. B. Brady Street. Benches and seasonal decorations outside of Brady Theater (on left) help to create a more inviting streetscape. On the right is a mural celebrating the city; it is on private property and is surrounded by fences and a vacant lot.

Street art can be an excellent way to invite citizens to interact with their city, however not having it accessible creates an issue of privilege and does not allow the art to be fully celebrated by the city. Although street parking is important, space use for pedestrians and alternative transportation should be given higher priority due to the exorbitant amount of surface lots in the area.

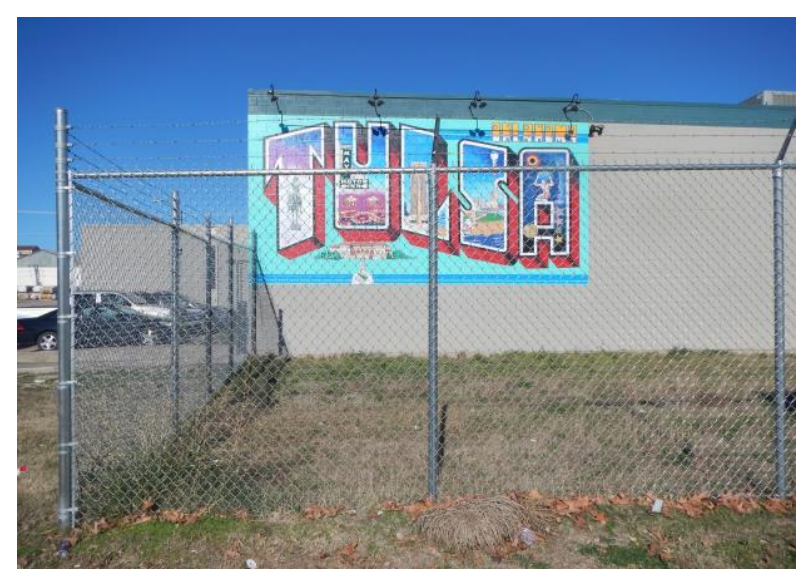




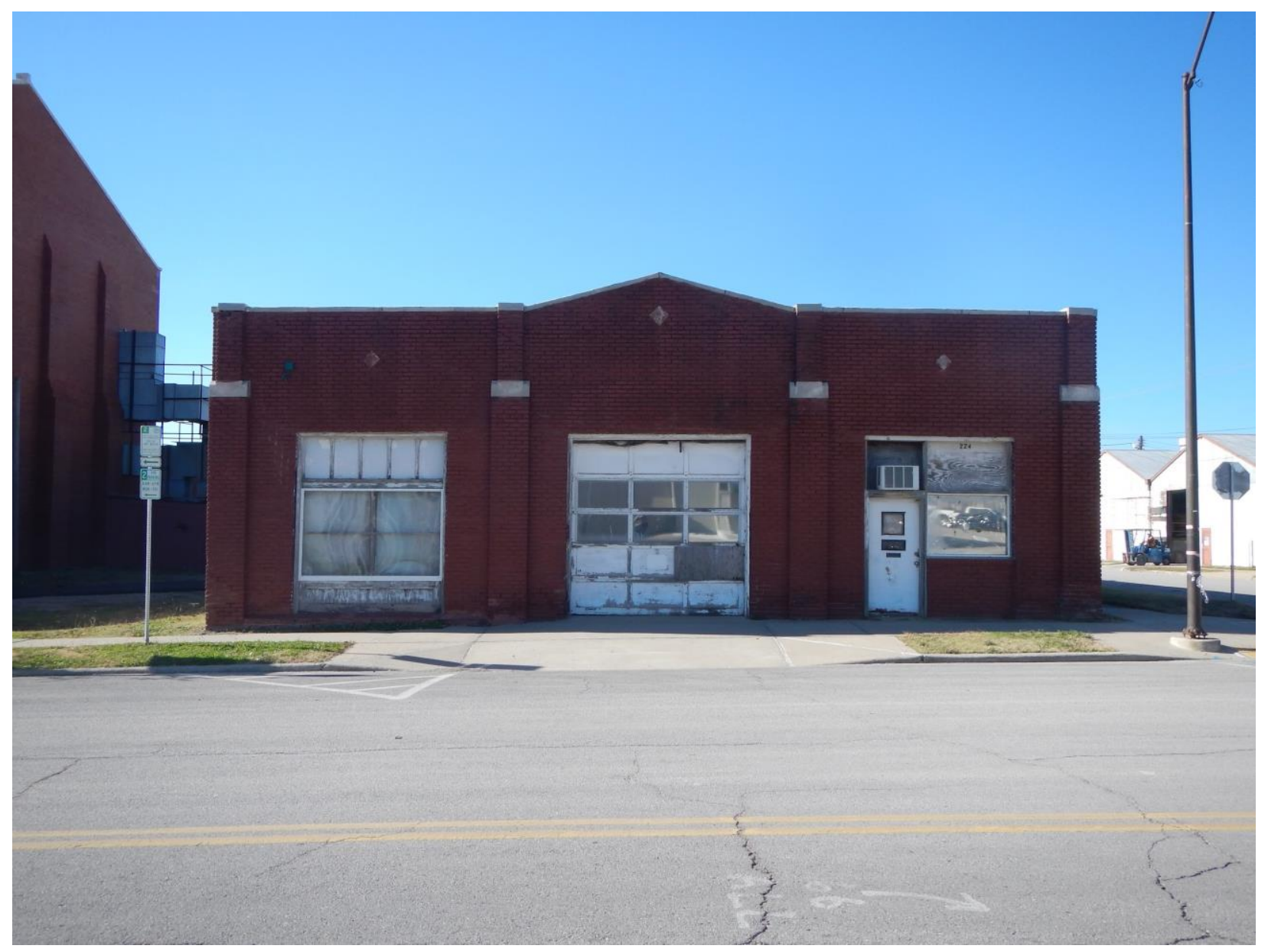

Many of the vacant buildings in the Brady Arts District are still in good condition. Warehouses are common and are being converted into restaurants, bars, and art studios. Rehabilitation instead of destruction of these buildings will assist in maintaining the character of the district. 


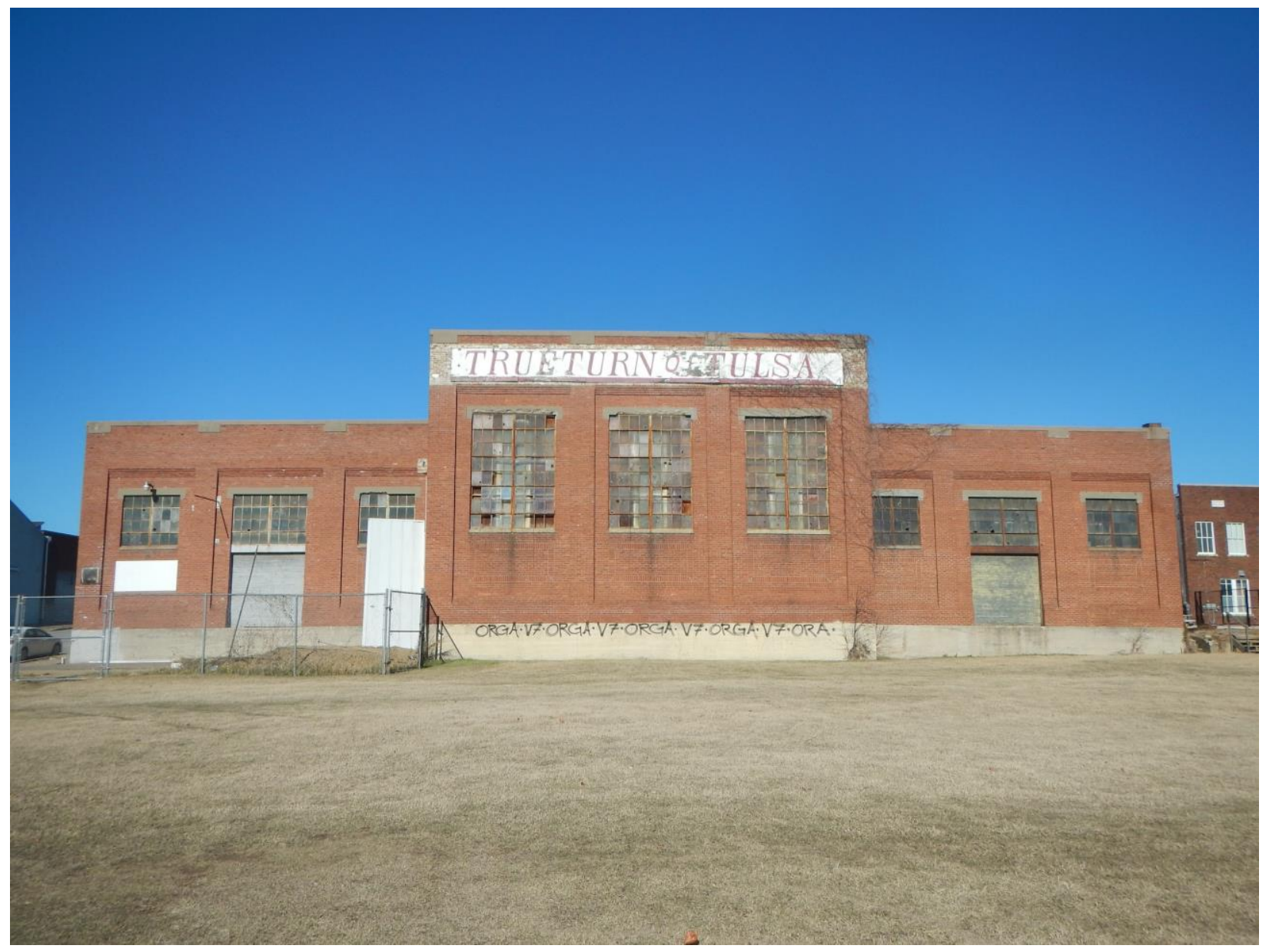

The "True Turn of Tulsa" building, located at $421 \mathrm{~N}$ Boulder Ave, has remained vacant for many years. The building has been identified as eligible for the National Register of Historic Places. Brady Arts District is quickly becoming a district known for restaurants, nightclubs, art spaces, and housing. This building, along with the lawn pictured, could serve as a public market for downtown. Basic amenities are still lacking in downtown and the need for a grocery store is becoming more apparent. True Turn of Tulsa should be utilized as an anchor for the district and also invite Tulsans and visitors to the space. A public market, with a variety of space users and available goods and services, is recommended over a chain grocery store. 


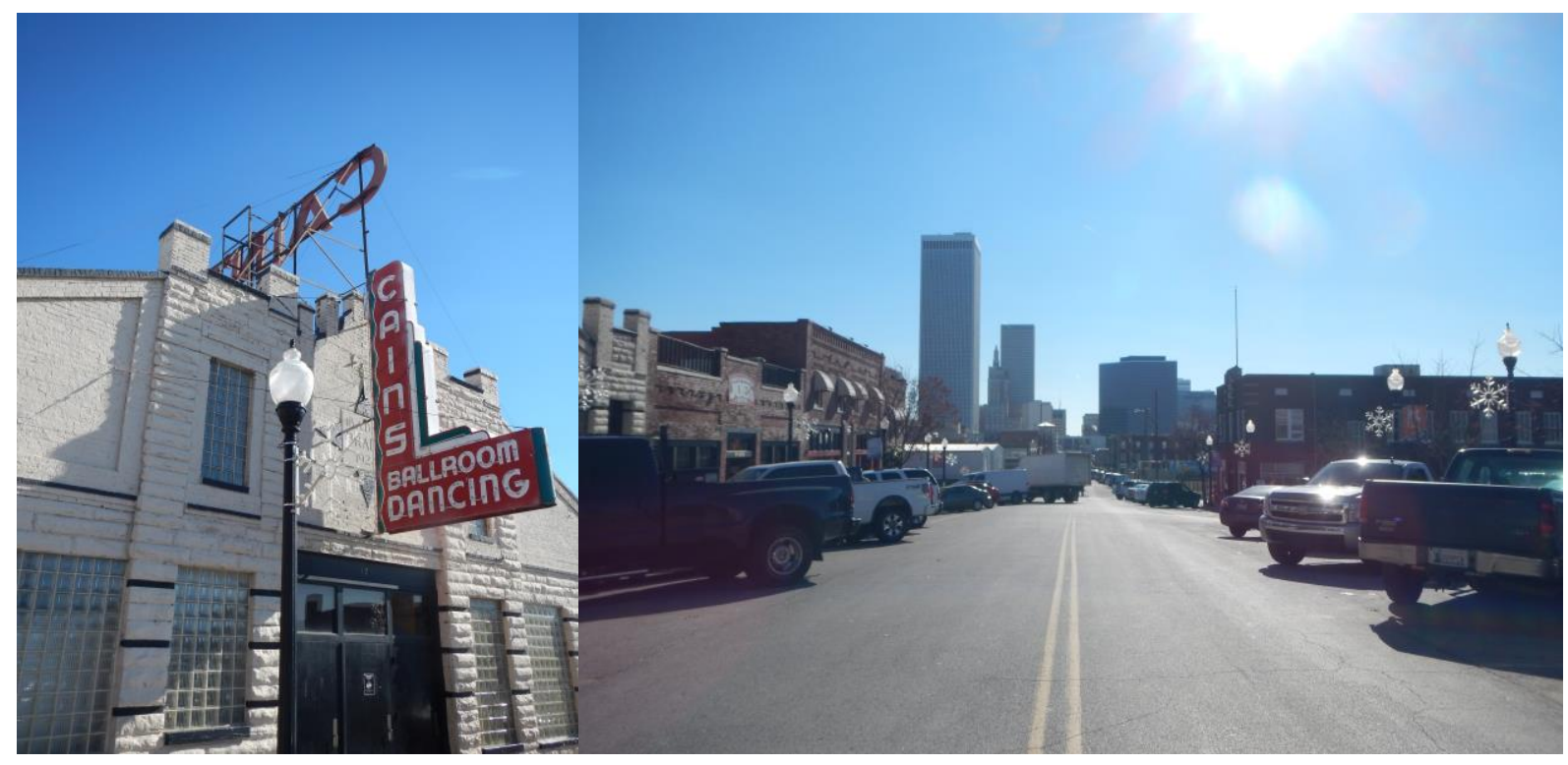

Facing south on N Main Street and Easton Avenue, directly outside the historic Cain's Ballroom. Main Street is known for the nightclubs, bars, and restaurants that attract Tulsans and visitors to the Brady District. The "True Turn of Tulsa" building's lawn is accessible further south along N Main Street.

Due to this area's popularity as an entertainment district, street parking should be removed in order to create more pedestrian space. Traffic and parking are issues for the area; a parking garage along the periphery would allow for less automobile use and free up street space for bicycles or a trolley. 


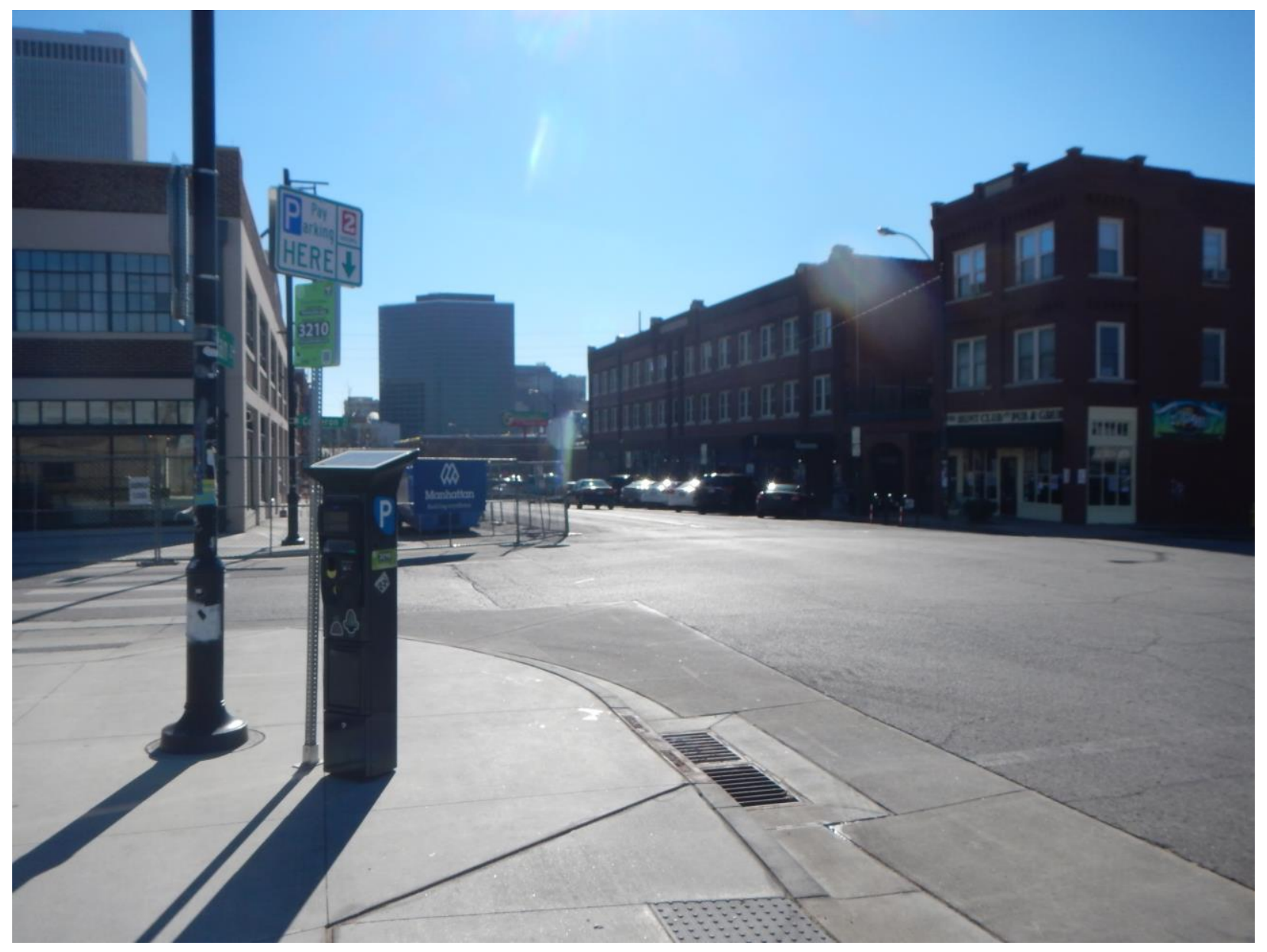

Paid parking is beginning to be introduced in high traffic areas such as the Brady Arts District. Bars and restaurants (right) line the street level of historic apartment buildings. New construction (left) aims to complement the architecture styles of the district. Location: N Main St and Cameron Avenue (facing south). 


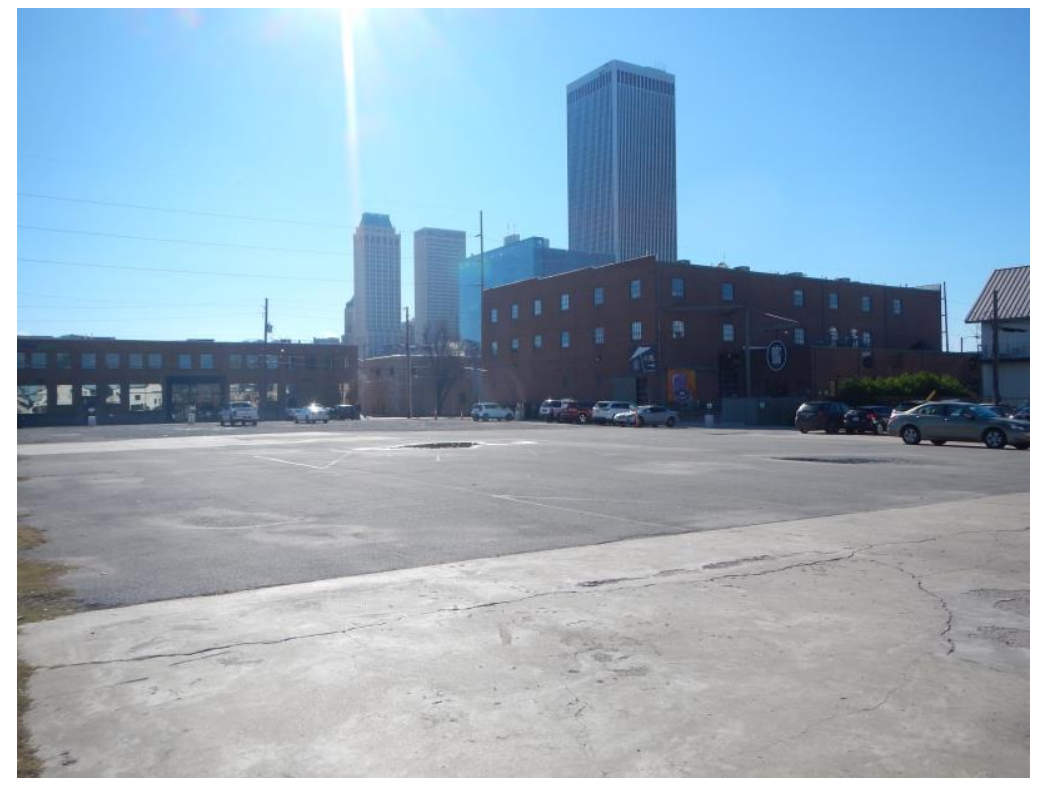

Vacant lots directly across from the ONEOk Field at N Archer Ave and Elgin Street. The opportunity to create a cultural space which honors the legacy of Greenwood would be ideal here. Although there are memorials and monuments north of ONEOk Field, visitors to the stadium may not have an understanding of the deep history of the area.

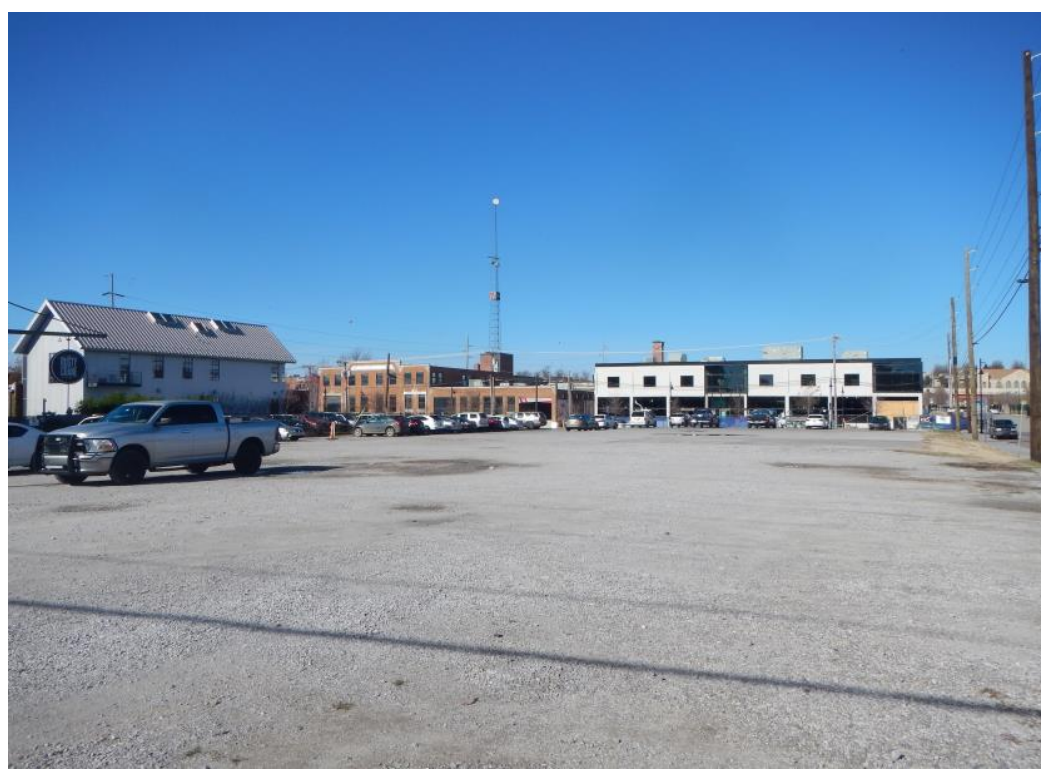




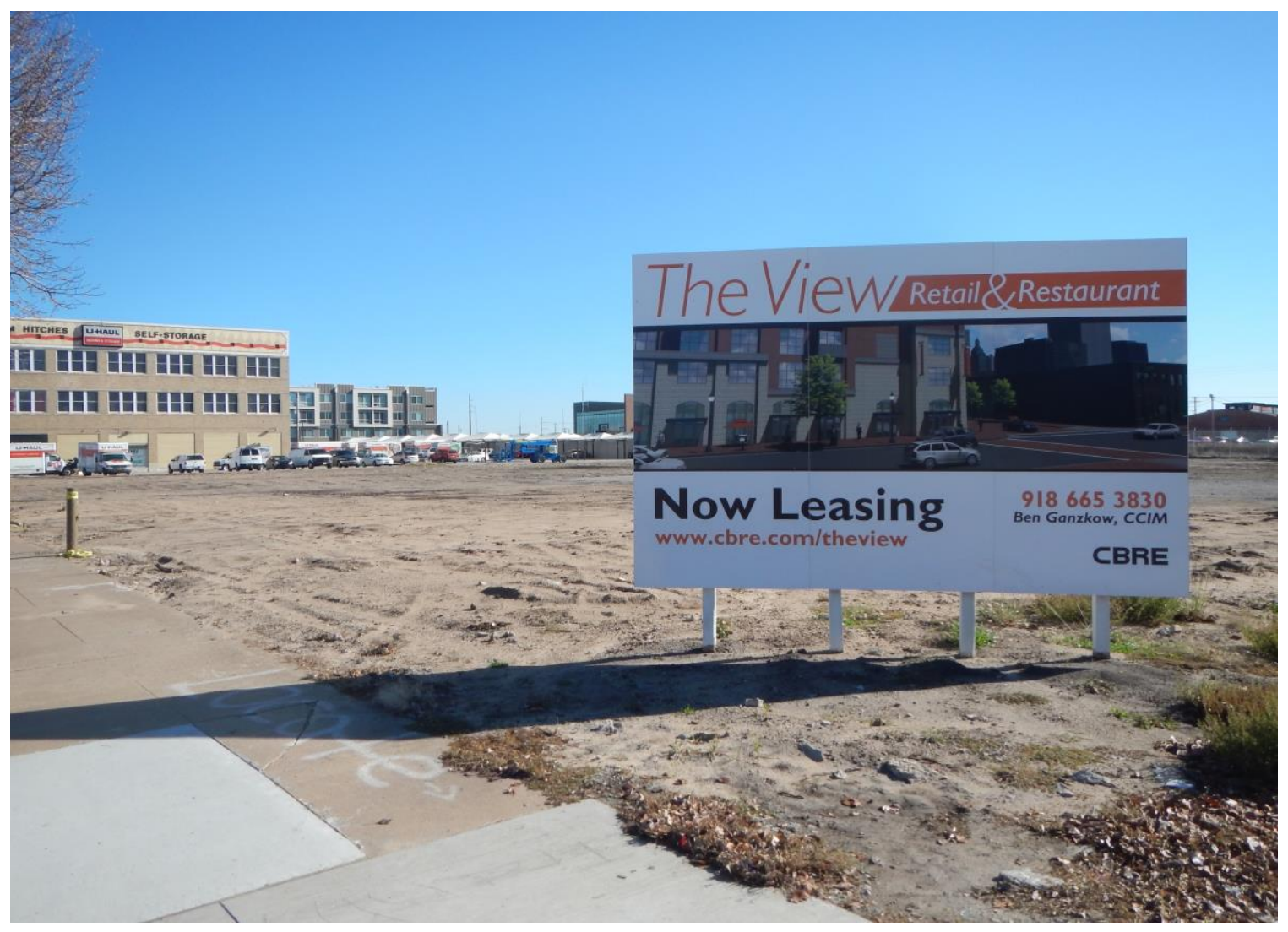

Another vacant lot, directly south of ONEOk Field at E Archer St and N Elgin Avenue. E Archer Street served as the delineation between Greenwood and Downtown Tulsa, and was the "battlefront" for the 1921 Tulsa Race Riots. Caution should be used when developing within Greenwood District and surrounding blocks. 


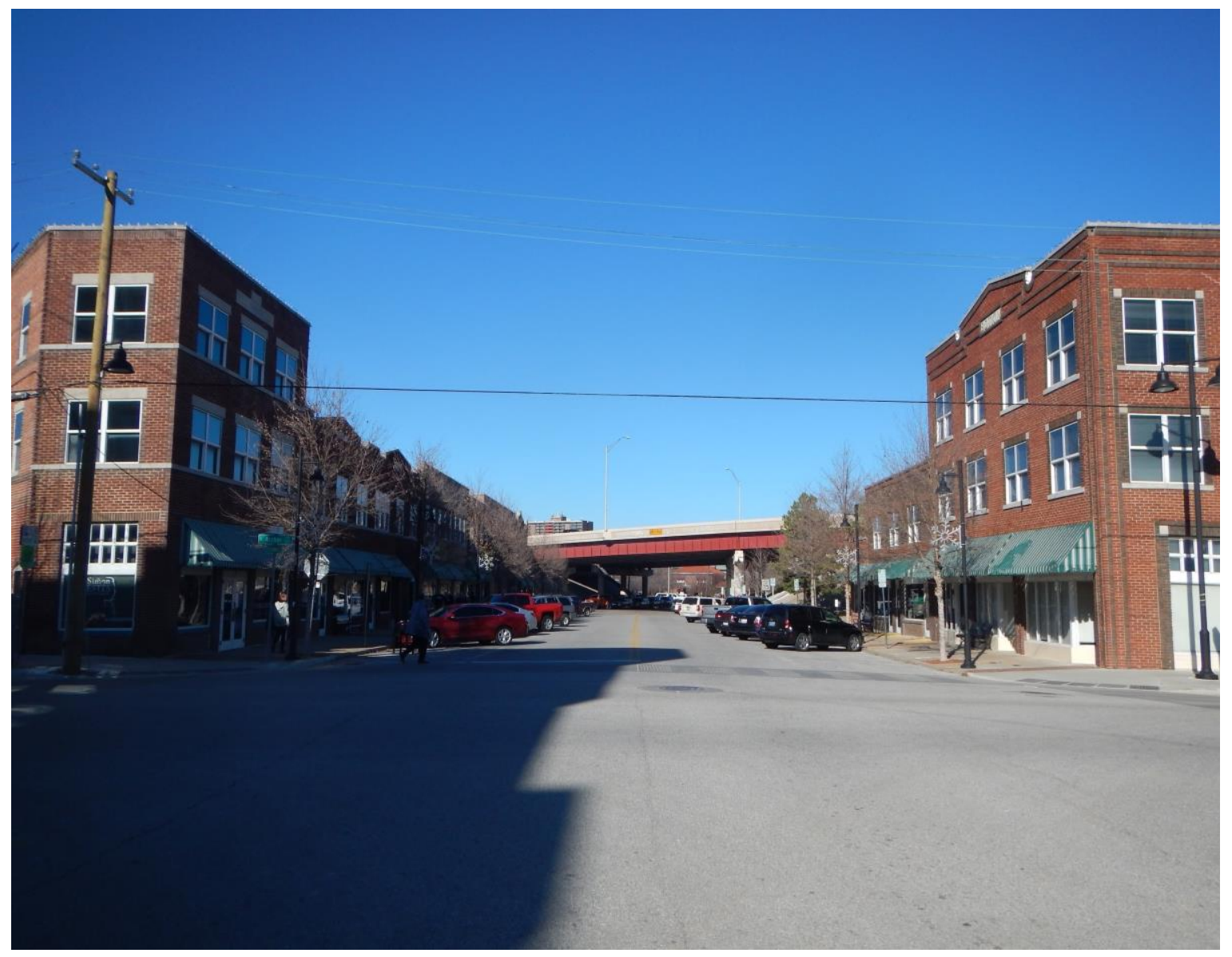

Historic N Greenwood Avenue. To the left (not pictured) is ONEOk Field. The project has breathed life into a section of downtown, yet does not directly serve Black residents of Tulsa or contribute to their community in a meaningful way. Downtown has an abundance of vacant lots; the decision to construct the new baseball field in this district should not be ignored. Directly after the highway is the Greenwood Cultural Center and John Hope Franklin Center for Reconciliation. 


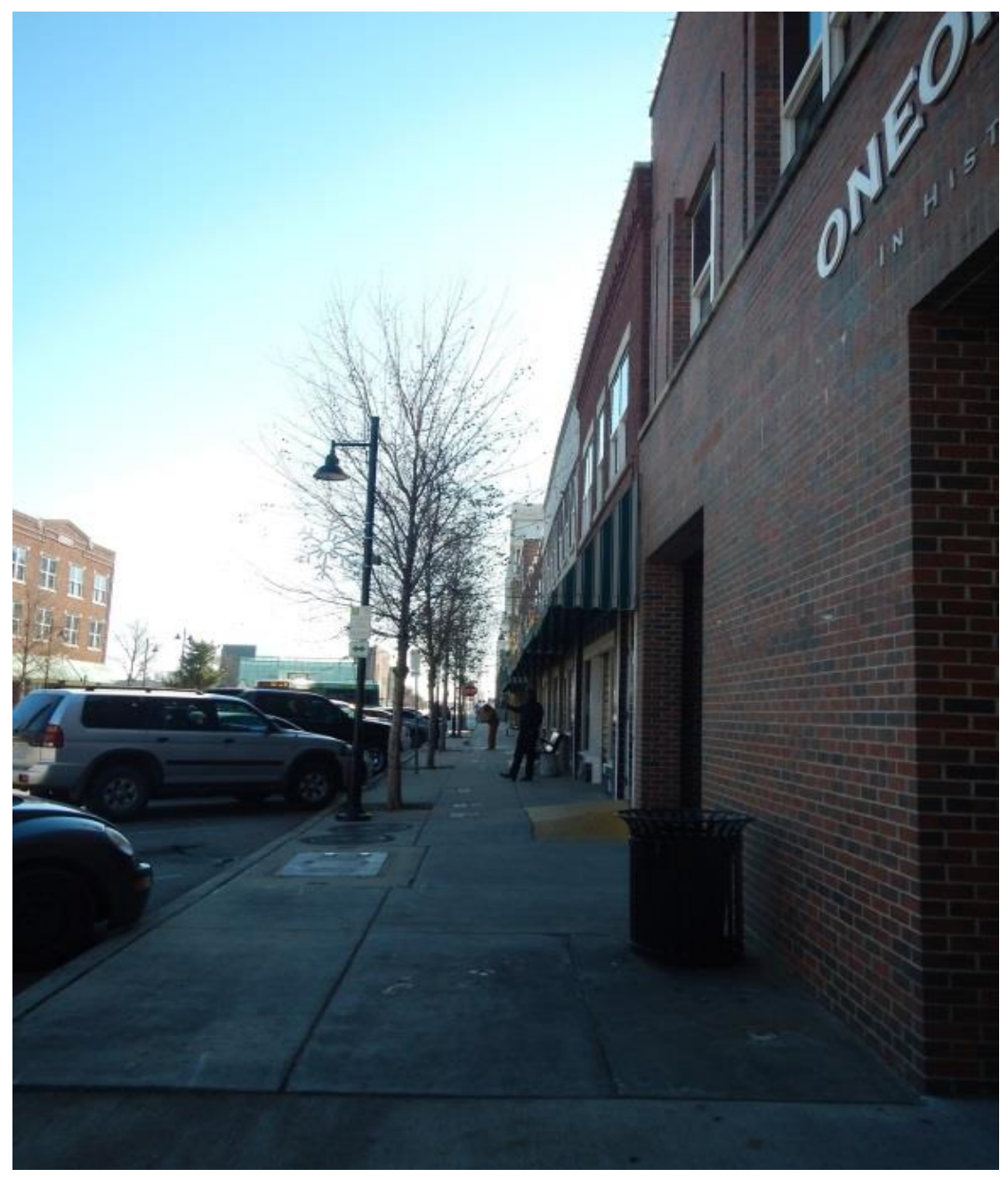

Directly to the right in this image is an entrance to ONEOk Field. In an area with minimal storefront space, the intentional decision to create an extra entrance, along with a restaurant not owned by Greenwood/North Tulsa residents, should not be overlooked. Although the entrance helps connect Greenwood District to the Brady Arts District, it further diminishes the economic capacity of the area.

Throughout my two hour walk, I saw less than 10 people. Greenwood Avenue was the only street which people were talking and occupying the space, not just travelling through from one destination to another. This gentleman was the only person who conversed with me; when he found out I was creating a photo tour of the area he asked if he could be in the picture. 


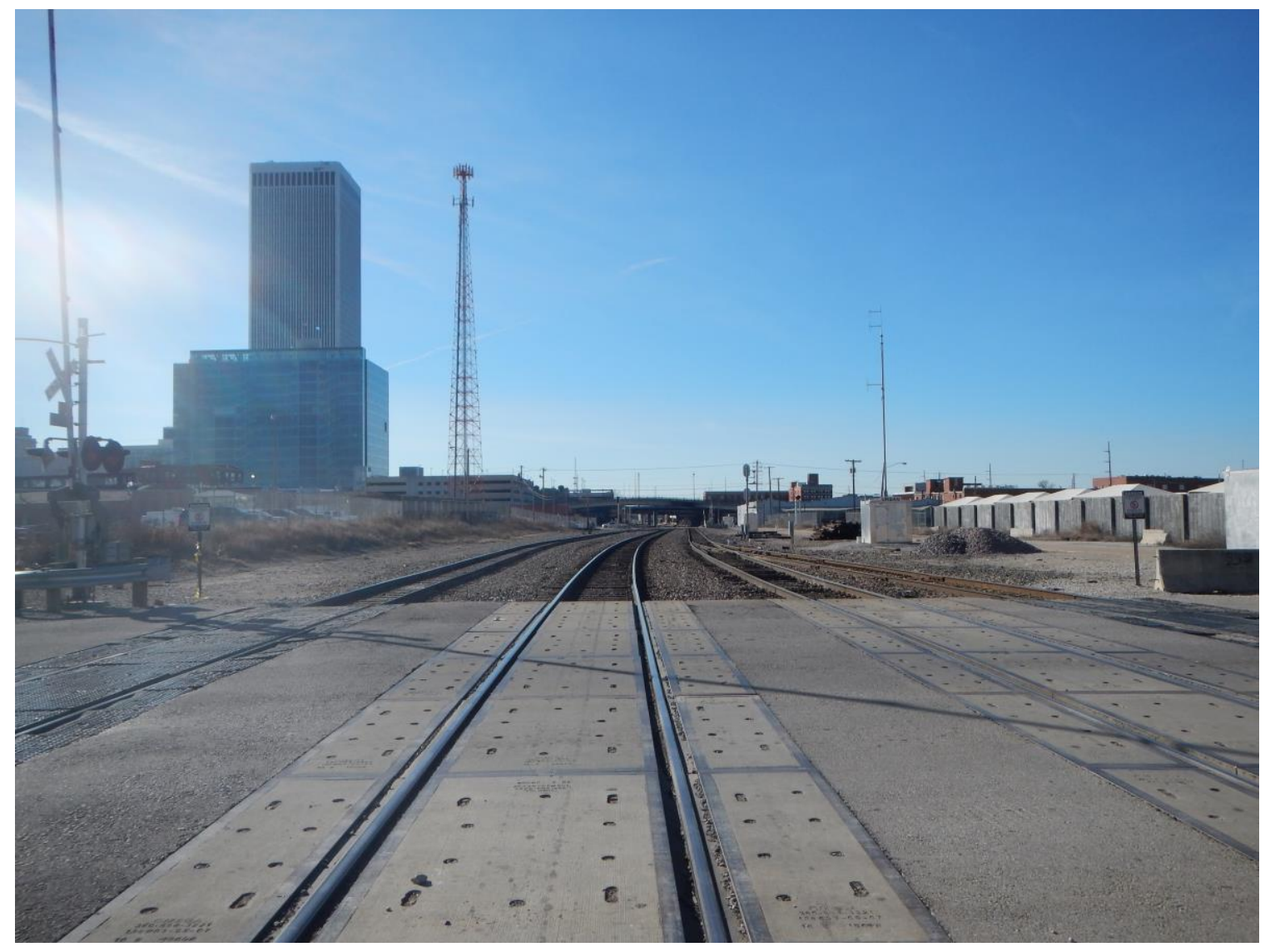

Railroad tracks separating north and south downtown (on N Greenwood Avenue). There are often long waiting periods when a train is passing through downtown. More frequent overpasses for bicyclists and pedestrians are recommended so that the two sections can be more connected, thus enhancing walkable urbanism within the IDL. 


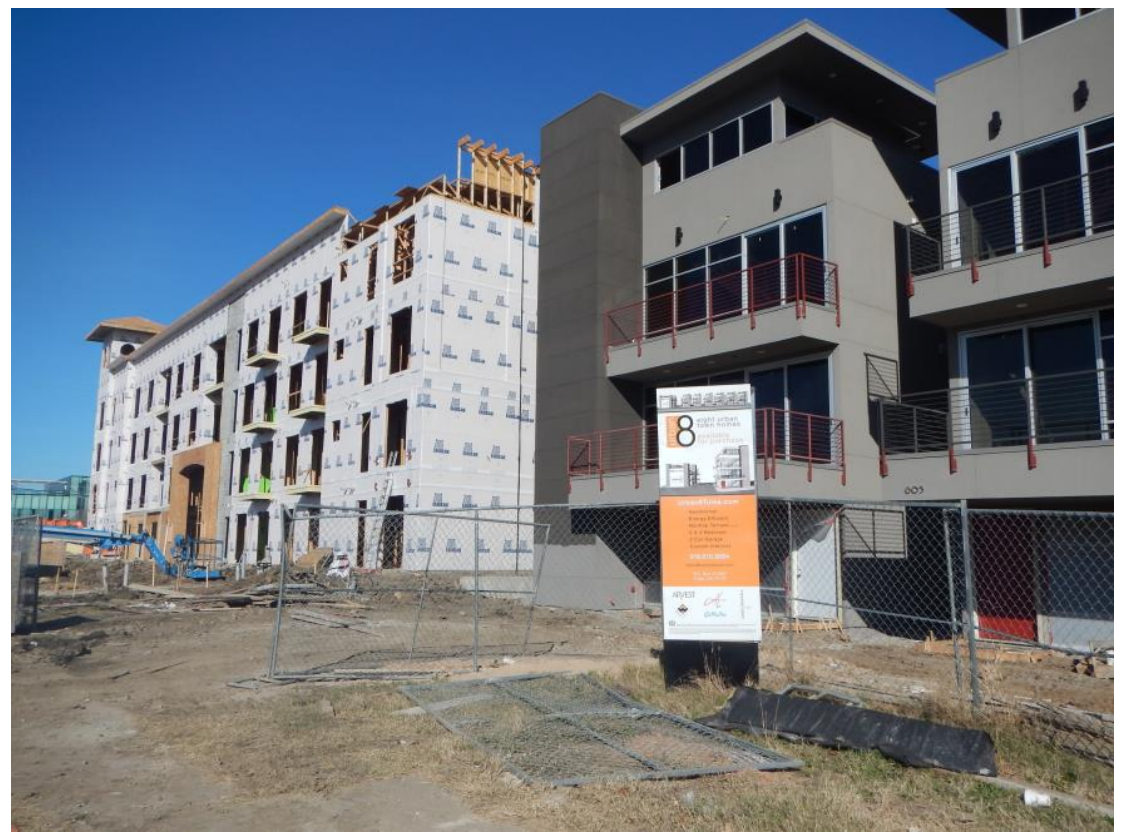

New construction (at S Greenwood Ave and E 3rd St) in East Village is being marketed towards affluent empty nesters. Urban 8 (in gray) are townhomes for sale with prices starting at $\$ 875,000$. Although relatively new, East Village has created a clear brand for the area. The district is located in an area with more vacant lots and buildings; the current risk of displacing another community is minimal. The arrival of empty nesters will hopefully increase the tax base and allow for beautification and community development projects throughout the city.

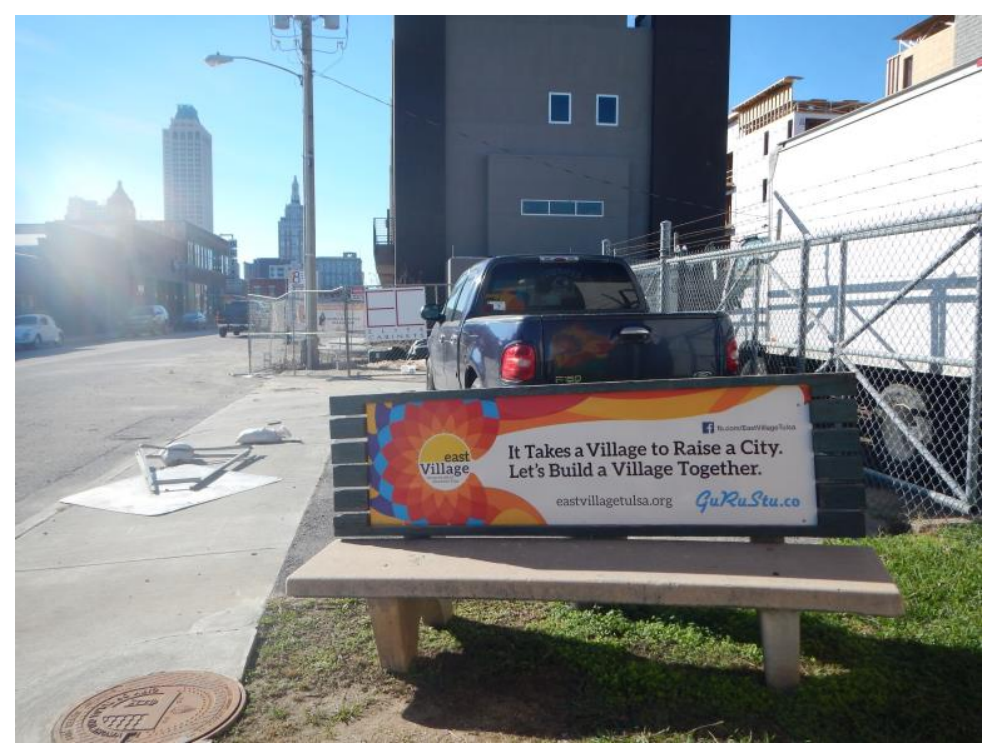




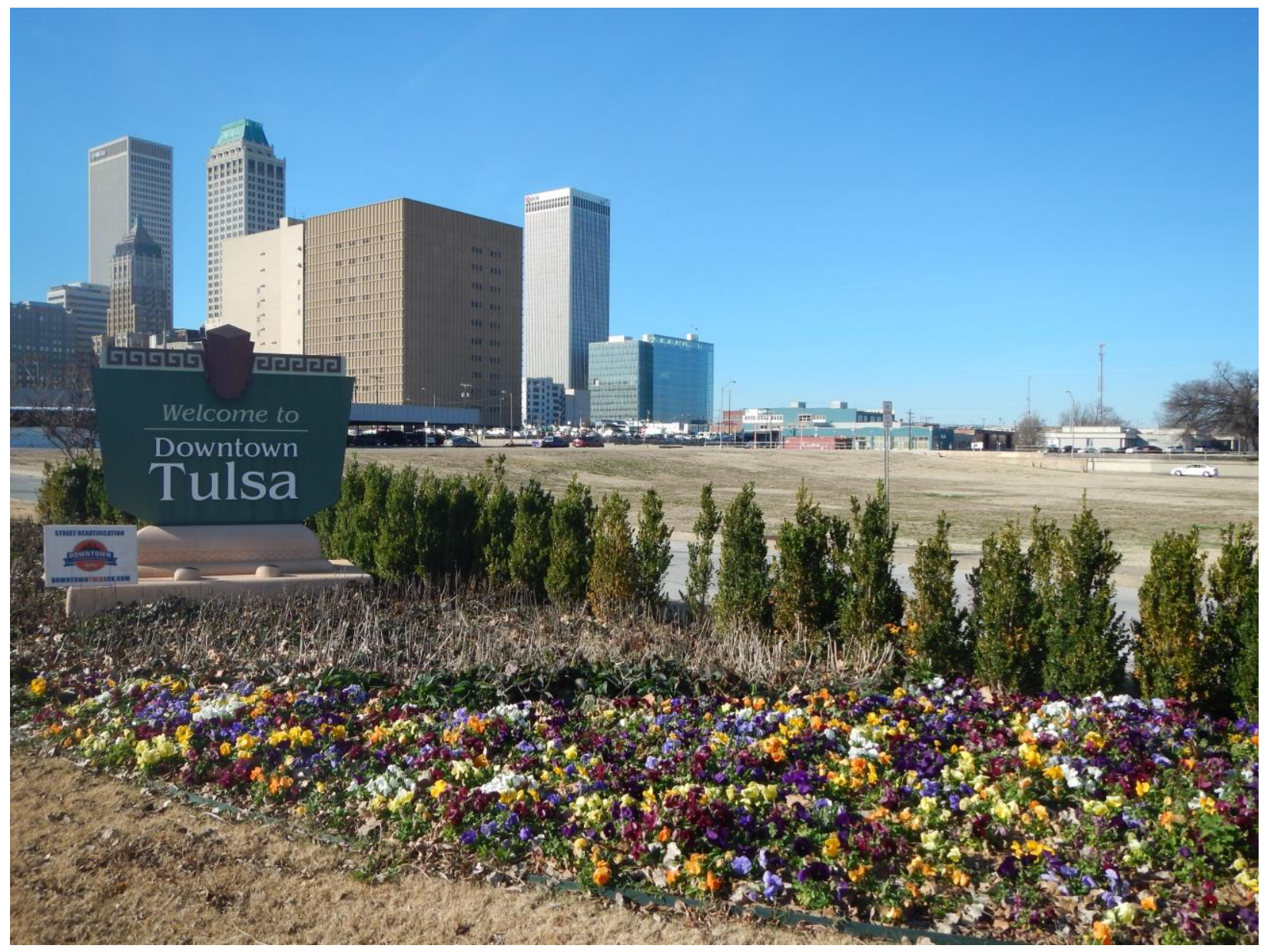

The southeast entrance into downtown from Cherokee Expressway (I-75). Beautification and placemaking projects such as these are necessary along all entrances along the IDL. The vacant lots surrounding this entrance would make excellent locations for community spaces, farmers markets, or other space uses which invite visitors and citizens to explore the IDL. 
DOWNTOWN REVITALIZED, COMMUNITY ORGANIZED

\section{APPENDIX C: HISTORICAL MAPS OF TULSA}

The following maps were scanned from historical documents made available from Tulsa City-County Library Archives Department.

Maps from Business Relocation and Downtown Tulsa Renewal (n.d) by Judy Shriver

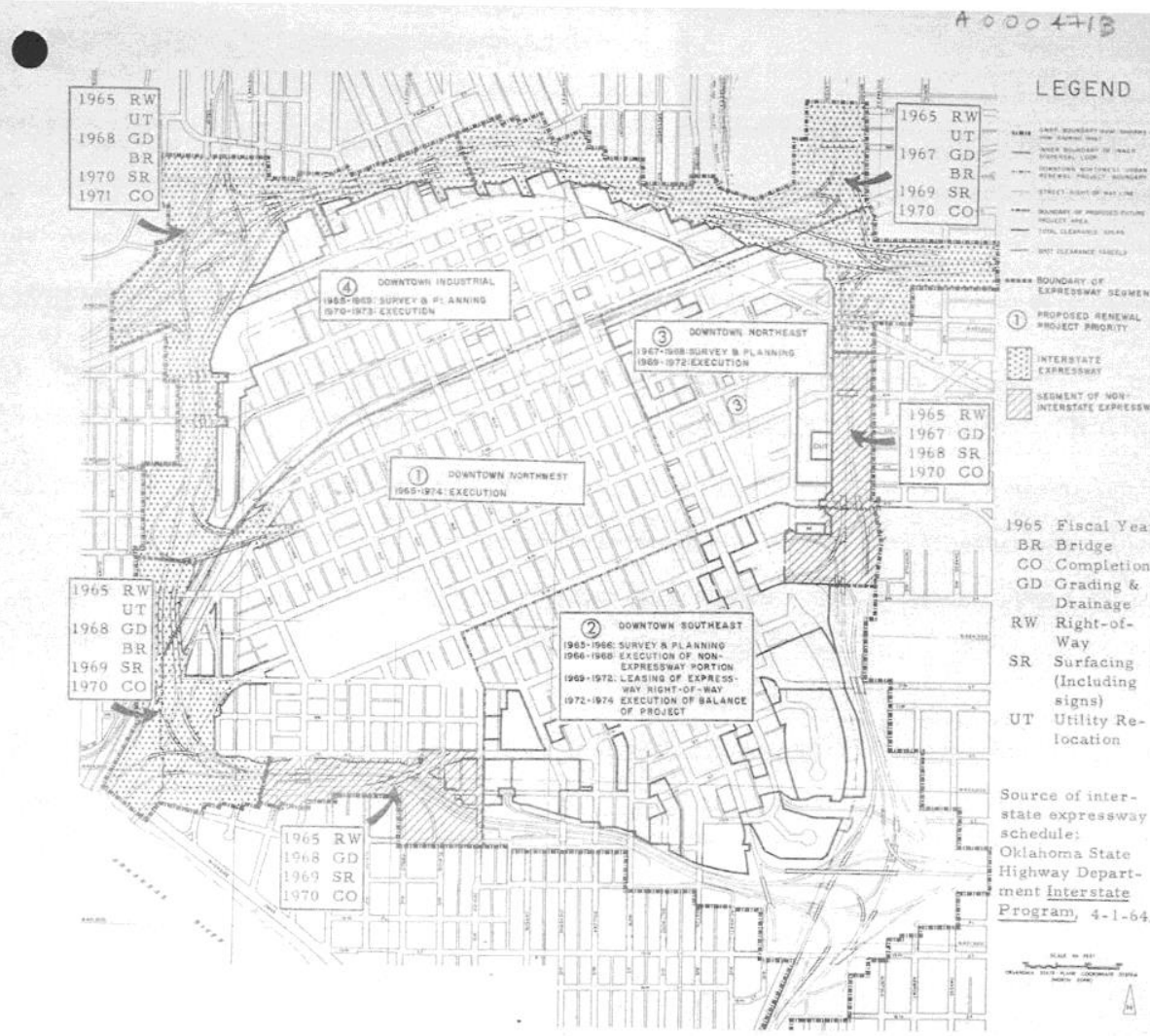

PROPOSED SCHEDULING OF GENERAL NEIGHBORHOOD RENEWAL PLAN PROJECTS 


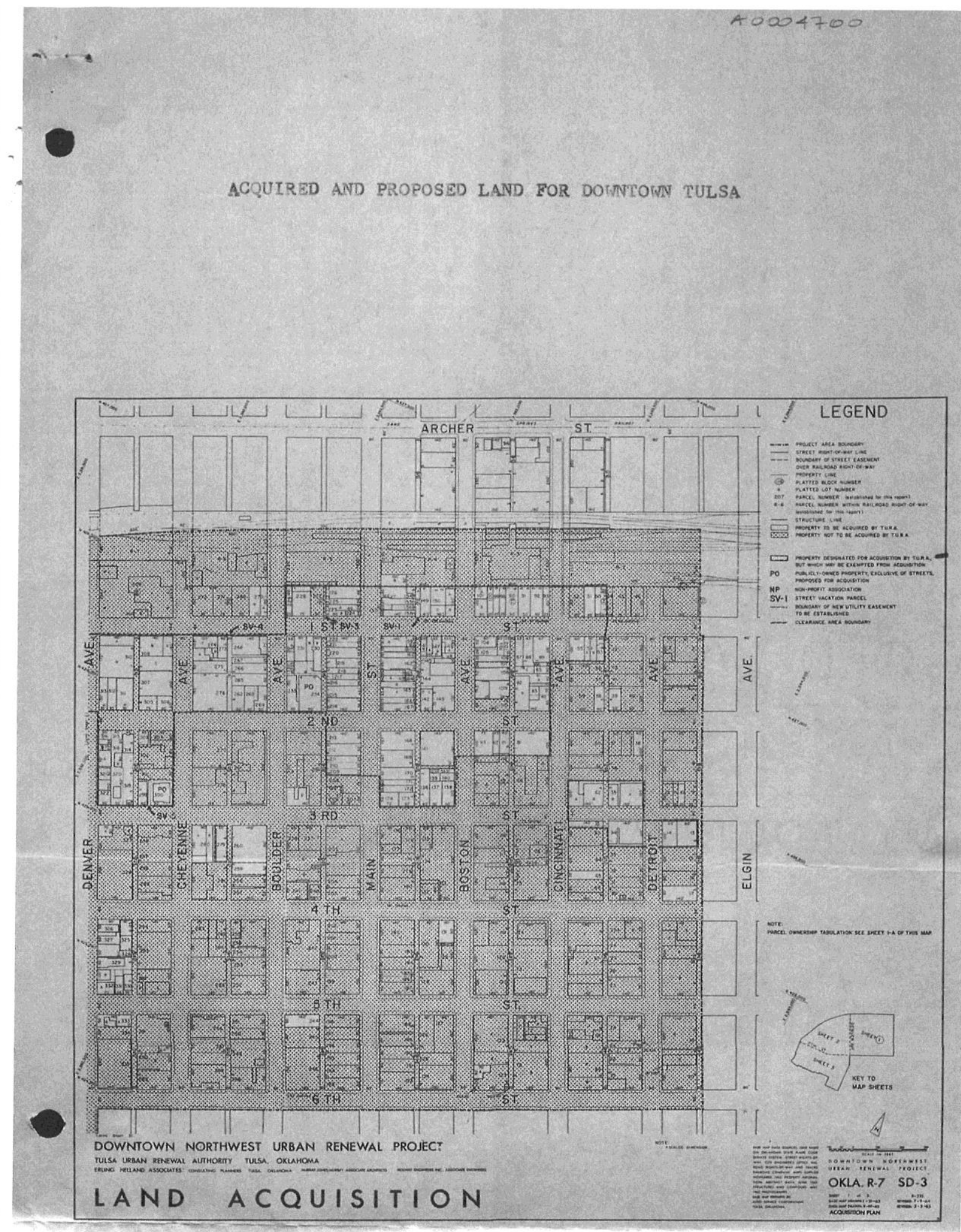




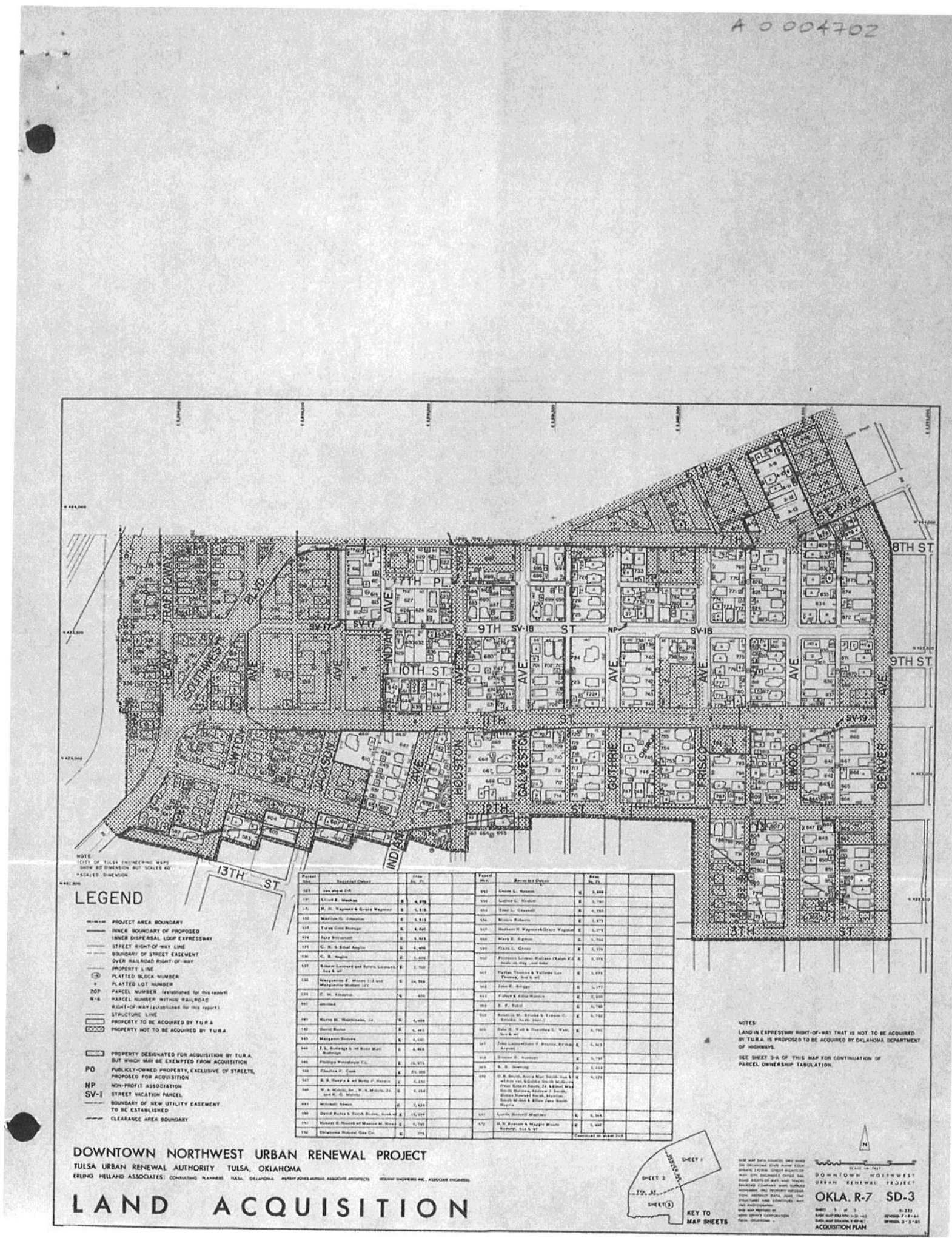




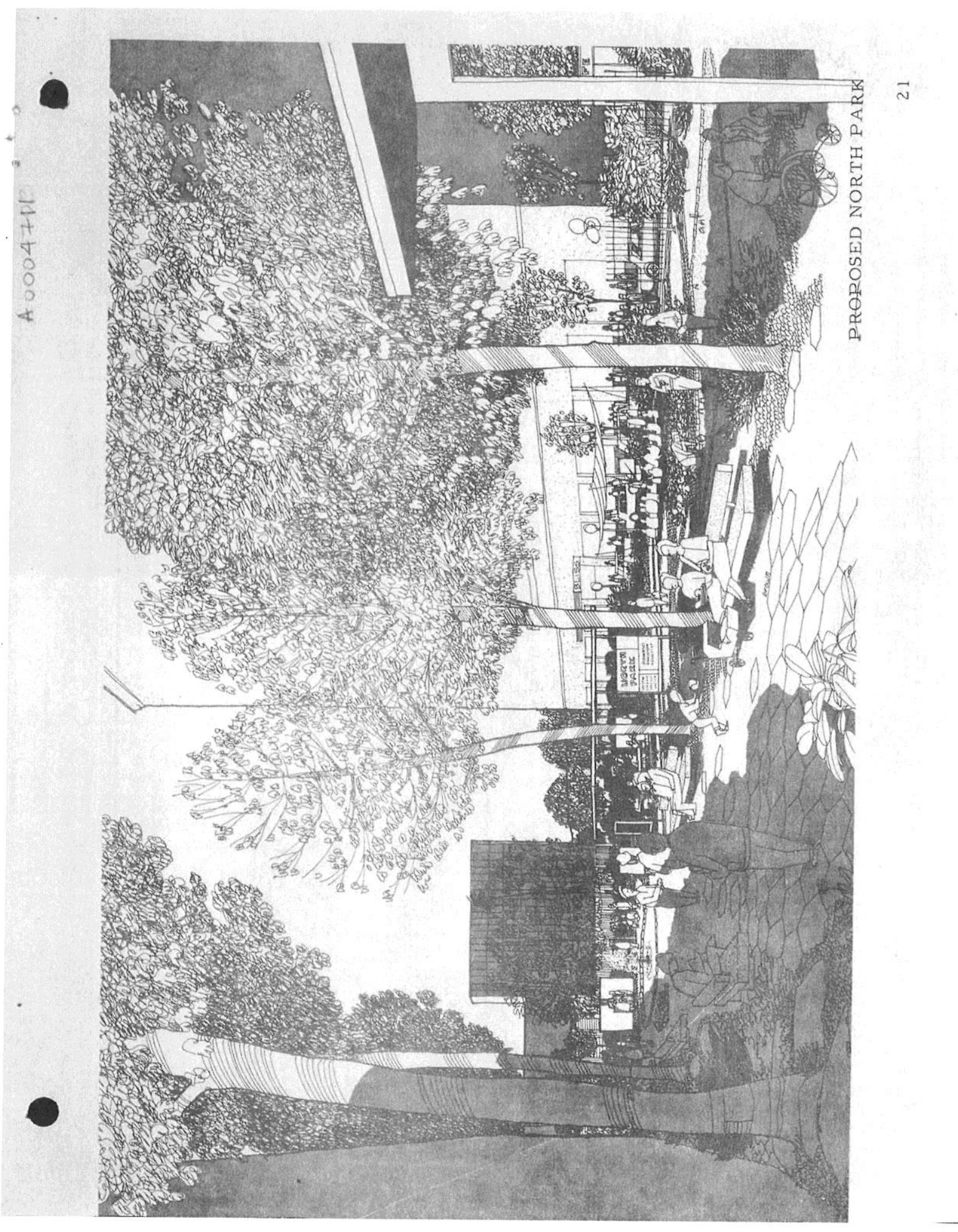


DOWNTOWN REVITALIZED, COMMUNITY ORGANIZED

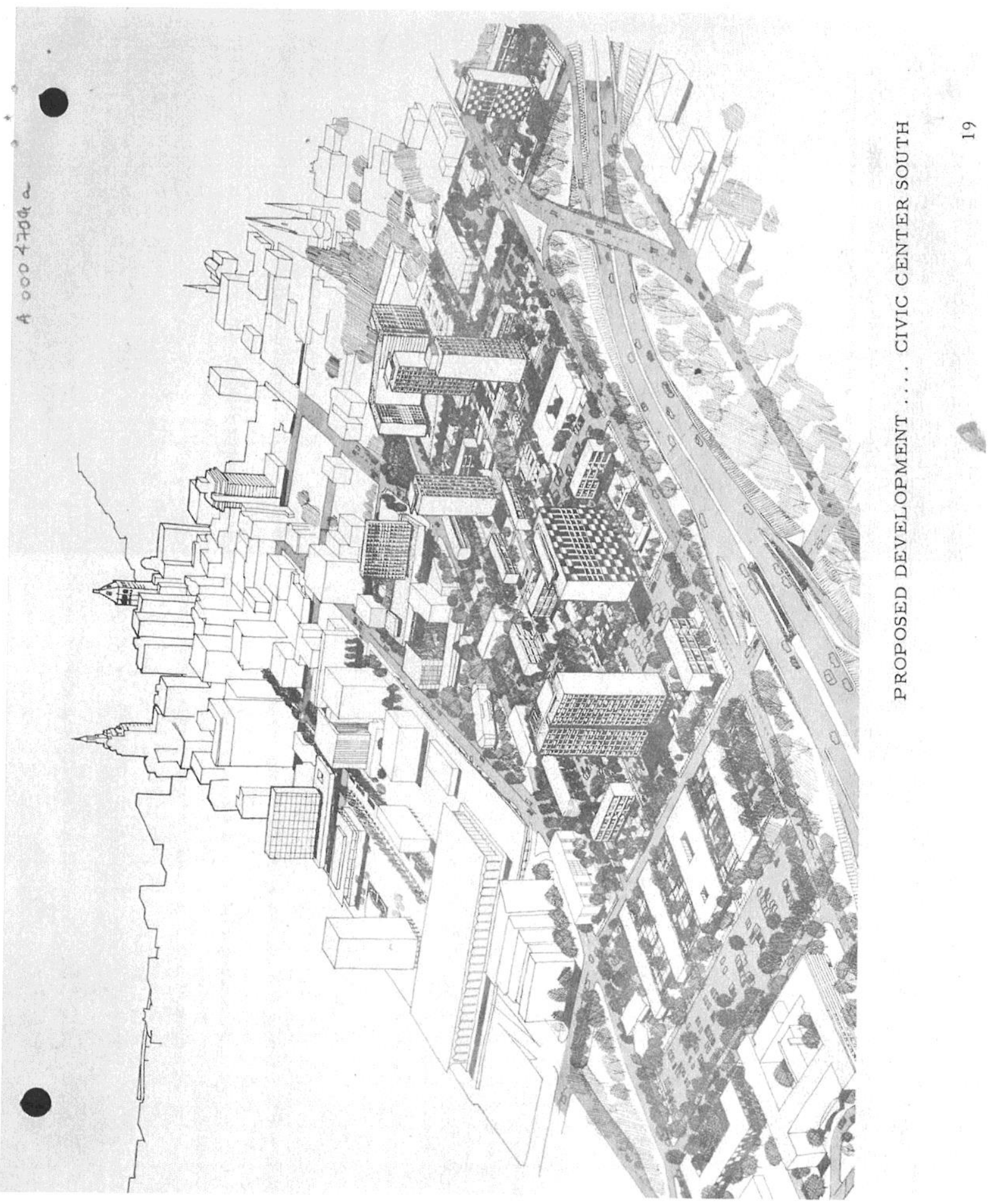




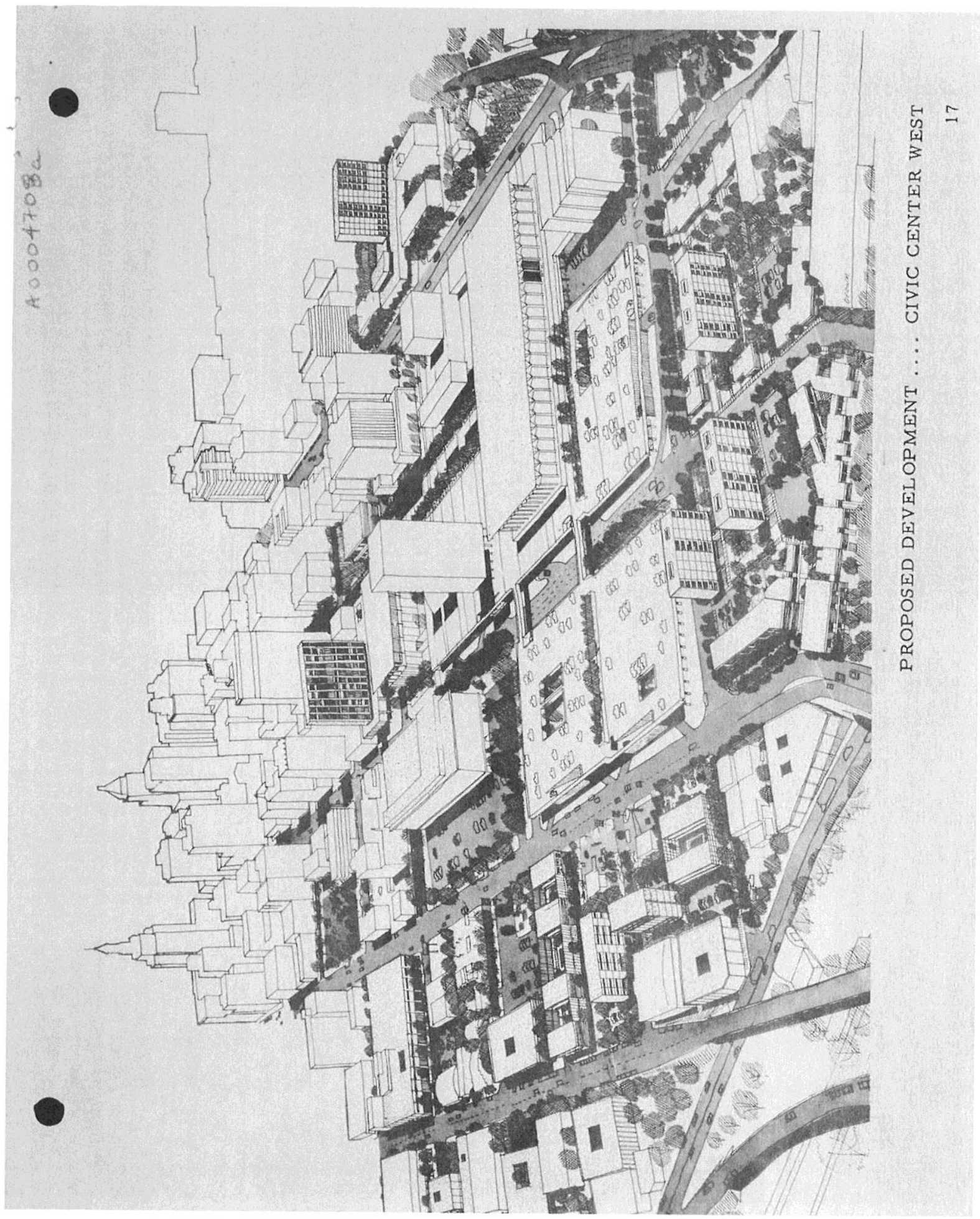




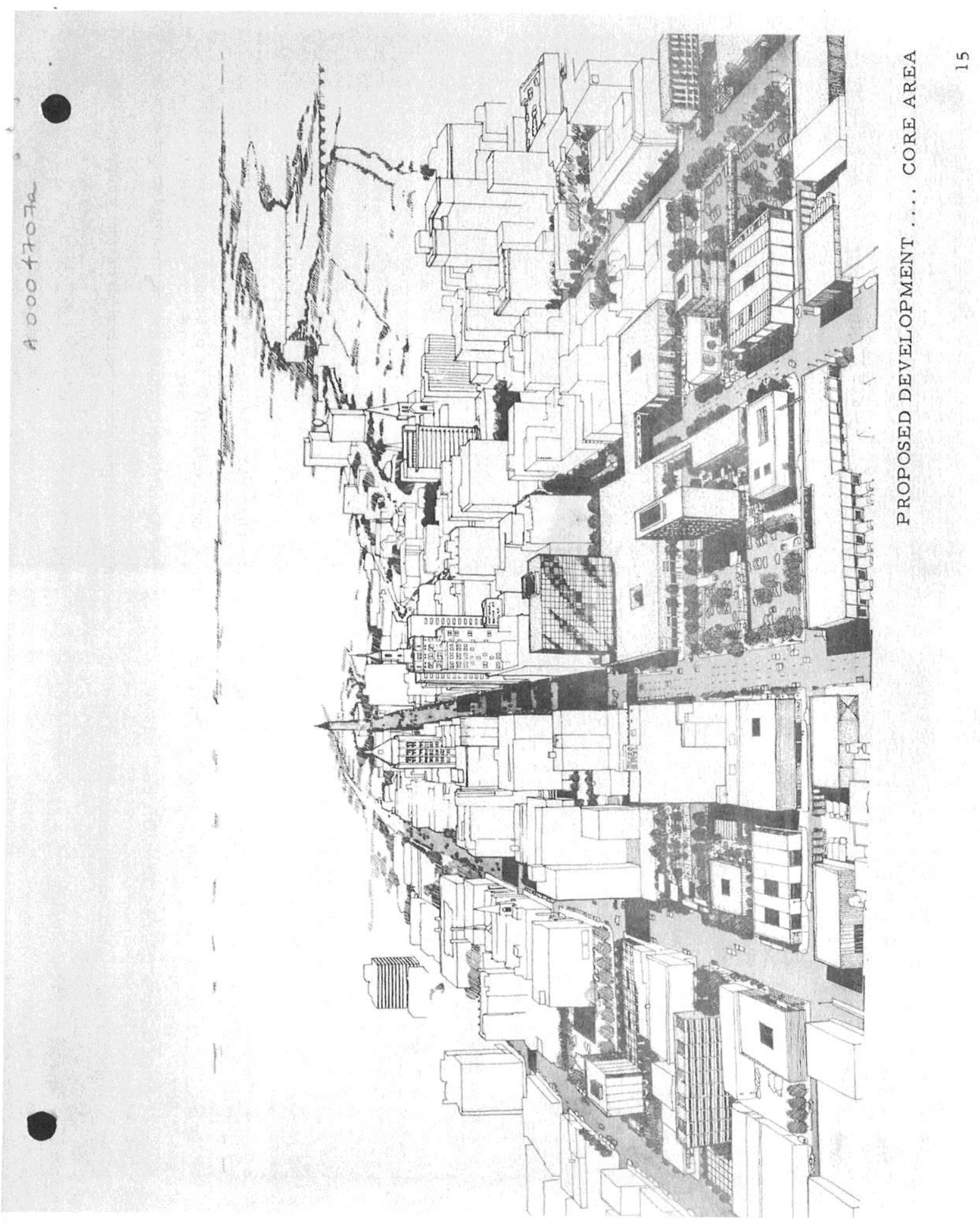


Maps from District 1 Plan (1980) by Tulsa Metropolitan Area Planning Commission
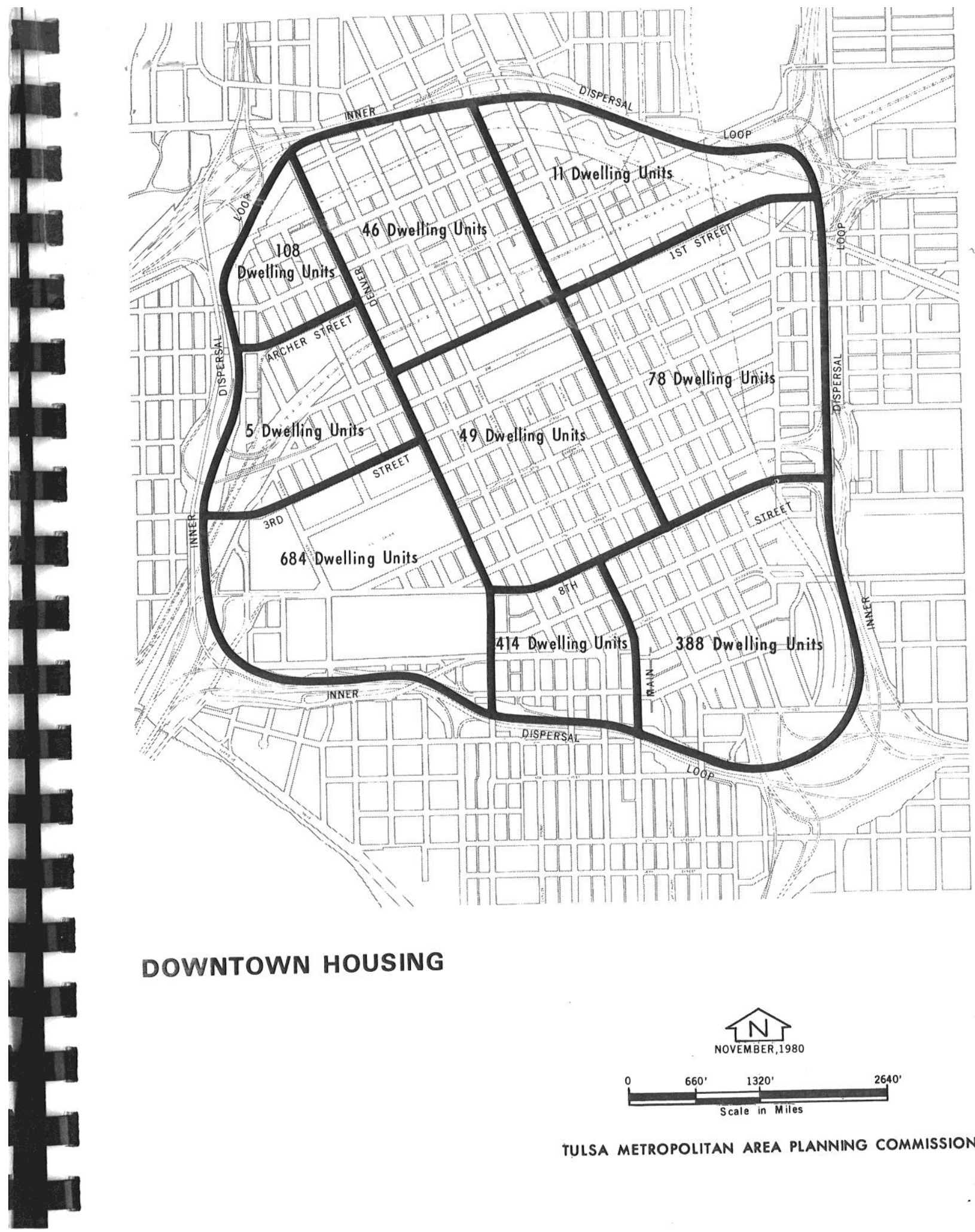

DOWNTOWN HOUSING

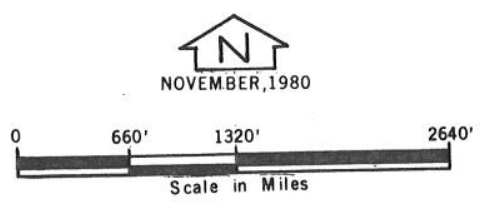

tULSA METROPOLITAN AREA PLANNING COMMISSION 


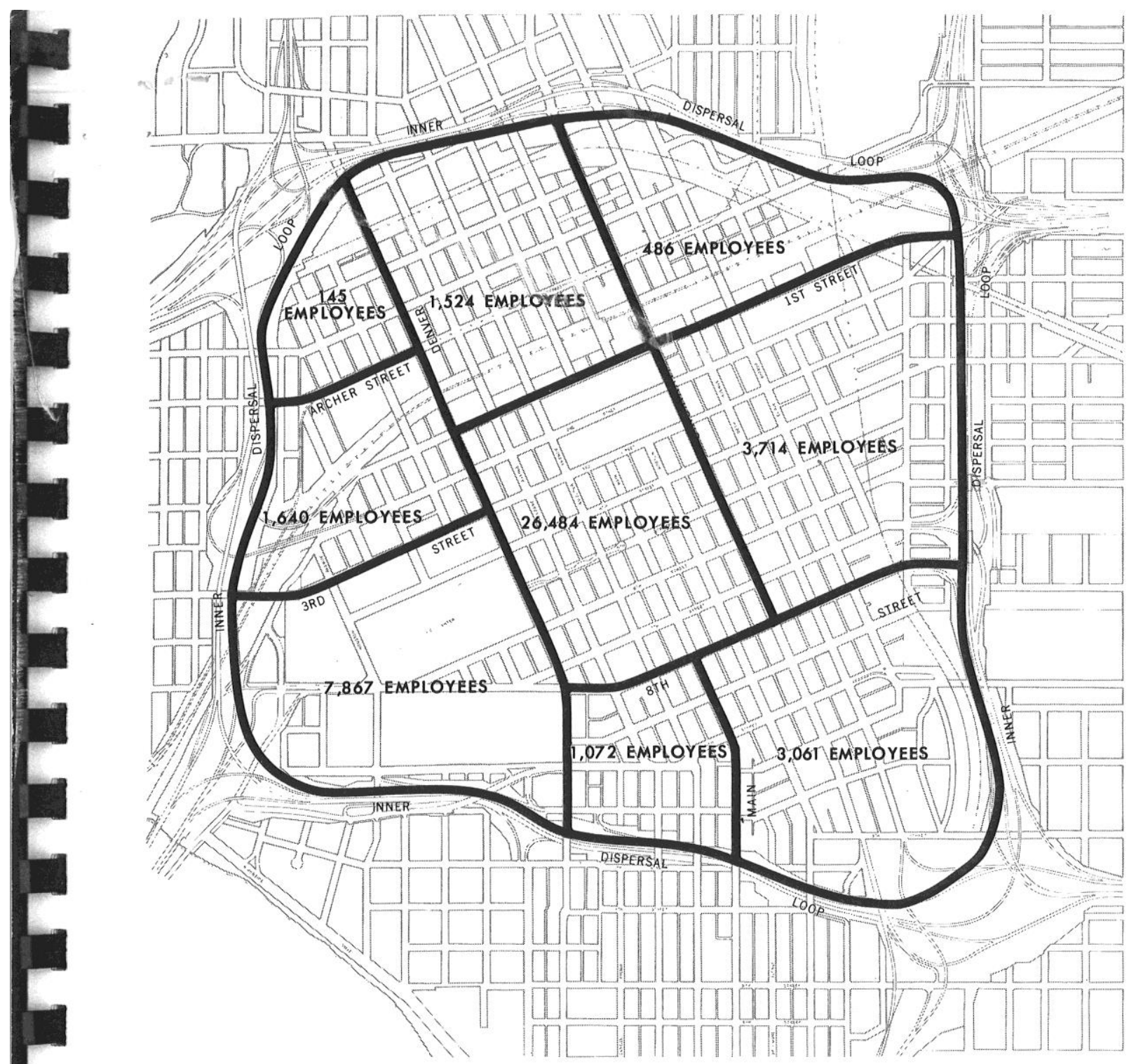

DOWNTOWN EMPLOYMENT

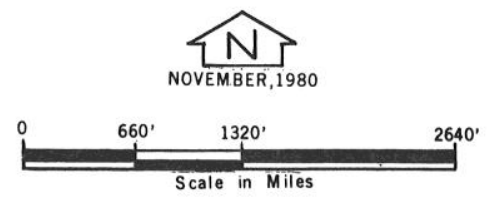

TULSA METROPOLITAN AREA PLANNING COMMISSION 


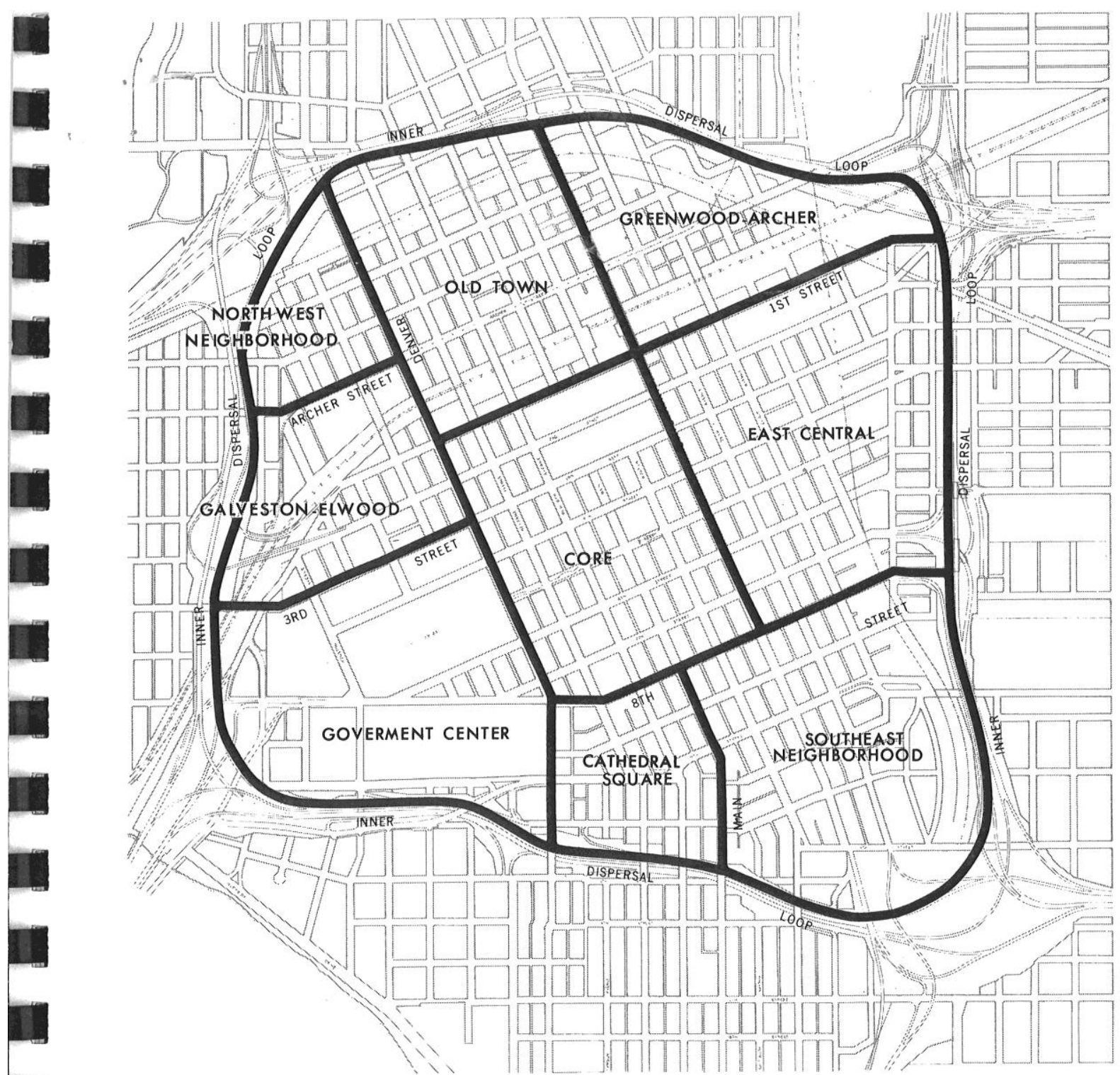

SUBAREA DESIGNATION MAP

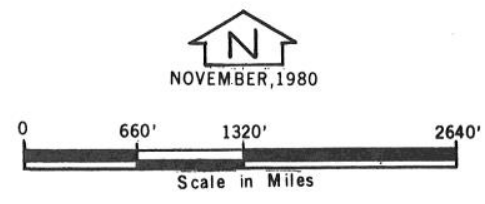

TULSA METROPOLITAN AREA PLANNING COMMISSION 
DOWNTOWN REVITALIZED, COMMUNITY ORGANIZED

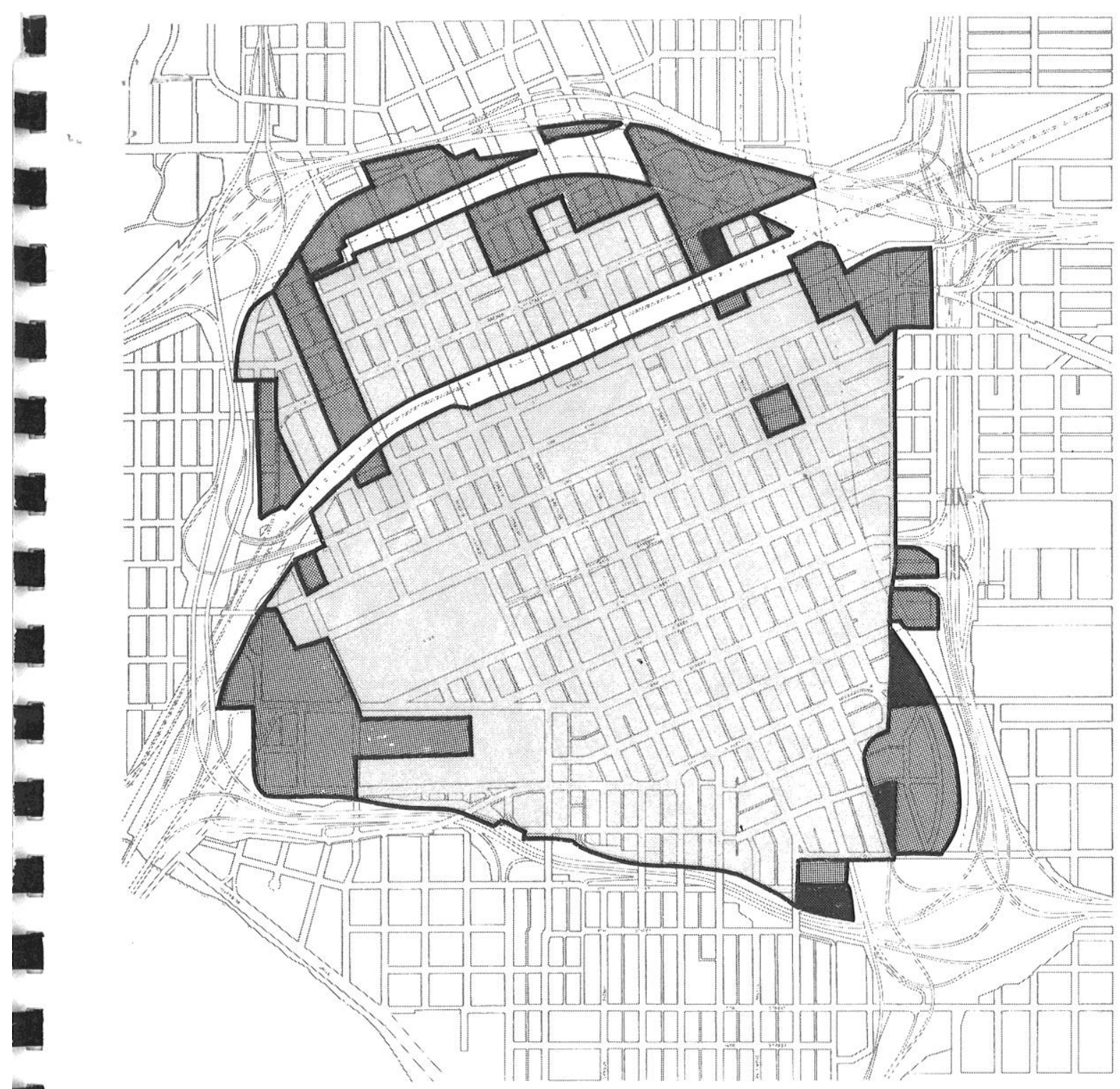

\section{INITIAL SITE DEVELOPMENT}
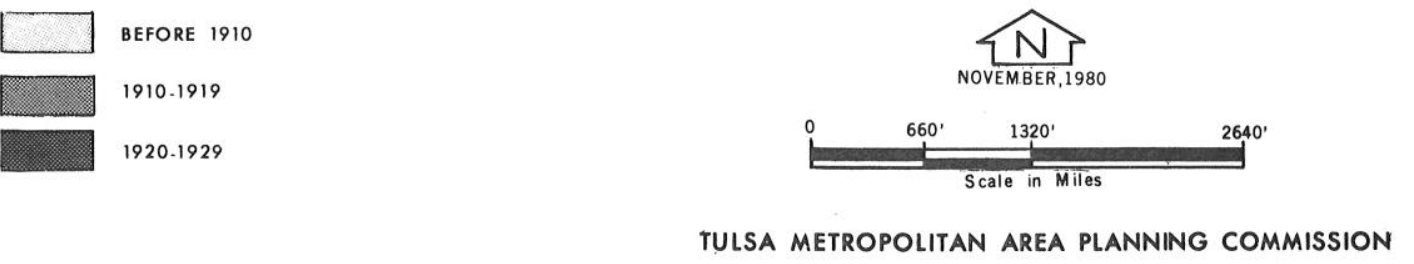

TULSA METROPOLITAN AREA PLANNING COMMISSION 
DOWNTOWN REVITALIZED, COMMUNITY ORGANIZED

\section{Map from Tulsa Model Cities (1971) by Tonne England}
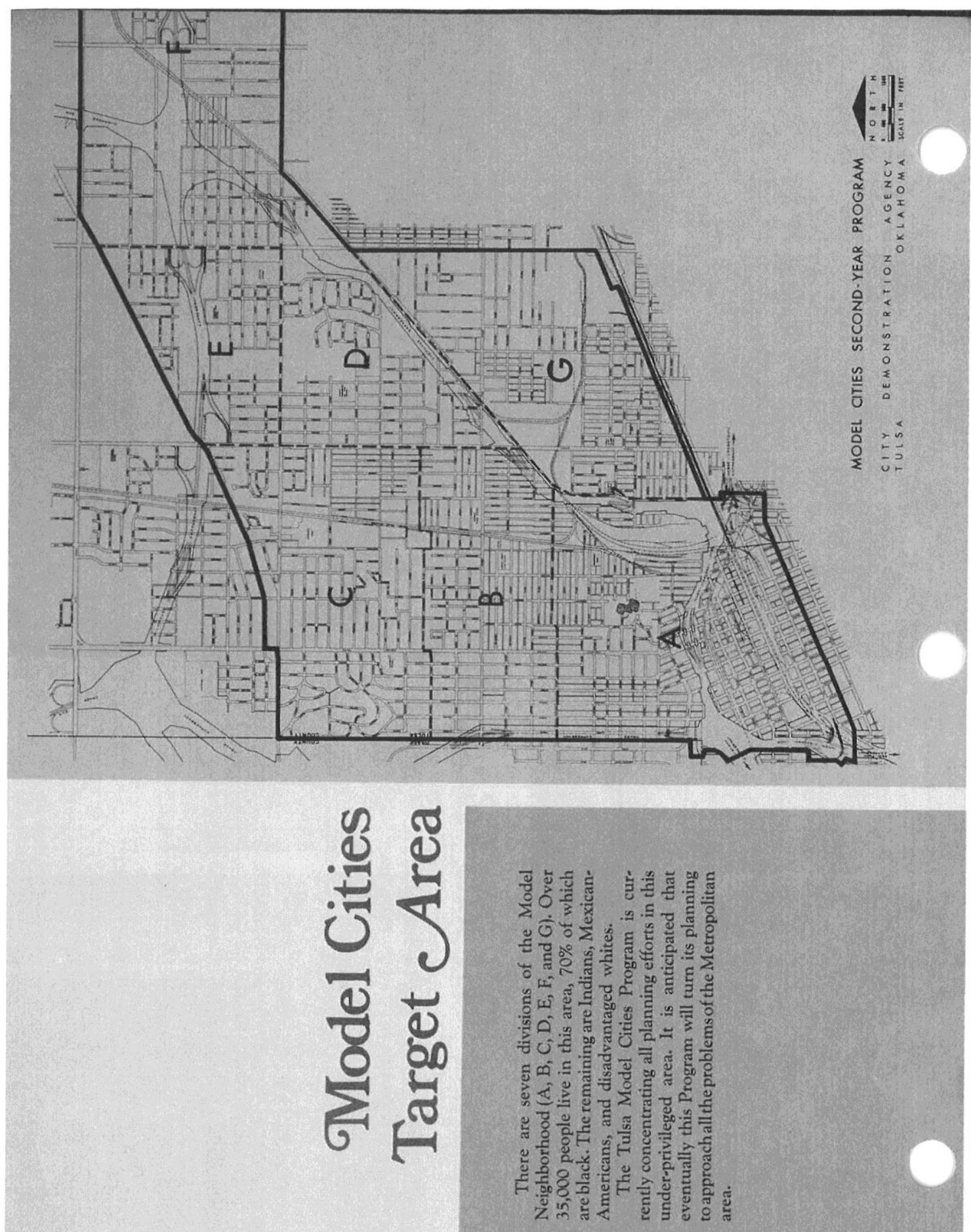
Tulsa Race Riot of 1921, Tulsa, Tulsa County, Oklahoma District Boundary

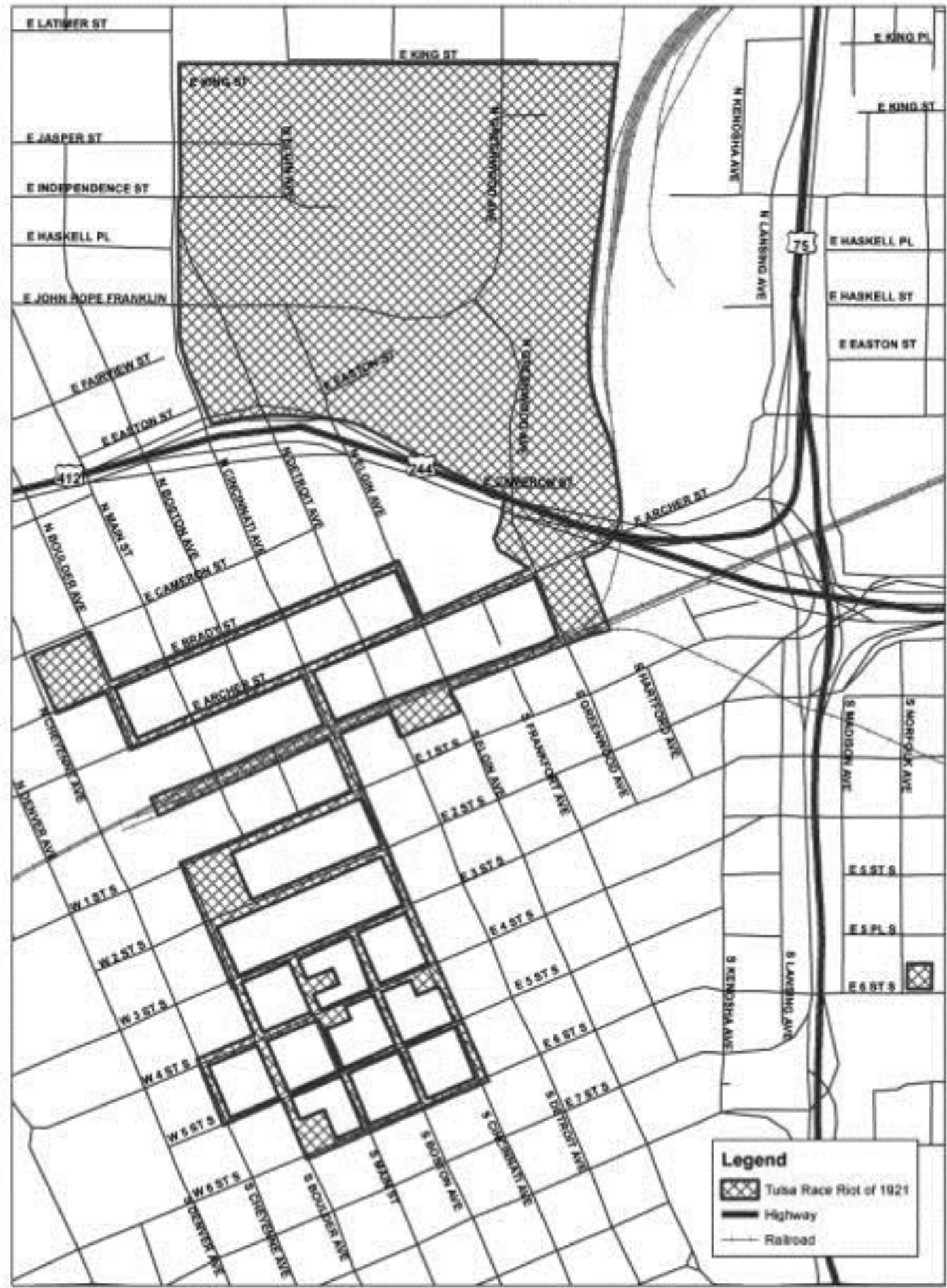

Map Source: OKJSHPO

Data Source: US Census Bureau, 2010 Tiger Lines

Wagoner County and Equivalent shapefiles

Retrieved April 20, 2012 from www. census.gov

Date of Production: June 27, 2012

0

0.25

0.5 Miles 
DOWNTOWN REVITALIZED, COMMUNITY ORGANIZED 